\title{
Living Polymerization of Chiral $O$-Carboxyanhydride of Mandelic Acid and Precise Stereoblock Copolymer Syntheses Using Highly Active OOO-Tridentate Bis(phenolate) Zinc Complexes
}

Jinxing Jiang, ${ }^{a}$ Yaqin cui, ${ }^{b}$ Zhaowei Jia, ${ }^{a}$ Xiaobo Pan, ${ }^{a}$ Jincai $W u^{*} a$

${ }^{a}$ State Key Laboratory of Applied Organic Chemistry (Lanzhou University), Key Laboratory of Nonferrous Metal Chemistry and Resources Utilization of Gansu Province, College of Chemistry and Chemical Engineering, Lanzhou University, Lanzhou 730000, People’s Republic of China.

${ }^{b}$ School of Chemical Engineering and Technology, Tianshui Normal University, Tianshui, Gansu 741001, People's Republic of China.

*Correspondence to:wujc@1zu.edu.cn.

This PDF file includes:

Experimental details

Figures. S1 to S66.

Tables S1 to S3.

References for SI reference citations 


\section{Experimental section}

\section{Materials}

Toluene, THF, and n-hexane were dried by refluxing with sodium and benzophenone, the latter serves as an indicator. $\mathrm{CH}_{2} \mathrm{Cl}_{2}$ and $\mathrm{BnOH}$ were distilled from $\mathrm{CaH}_{2} \cdot \mathrm{CDCl}_{3}$, toluene- $d_{8}$ and THF- $d_{8}$ were purchased from J\&K Scientific, Ltd. in Beijing and were dried over activated molecular sieves. ZnEt 2 , D-mandelic acid, L-mandelic acid and rac-mandelic acid were purchased from Energy Chemical and used as received, triphosgene was purchased from Beijing HWRK Chem Co. LTD. D-manOCA, L-manOCA and rac-manOCA, were synthesized according to the previous literature. ${ }^{1}$ All the other employed chemicals were purchased from the local reagent company and used as received without further purification unless otherwise stated.

\section{Measurements}

${ }^{1} \mathrm{H}$ NMR and ${ }^{13} \mathrm{C}$ NMR were recorded on Varian Mercury Plus $300 \mathrm{MHz}$ spectrometer, JNM-ECS 400 $\mathrm{MHz}$ and Varian INOVA $600 \mathrm{MHz} .{ }^{1} \mathrm{H}$ NMR chemical shifts are reported in ppm versus residual protons in deuterated solvents as follows: $\delta 7.26 \mathrm{ppm}$ for chloroform- $d, \delta 1.72$ and $3.58 \mathrm{ppm}$ for THF- $d_{8}$ and $\delta 2.08$ ppm for toluene- $d_{8} .{ }^{13} \mathrm{C}$ NMR chemical shifts are reported in ppm versus residual ${ }^{13} \mathrm{C}$ in the solvents: $\delta 77.0$ ppm for chloroform- $d, \delta 67.2$ and 25.3 ppm for THF- $d_{8}$.

The molecular weights $\left(M_{\mathrm{n}}\right)$ and the molecular mass distributions $Ð\left(M_{\mathrm{w}} / M_{\mathrm{n}}\right)$ of the polymer samples were measured by gel permeation chromatography (GPC) at $40{ }^{\circ} \mathrm{C}$ using THF as an eluent, an eluent flow rate of $1.0 \mathrm{~mL} / \mathrm{min}$, and narrow polystyrene standards as reference samples. The measurements were performed using a Shodex GPC KF-800 system that was equipped with a Shodex RI-201H detector, using Shodex-KF-803 and Shodex-KF-804 connected Styragel columns (400 - $400000 \mathrm{~kg} / \mathrm{mol})$. Poly(manOCA) is not corrected.

Matrix-Assisted Laser Desorption/ Ionization Time of Flight (MALDI-TOF) Mass Spectrometry conditions were as follows. Instrument type: Shimadzu MALDI-7090, Tuning Reflectron, Power 25, P.Ext at 5000.00 (bin 353), Ion Gate Blanking: 400.00, Laser Diameter: 100. The MALDI-TOF mass spectroscopic data were obtained using trans-2-[3-(4-tert-butylphenyl)-2-methyl-2-propenylidene]malonitrile (DCTB) as the matrix $(10 \mathrm{mg} / \mathrm{mL}$ in THF), and sodium trifluoroacetate as the cationization agent $(10 \mathrm{mg} / \mathrm{mL}$ in THF). Samples were dissolved in THF $(10 \mathrm{mg} / \mathrm{mL})$. Solutions of matrix and salt were mixed in a volume ratio of 4: 1 . Then the mixed solution $(0.5 \mu \mathrm{L})$, samples $(0.5 \mu \mathrm{L})$ and mixed solution $(0.5 \mu \mathrm{L})$ was hand-spotted on a stainless steel MALDI target in order, which allowed to be dried completely.

Differential scanning calorimetry (DSC) measurements, using 5-10 mg of material, DSC experiments were performed on a NETZSCH STA 449F3 instrument with a heat $\left(40-220^{\circ} \mathrm{C}\right) / \operatorname{cool}\left(220-40{ }^{\circ} \mathrm{C}\right) /$ heat $(40-220$ ${ }^{\circ} \mathrm{C}$ ) cycle at a heating rate of $10{ }^{\circ} \mathrm{C} \mathrm{min}^{-1}$ and cooling rate of $10{ }^{\circ} \mathrm{C} / \mathrm{min}$ under $\mathrm{N}_{2}$ atmosphere. All $T_{\mathrm{m}}, T_{\mathrm{c}}$ and $\Delta H_{\mathrm{m}}$ values were obtained from a first heating scan, $T_{\mathrm{g}}$ values were obtained from a second heating scan.

Thermal gravimetric analyzer (TGA): using 5-10 $\mathrm{mg}$ of material, TGA experiments were performed on a NETZSCH STA 449F3 instrument, with a heat $\left(40-450{ }^{\circ} \mathrm{C}\right)$ at a rate of $10{ }^{\circ} \mathrm{C} \mathrm{min}^{-1}$ under $\mathrm{N}_{2}$ atmosphere. Decomposition temperatures $\left(T_{\mathrm{d}}\right.$, defined by the temperature of $5 \%$ weight loss) and maximum rate decomposition temperatures $\left(T_{\max }\right)$ of the polymers were measured. 
Method for preparing DSC and TGA samples. These samples were prepared by the following method: about $40 \mathrm{mg}$ polymer was dissolved in $2 \mathrm{~mL}$ of DCM, stirred slowly, then $4 \mathrm{~mL}$ of methanol was added dropwise, the solution formed two phases. After stirring for several hours, a white powder was precipitated. After Stop stirring for 30 minutes, the filtrate was poured out and the sample was vacuum dried.

X-ray powder diffraction (XRD) patterns of the polymers were obtained with a SHIMADZU XRD 6100 with $\mathrm{Cu}$ radiation over the $2 \theta$ range of $5-40^{\circ}$ with a scan speed of $0.3333^{\circ} / \mathrm{s}$ and a step size of $0.01^{\circ}$ at room temperature.

\section{General procedure for polymerization of manOCA.}

A typical polymerization procedure is illustrated by the synthesis of Poly(L-manOCA) with a 1:1:100 ratio of $[\mathrm{Zn}]_{0} /[\mathrm{BnOH}]_{0} /[\mathrm{Monomer}]_{0}$ (Table 1 , entry 1). L-manOCA $(0.178 \mathrm{~g}, 1.0 \mathrm{mmol})$ was added into a $2 \mathrm{~mL}$ THF solution of $0.01 \mathrm{mmol}$ of 1 and $0.01 \mathrm{mmol} \mathrm{BnOH}$. The solution was rapidly stirred at room temperature for $15 \mathrm{~min}$. An aliquot was withdrawn to determine monomer conversion by ${ }^{1} \mathrm{H}$ NMR spectroscopy. The polymer was precipitated via adding $n$-hexane $(2 \mathrm{~mL})$. A white solid was obtained by recrystallization from a $\mathrm{CH}_{2} \mathrm{Cl}_{2} /$ hexane mixed solvent and dried under vacuum.

Poly(L-manOCA): ${ }^{1} \mathrm{H}$ NMR (400 MHz, $\left.\mathrm{CDCl}_{3}\right): \delta 7.14-7.40(\mathrm{~m}, 5 \mathrm{H}), 5.95(\mathrm{~s}, 1 \mathrm{H}) .{ }^{13} \mathrm{C}$ NMR $(100 \mathrm{MHz}$, $\left.\mathrm{CDCl}_{3}\right): \delta 166.75,132.25,129.35,128.64,127.79,74.70$.

\section{Synthesis of manOCAs.}

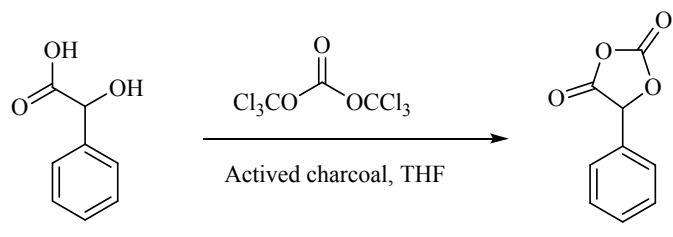

According to literature procedures. ${ }^{1}$ To a solution of mandelic acid $(100.0 \mathrm{mmol}, 15.2 \mathrm{~g})$ and activated charcoal $(\sim 1.3 \mathrm{~g})$ in anhydrous THF $(100 \mathrm{~mL})$, the solution of triphosgene $(90.0 \mathrm{mmol}, 26.7 \mathrm{~g})$ in $50 \mathrm{~mL}$ THF was added at $0{ }^{\circ} \mathrm{C}$. The reaction mixture was stirred for 12 hours at room temperature, then filtered through celite, the filtrate was removed under reduced pressure and trapped with liquid nitrogen. *** CAUTION: The latter solution was carefully neutralized at $0{ }^{\circ} \mathrm{C}$ with aqueous ammonia. *** Recrystallization from dry DCM/n-hexane at $-10{ }^{\circ} \mathrm{C}$ three times afforded colorless crystals. Yield, $76 \%{ }^{1} \mathrm{H}$ NMR ( $\left.\mathrm{CDCl}_{3}, 400 \mathrm{MHz}\right): \delta 6.02(\mathrm{~s}, 1 \mathrm{H}), 7.40-7.46(\mathrm{~m}, 5 \mathrm{H}) ;{ }^{13} \mathrm{C} \mathrm{NMR}\left(100 \mathrm{MHz}, \mathrm{CDCl}_{3}\right): \delta 80.40,126.11$, $129.22,129.53,130.78,147.96,165.28$.

\section{Synthesis of ligands.}

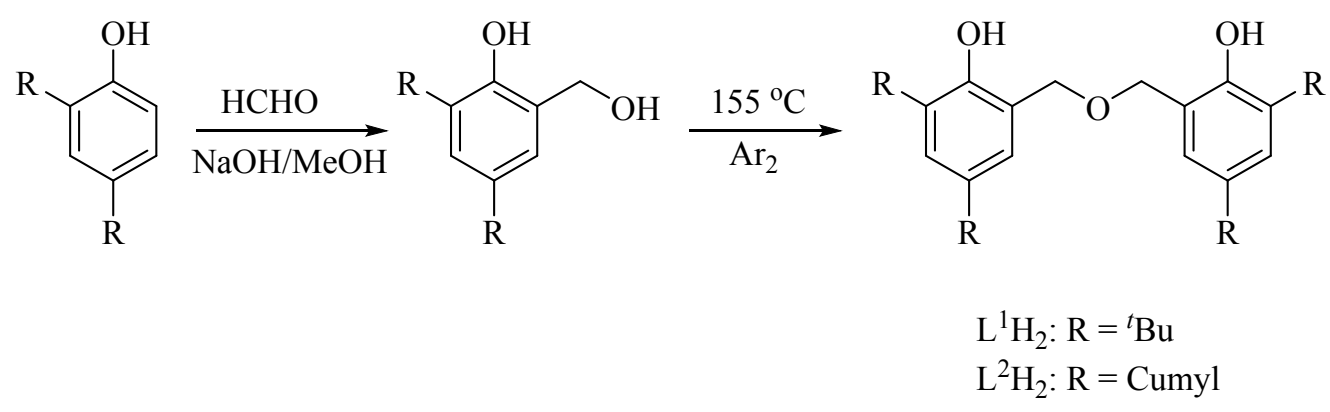


<smiles>COC(=O)C(c1cc(C(C)(C)C)cc(CO)c1O)C(C)(C)C</smiles>

The synthesis procedure of 2,4-Di-tert-butyl-6-hydroxymethylphenol. ${ }^{2}$

To a solution of 2,4-di-tert-butylphenol (10.3 g, $50.0 \mathrm{mmol})$ in methanol (60 mL), NaOH (2.2 g, $55.0 \mathrm{mmol})$ was added, this solution was stirred at room temperature for $30 \mathrm{~min}$. Then the aqueous formaldehyde $(36 \%$ sol., $12.5 \mathrm{~mL}, 160.0 \mathrm{mmol}$ ) was added to the reaction mixture which was stirred at room temperature for an additional $26 \mathrm{~h}$. Then the reaction mixture was poured over $300 \mathrm{~mL}$ water, acidified with $36 \% \mathrm{HCl}$ to $\mathrm{pH} 2-$ 3 , and extracted with ethyl acetate $(3 \times 100 \mathrm{~mL})$. The organic extract was dried over $\mathrm{Na}_{2} \mathrm{SO}_{4}$, filtrated, and evaporated to afford the crude product, and recrystallized with n-hexane to obtained colorless crystals $8.9 \mathrm{~g}$, yield 75\%. ${ }^{1} \mathrm{H}$ NMR (300 MHz, Chloroform- $d$ ) $\delta 7.54(\mathrm{~s}, 1 \mathrm{H}), 7.28(\mathrm{~d}, J=2.5 \mathrm{~Hz}, 1 \mathrm{H}), 6.90(\mathrm{~d}, J=2.5 \mathrm{~Hz}$, $1 \mathrm{H}), 4.85(\mathrm{~d}, J=5.9 \mathrm{~Hz}, 2 \mathrm{H}), 2.04(\mathrm{t}, J=5.9 \mathrm{~Hz}, 1 \mathrm{H}), 1.43(\mathrm{~s}, 10 \mathrm{H}), 1.28(\mathrm{~s}, 9 \mathrm{H})$.<smiles>C[Al]c1ccc(O)c(N=CC(C)C=O)c1</smiles>

The synthesis procedure of 2,4-Di-cumyl-6-hydroxymethylphenol. ${ }^{3}$ To a solution of 2,4-di-cumylphenol $(6.6 \mathrm{~g}, 20.0 \mathrm{mmol})$ in methanol $(30 \mathrm{~mL}), \mathrm{NaOH}(1.8 \mathrm{~g}, 45.0 \mathrm{mmol})$ was added and this solution was stirred at room temperature for $30 \mathrm{~min}$. Aqueous formaldehyde $(36 \%$ sol., $5 \mathrm{~mL}, 60.0 \mathrm{mmol})$ was added to the reaction mixture and stirred at room temperature for an additional $26 \mathrm{~h}$. Then the reaction mixture was poured over $300 \mathrm{~mL}$ water, acidified with $36 \% \mathrm{HCl}$ to $\mathrm{pH} 2-3$, and extracted with ethyl acetate $(3 \times 100$ $\mathrm{mL}$ ). The organic extract was dried over $\mathrm{Na}_{2} \mathrm{SO}_{4}$, filtrated, and evaporated to afford the crude product. This crude product was recrystallized with n-hexane to afford white solid $5.8 \mathrm{~g}$, yield $81 \%$. ${ }^{1} \mathrm{H} \mathrm{NMR}(600 \mathrm{MHz}$, Chloroform- $d$ ) $\delta 7.37-7.15(\mathrm{~m}, 12 \mathrm{H}), 6.92(\mathrm{~d}, J=2.0 \mathrm{~Hz}, 1 \mathrm{H}), 5.65(\mathrm{~s}, 1 \mathrm{H}), 4.60(\mathrm{~d}, J=6.1 \mathrm{~Hz}, 2 \mathrm{H}), 2.14$ $(\mathrm{t}, J=6.1 \mathrm{~Hz}, 1 \mathrm{H}), 1.71(\mathrm{~s}, 6 \mathrm{H}), 1.63(\mathrm{~s}, 6 \mathrm{H})$.<smiles>CC(C)(C)c1cc(Br)cc(COCc2cc(C(=O)c3ccccc3)cc(Br)c2O)c1O</smiles>

$\mathrm{L}^{1} \mathrm{H}_{2}$

The synthesis procedure of $\mathrm{L}^{1} \mathrm{H}_{2} \cdot{ }^{4}$

Dry 2,4-di-tert-butyl-6-(hydroxymethyl)phenol $(2.4 \mathrm{~g}, 10.1 \mathrm{mmol})$ was heated slowly to $155{ }^{\circ} \mathrm{C}$ for $5 \mathrm{~h}$ under argon atmosphere. The crude product is recrystallized using methanol as a solvent at $-30{ }^{\circ} \mathrm{C}$. White solid precipitates can be obtained after filterization and dried in vacuo, yielding $1.1 \mathrm{~g}(2.4 \mathrm{mmol}, 48 \%) .{ }^{1} \mathrm{H}$ 
NMR (400 MHz, Chloroform- $d$ ) $\delta 7.32(\mathrm{~d}, J=2.4 \mathrm{~Hz}, 2 \mathrm{H}), 6.99(\mathrm{~s}, 2 \mathrm{H}), 6.88(\mathrm{~d}, J=2.4 \mathrm{~Hz}, 2 \mathrm{H}), 4.73$ (s, 4H), $1.43(\mathrm{~s}, 18 \mathrm{H}), 1.29(\mathrm{~s}, 18 \mathrm{H}) .{ }^{13} \mathrm{C}$ NMR $(75 \mathrm{MHz}$, Chloroform- $d$ ) $\delta 152.78,141.83,136.33,124.59$, $123.91,120.72,71.35,34.91,34.20,31.58,29.63$.

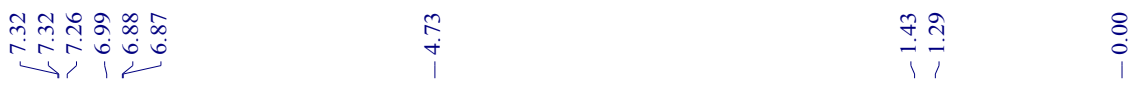
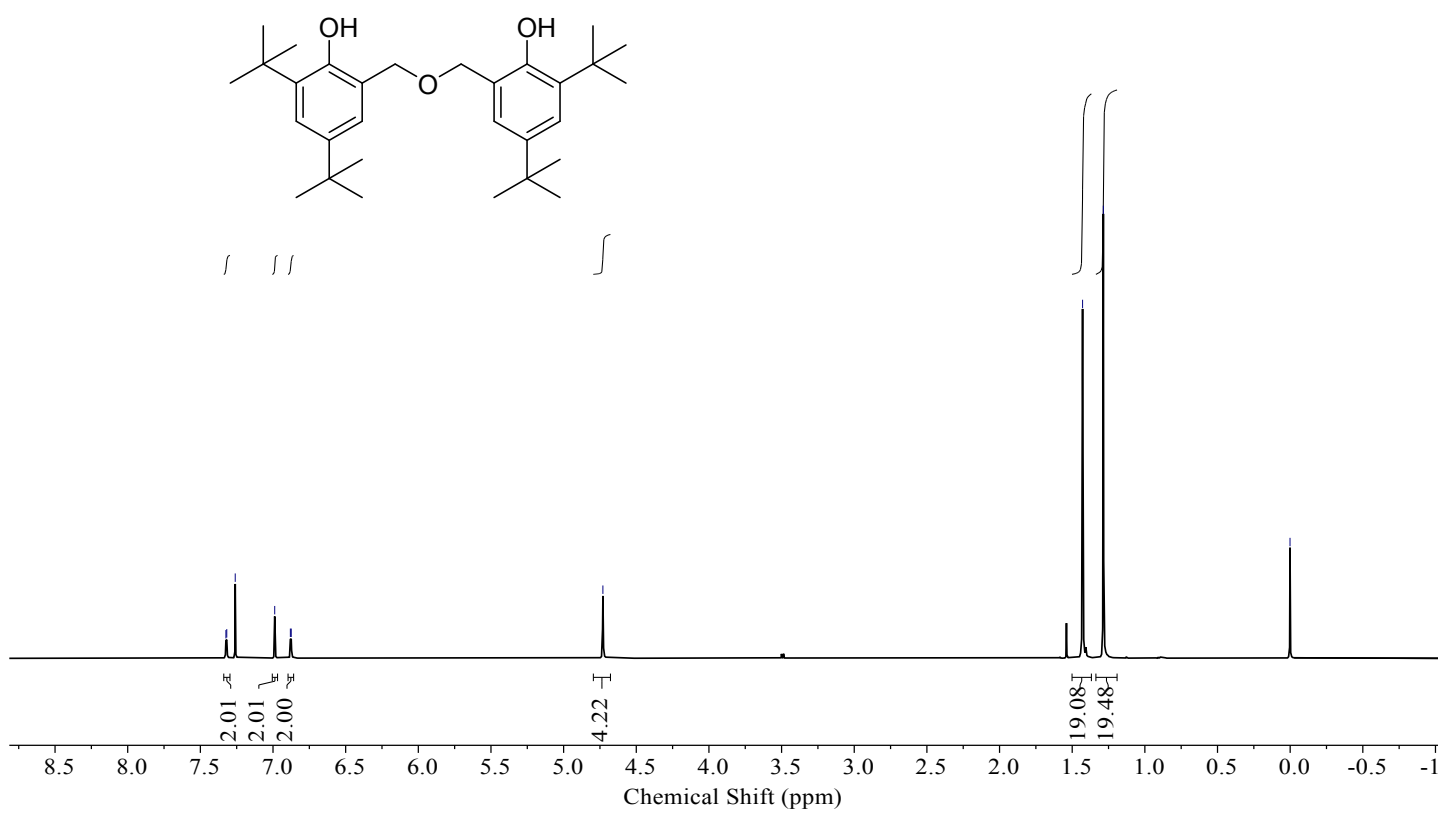

Figure $\mathrm{S} 1$. The ${ }^{1} \mathrm{H}$ NMR spectrum of $\mathrm{L}^{1} \mathrm{H}_{2}\left(300 \mathrm{MHz}, \mathrm{CDCl}_{3}\right)$.

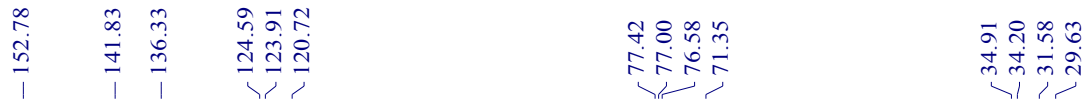
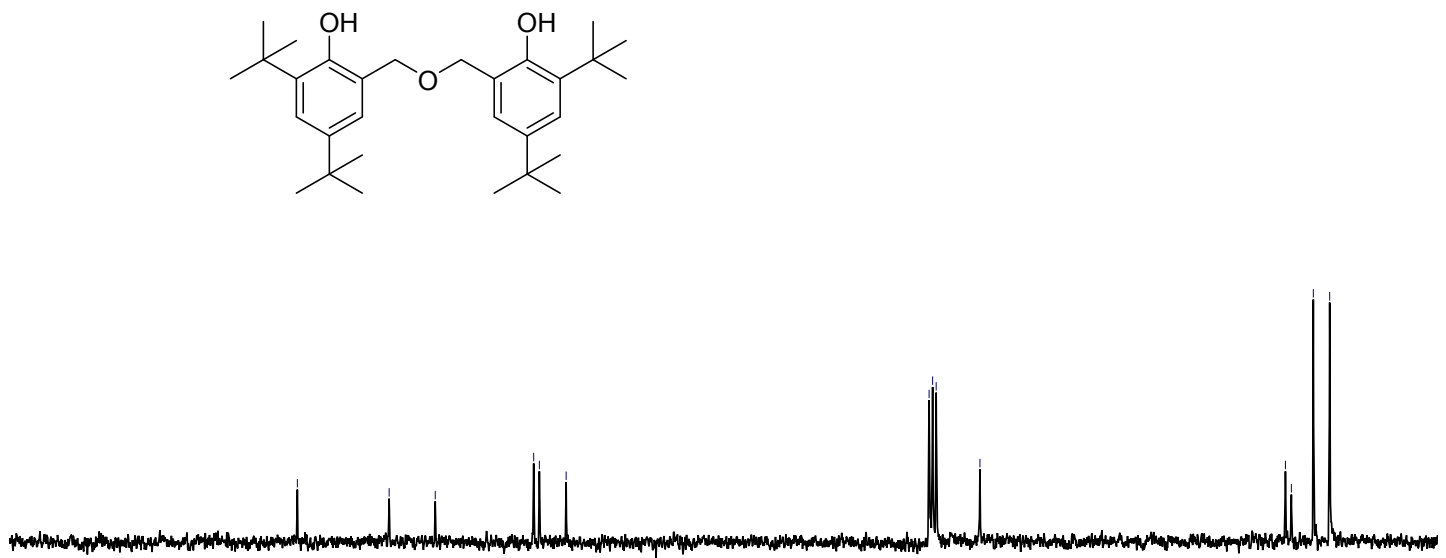

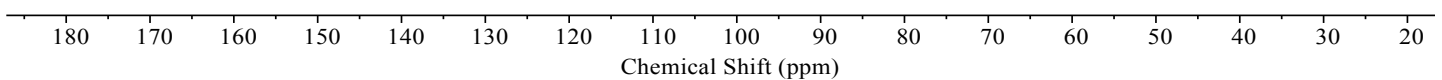

Figure $\mathrm{S} 2$. The ${ }^{13} \mathrm{C} \mathrm{NMR}$ spectrum of $\mathrm{L}^{1} \mathrm{H}_{2}\left(75 \mathrm{MHz}, \mathrm{CDCl}_{3}\right)$. 


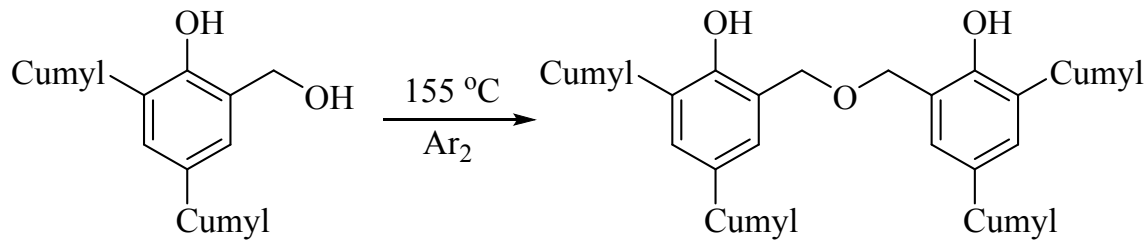

$\mathrm{L}^{2} \mathrm{H}_{2}$

The synthetic steps are similar to $\mathrm{L}^{1} \mathrm{H}_{2}$.

Dry 2,4-di-cumyl-6-(hydroxymethyl)phenol $(3.6 \mathrm{~g}, 10.0 \mathrm{mmol})$ was heated slowly to $155{ }^{\circ} \mathrm{C}$ for $5 \mathrm{~h}$ under argon atmosphere. The reaction finally becomes a solid. The crude product is recrystallized from methanol. The white solid was filtered and dried in vacuo, yielding $2.8 \mathrm{~g}(4.0 \mathrm{mmol}, 80 \%) .{ }^{1} \mathrm{H} \mathrm{NMR}(300 \mathrm{MHz}$, Chloroform- $d$ ) $\delta 7.40-6.69(\mathrm{~m}, 24 \mathrm{H}), 5.91(\mathrm{~s}, 2 \mathrm{H}), 4.42(\mathrm{~s}, 4 \mathrm{H}), 1.66(\mathrm{~s}, 12 \mathrm{H}), 1.57(\mathrm{~s}, 12 \mathrm{H}) .{ }^{13} \mathrm{C}$ NMR $(75$ MHz, Chloroform-d) $\delta 151.41,150.95,149.70,141.40,135.16,128.37,127.90$, 126.72 , 125.95 , $125.92,125.72,125.57,125.47,122.98,70.76,42.50,41.96,31.03,29.61$.

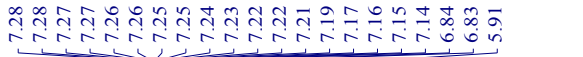
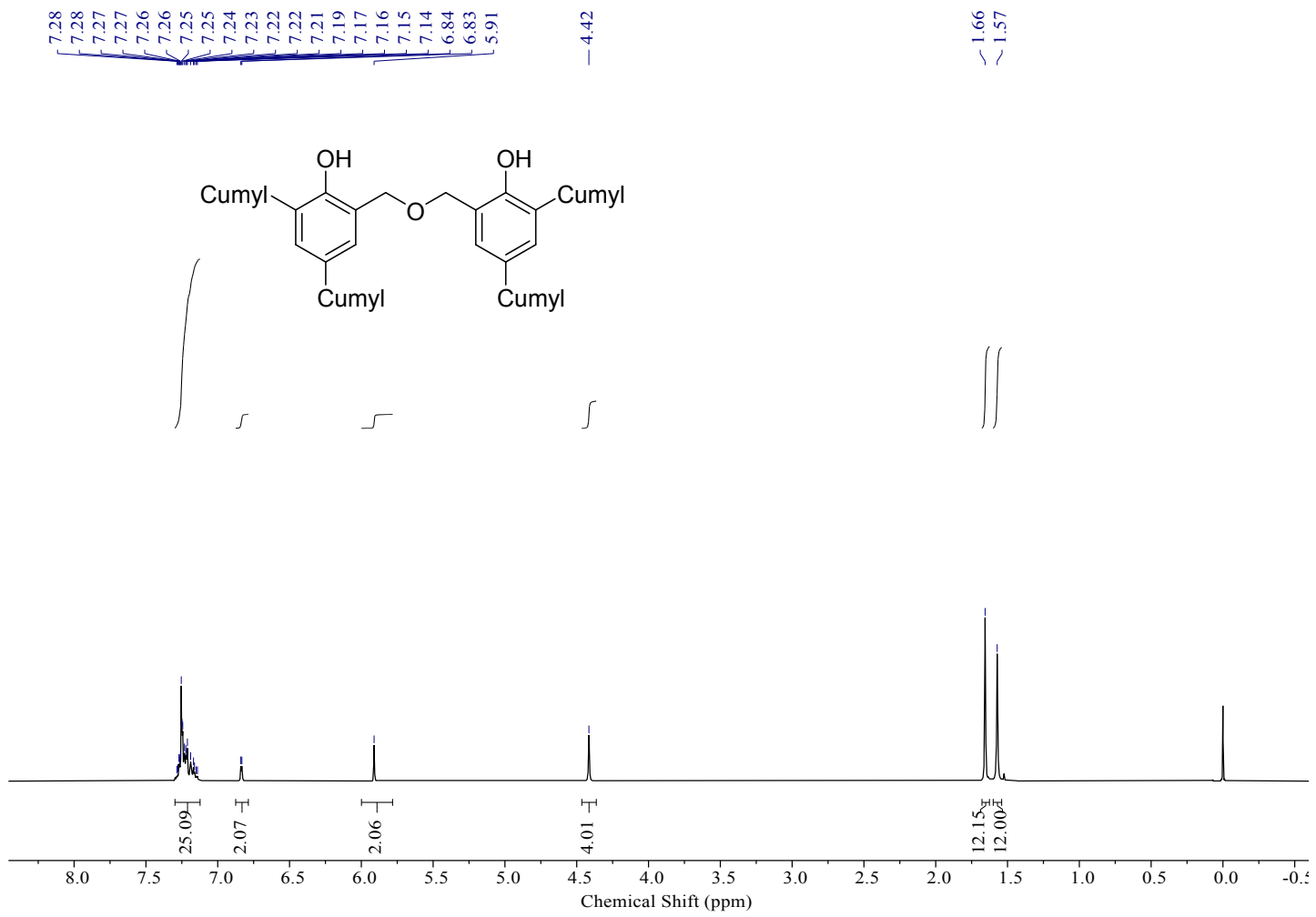

Figure S3. The ${ }^{1} \mathrm{H}$ NMR spectrum of $\mathrm{L}^{2} \mathrm{H}_{2}\left(300 \mathrm{MHz}, \mathrm{CDCl}_{3}\right)$. 
<smiles>CCc1cc(CC)c(O)c(COCc2cc(CC)cc(CC)c2O)c1</smiles>

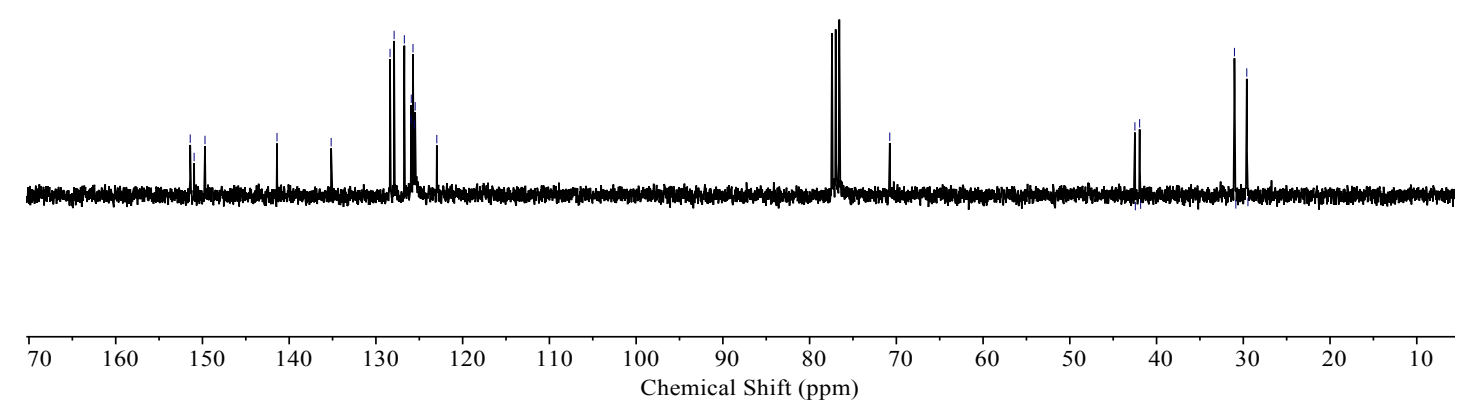

Figure S4. The ${ }^{13} \mathrm{C}$ NMR spectrum of $\mathrm{L}^{2} \mathrm{H}_{2}\left(75 \mathrm{MHz}, \mathrm{CDCl}_{3}\right)$.

\section{Synthesis of complexes.}
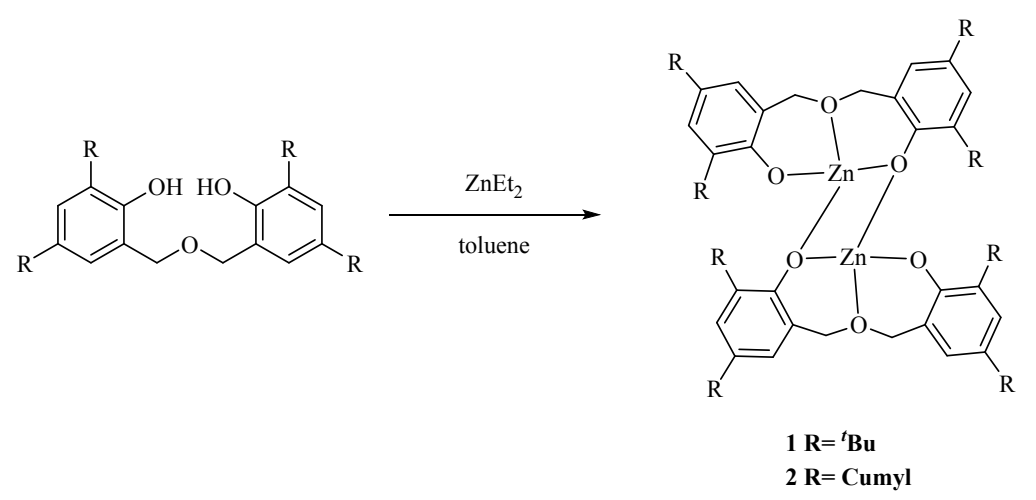

The synthesis procedure of complex 1.5

To an ice-cold solution of ligands $(1.0 \mathrm{mmol})$ in toluene $(20 \mathrm{~mL})$ was slowly added a $\mathrm{ZnEt}_{2}(1.1 \mathrm{~mL}, 1.0 \mathrm{M}$ in hexane, $1.1 \mathrm{mmol}$ ) solution. The mixture was stirred for $12 \mathrm{~h}$ and a large amount of precipitation appears, precipiates can obtained by filiterization and was washed the with cold toluene, and the white solid powder was obtained.

Complex 1, yield $0.4 \mathrm{~g}(77 \%) .{ }^{1} \mathrm{H}$ NMR (600 MHz, Chloroform-d) $\delta 7.25(\mathrm{~s}, 2 \mathrm{H}), 7.08(\mathrm{~s}, 2 \mathrm{H}), 7.02(\mathrm{~s}, 2 \mathrm{H})$, $6.80(\mathrm{~s}, 2 \mathrm{H}), 5.56(\mathrm{~d}, J=13.1 \mathrm{~Hz}, 2 \mathrm{H}), 4.97$ (d, $J=9.8 \mathrm{~Hz}, 2 \mathrm{H}), 4.59$ (d, $J=13.1 \mathrm{~Hz}, 2 \mathrm{H}), 4.23(\mathrm{~d}, J=9.8$ $\mathrm{Hz}, 2 \mathrm{H}), 1.27(\mathrm{~s}, 18 \mathrm{H}), 1.21(\mathrm{~s}, 18 \mathrm{H}) 1.20(\mathrm{~s}, 18 \mathrm{H}), 1.08(\mathrm{~s}, 18 \mathrm{H}) .{ }^{13} \mathrm{C}$ NMR $(151 \mathrm{MHz}$, Chloroform- $d) \delta$ $161.26,157.08,142.60,139.57,138.29,137.88,125.86,125.62,125.10,124.90,124.15,122.18,75.00$, $74.31,34.97,34.77,34.19,33.90,31.66,31.54,30.14,29.15$.

${ }^{1} \mathrm{H}$ NMR $\left(600 \mathrm{MHz}, \mathrm{THF}-d_{8}\right) \delta 7.14(\mathrm{~s}, 2 \mathrm{H}), 6.83(\mathrm{~s}, 2 \mathrm{H}), 4.50(\mathrm{~s}, 4 \mathrm{H}), 1.44(\mathrm{~s}, 18 \mathrm{H}), 1.24(\mathrm{~s}, 18 \mathrm{H}) .{ }^{13} \mathrm{C}$ NMR $\left(151 \mathrm{MHz}, \mathrm{THF}-d_{8}\right) \delta 163.27,136.66,134.44,124.21,123.33,122.70,73.90,34.79,33.39,31.26$, 29.16 . 


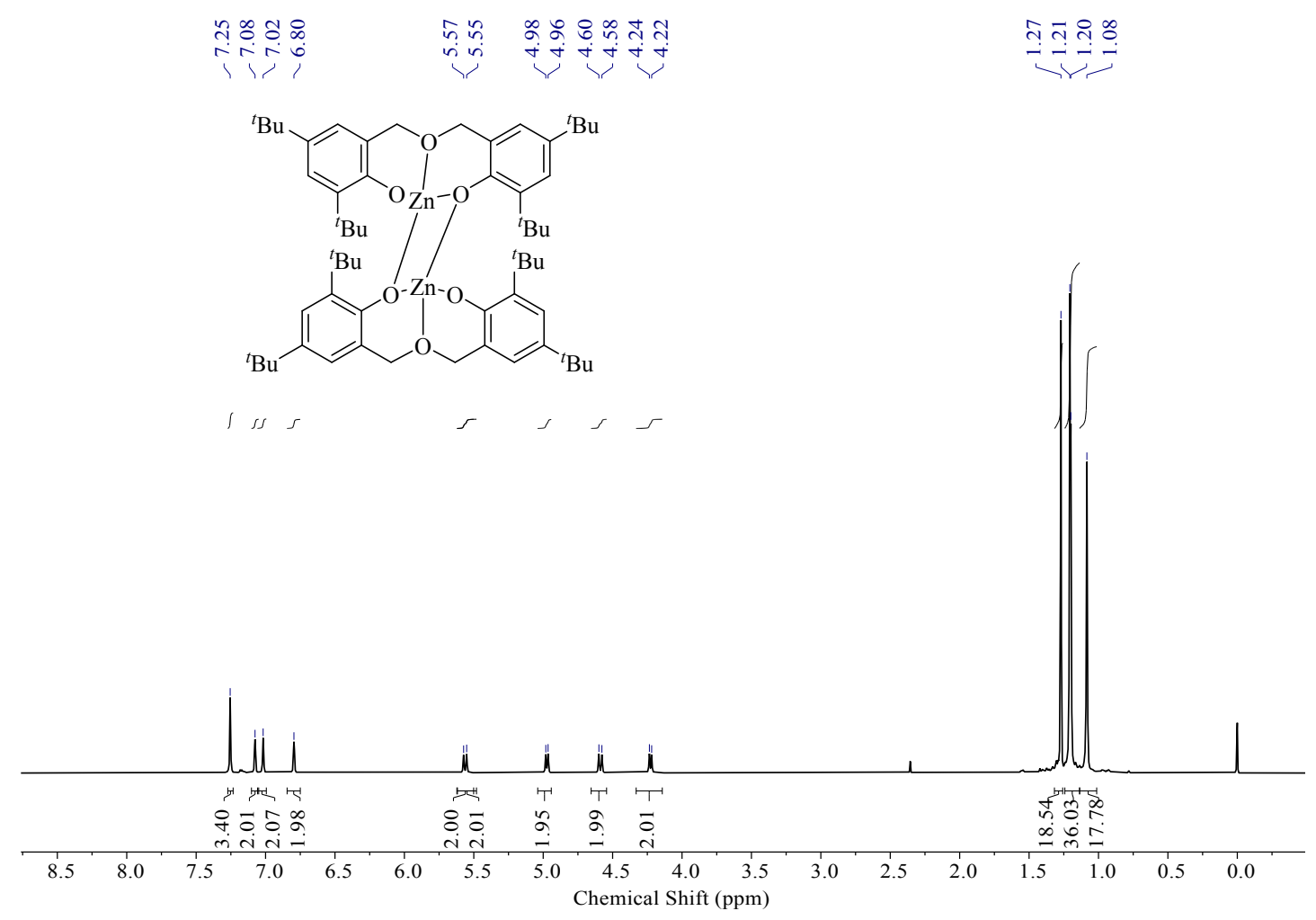

Figure S5. The ${ }^{1} \mathrm{H}$ NMR spectrum of complex $1\left(300 \mathrm{MHz}, \mathrm{CDCl}_{3}\right)$.
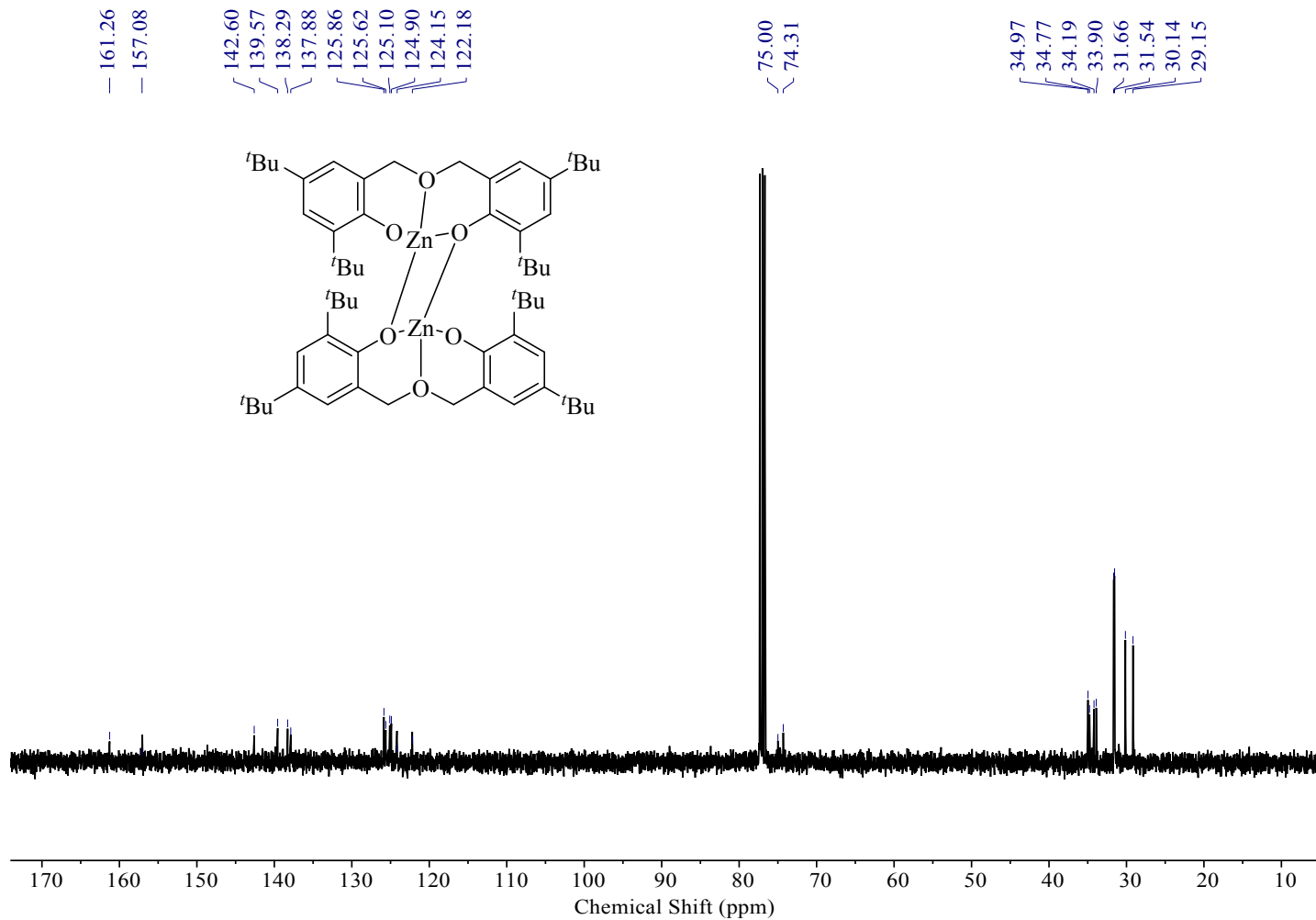

Figure S6. The ${ }^{13} \mathrm{C}$ NMR spectrum of complex $1\left(75 \mathrm{MHz}, \mathrm{CDCl}_{3}\right)$. 

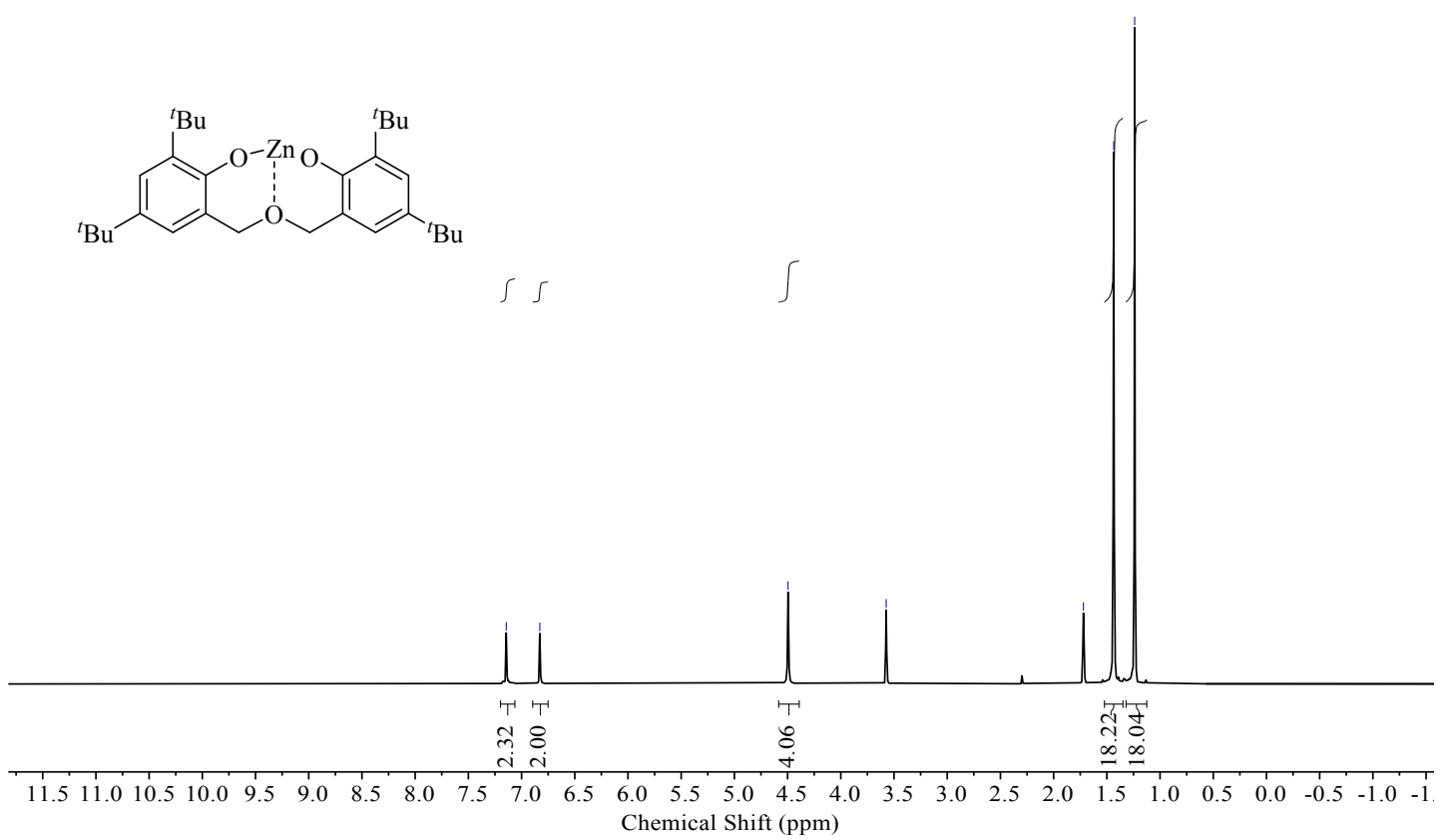

Figure S7. The ${ }^{1} \mathrm{H}$ NMR spectrum of complex 1 (600 MHz, THF- $\left.d_{8}\right)$

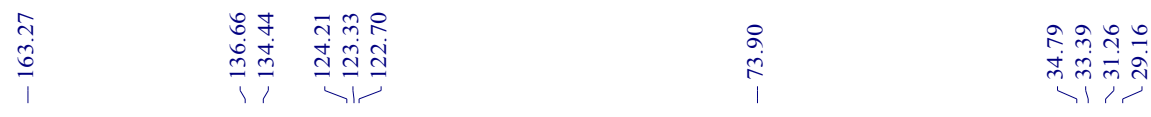<smiles></smiles>
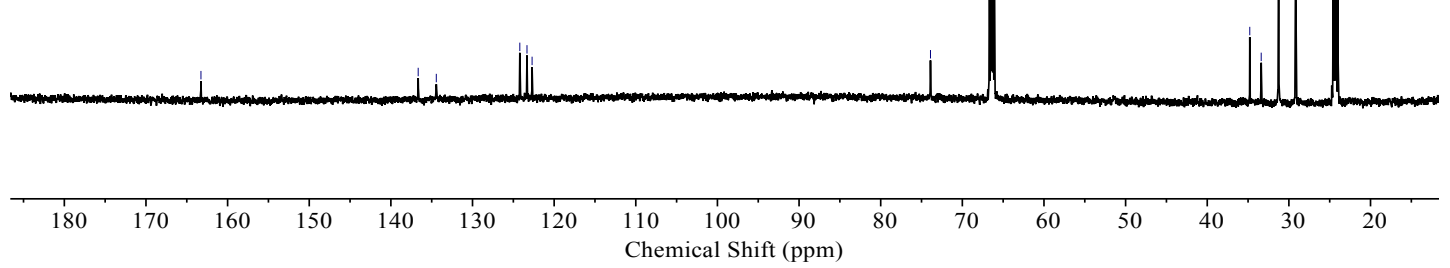

Figure S8. The ${ }^{13} \mathrm{C}$ NMR spectrum of complex $1\left(150 \mathrm{MHz}, \mathrm{THF}-d_{8}\right)$.

Complex 2, yield $0.6 \mathrm{~g}(78 \%) .{ }^{1} \mathrm{H}$ NMR $(400 \mathrm{MHz}$, Chloroform- $d) \delta 7.29-6.55(\mathrm{~m}, 48 \mathrm{H}), 4.56(\mathrm{~d}, J=9.4$ $\mathrm{Hz}, 2 \mathrm{H}), 3.75(\mathrm{~d}, J=13.2 \mathrm{~Hz}, 4 \mathrm{H}), 3.66(\mathrm{~d}, J=13.5 \mathrm{~Hz}, 2 \mathrm{H}), 1.78-1.58(\mathrm{~m}, 24 \mathrm{H}), 1.45(\mathrm{~s}, 6 \mathrm{H}), 1.28$ (s, $6 \mathrm{H}), 1.26(\mathrm{~s}, 6 \mathrm{H}), 0.87(\mathrm{~s}, 6 \mathrm{H}) .{ }^{13} \mathrm{C}$ NMR $(101 \mathrm{MHz}$, Chloroform-d) $\delta$ 161.09, 155.82, 152.00, 151.31, $150.81,150.16,142.15,138.58,137.38,136.77,128.50,128.04,127.73,127.63,127.30,126.79,126.76$, 
$126.67,125.63,125.51,125.26,125.21,124.93,124.53,124.29,122.49,73.84,73.04,42.53,42.28,42.15$, $42.10,33.60,31.03,29.34,29.13,27.72$.

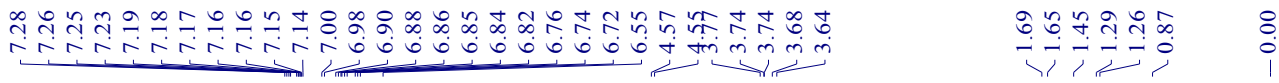

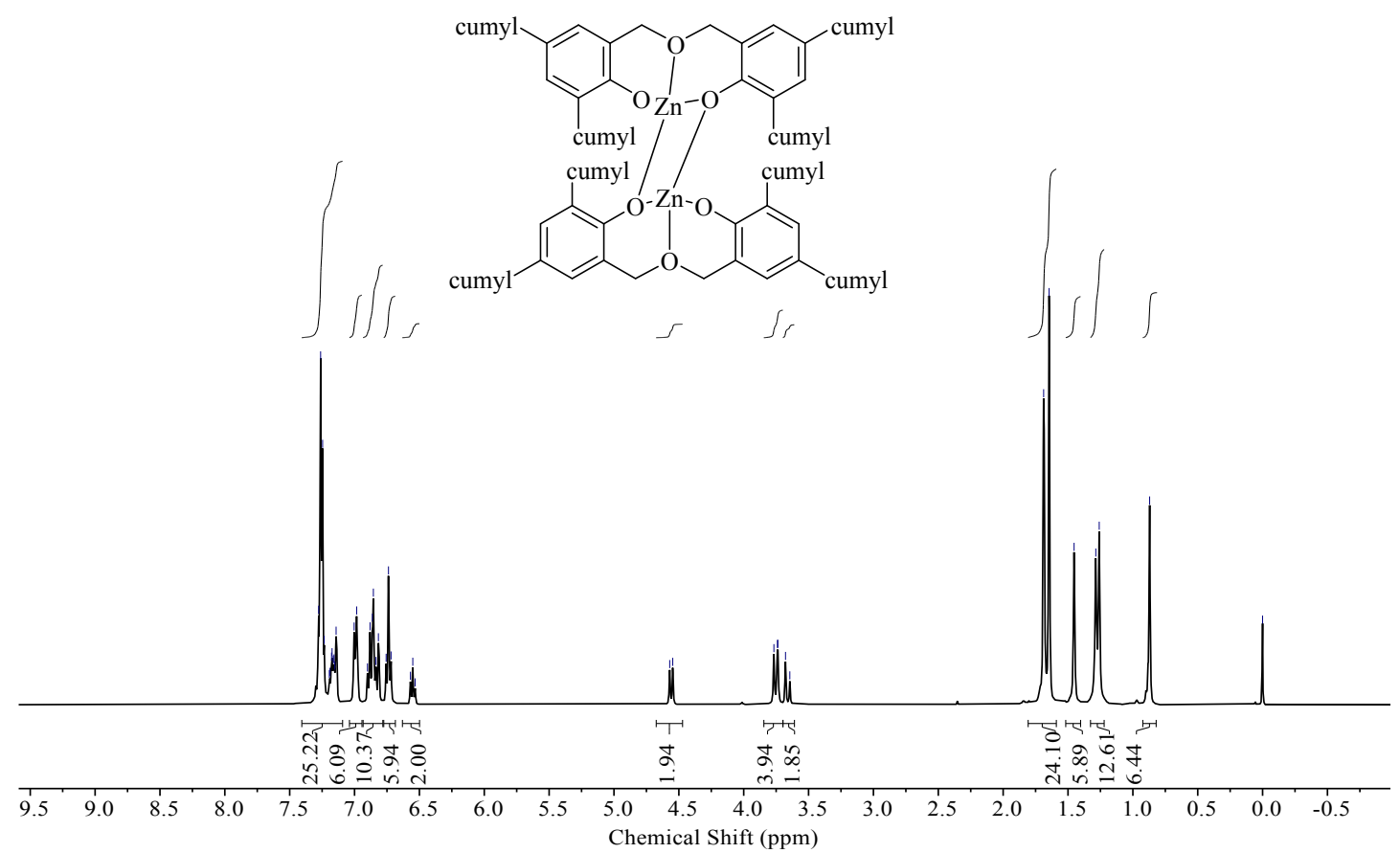

Figure S9. The ${ }^{1} \mathrm{H}$ NMR spectrum of complex $2\left(400 \mathrm{MHz}, \mathrm{CDCl}_{3}\right)$.
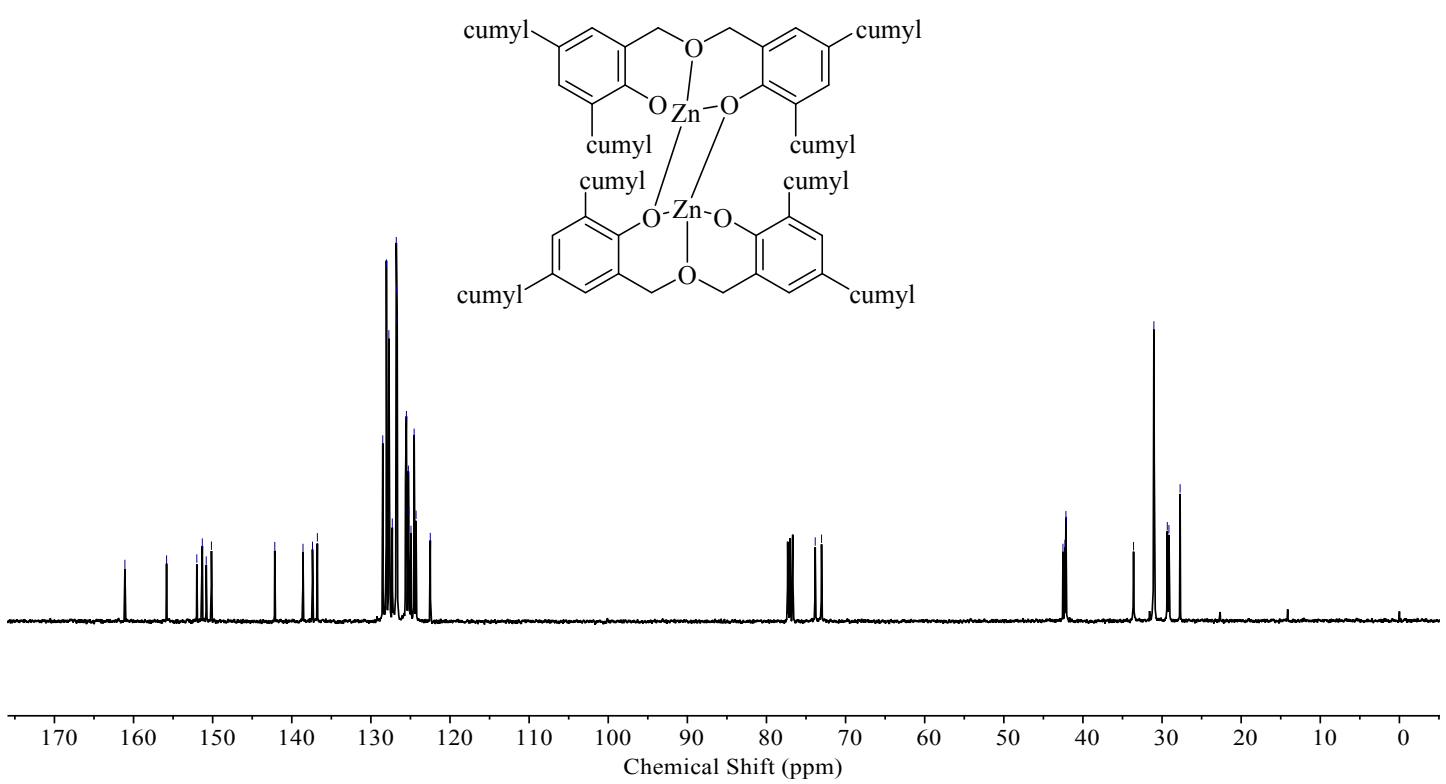

Figure $\mathrm{S} 10$. The ${ }^{13} \mathrm{C}$ NMR spectrum of complex $2\left(100 \mathrm{MHz}, \mathrm{CDCl}_{3}\right)$. 


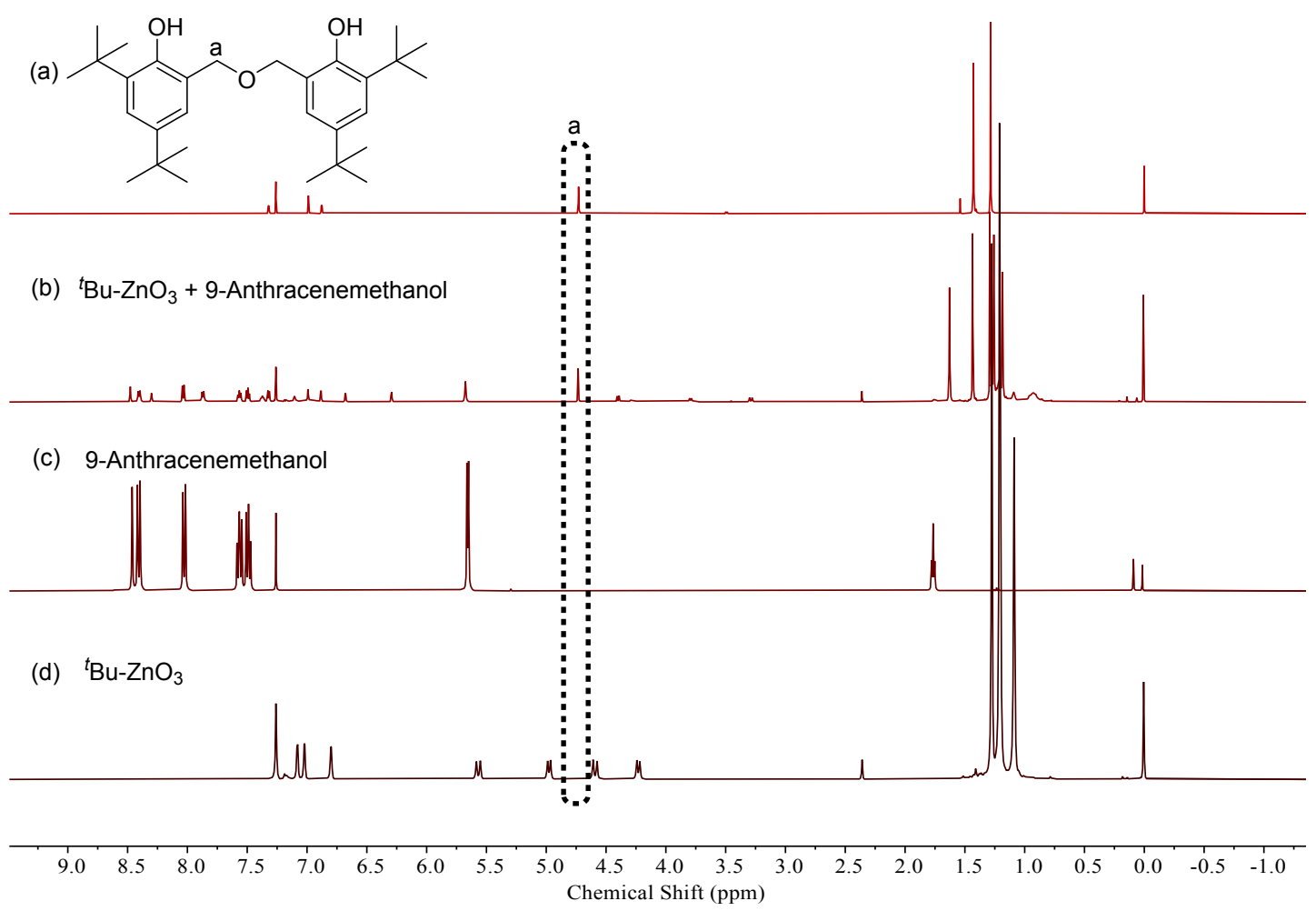

Figure S11. ${ }^{1} \mathrm{H}$ NMR spectra of (a) $\mathrm{L}^{1} \mathrm{H}_{2}$, (b) the mixture of 9-anthracenemethanol and complex 1 with the ratio of 1:1, (c) 9-anthracenemethanol. (d) complex 1 in $\mathrm{CDCl}_{3}$.

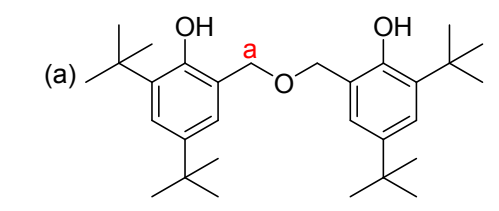

(c) 9-Anthracenemethanol

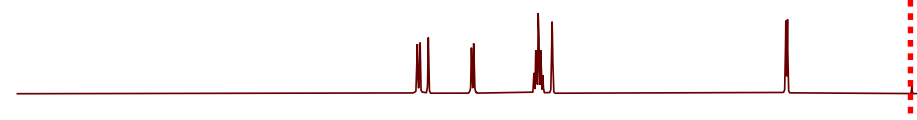

(b) ${ }^{t} \mathrm{Bu}-\mathrm{ZnO}_{3}+9$-Anthracenemethanol

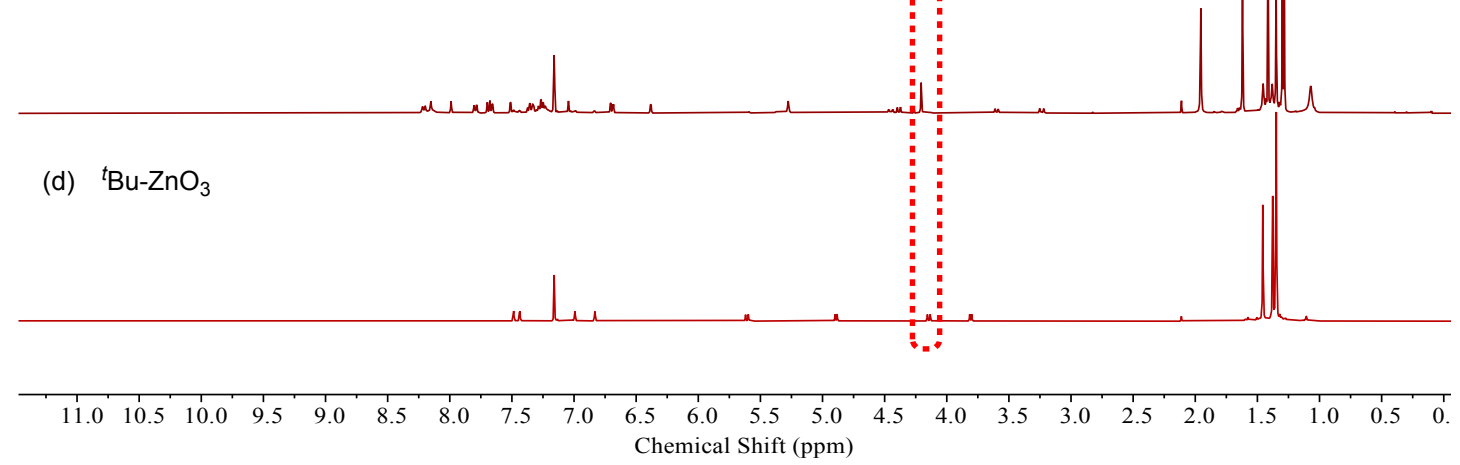

Figure S12. ${ }^{1} \mathrm{H}$ NMR spectra of (a) $\mathrm{L}^{1} \mathrm{H}_{2}$, (b) 9-anthracenemethanol. (c) the mixture of 9-anthracenemethanol and complex 1 with the ratio of 1:1, (d) complex 1 in $\mathrm{C}_{6} \mathrm{D}_{6}$. 

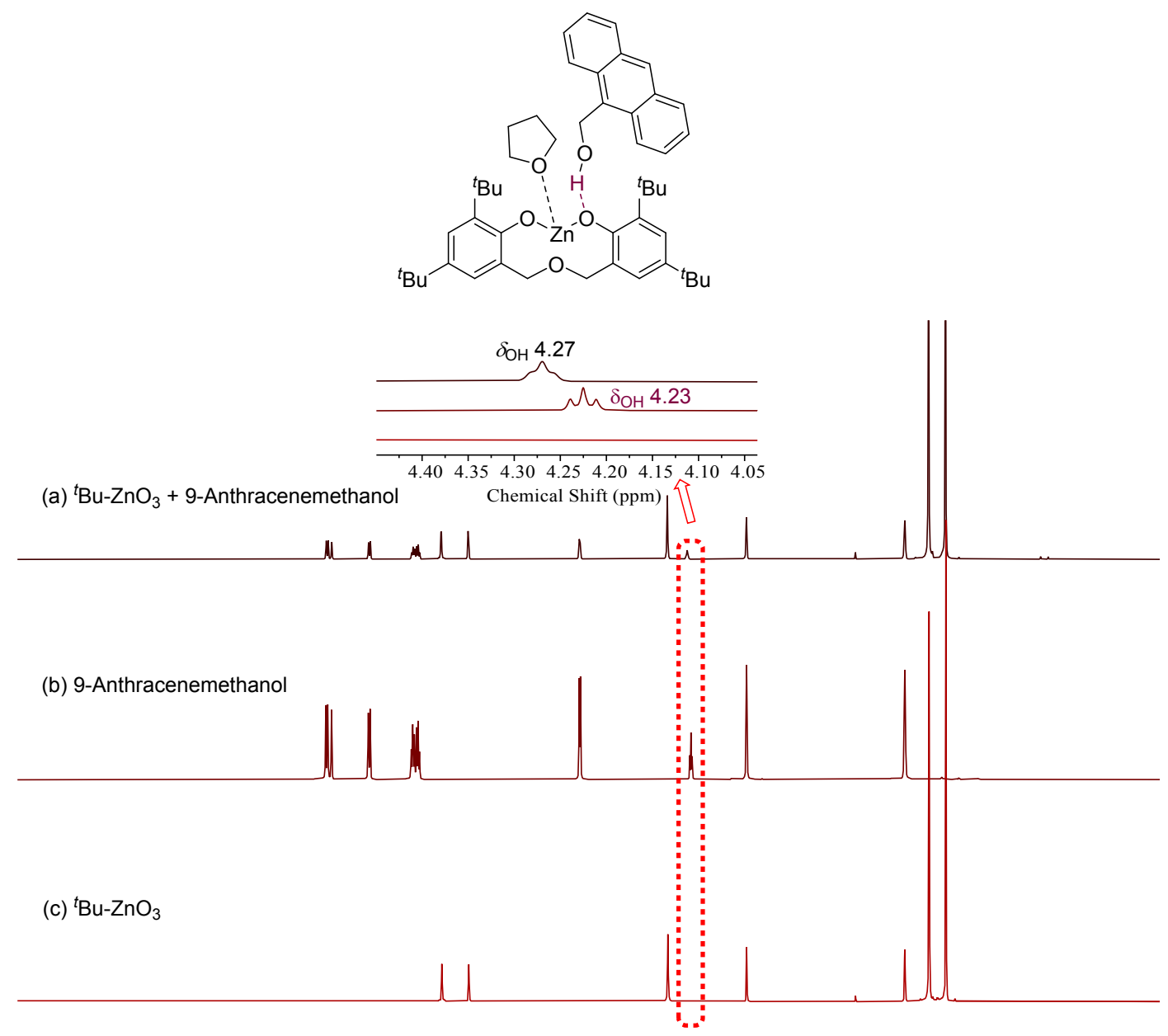

\begin{tabular}{|lllllllllllllllllllllllllllllll}
\hline 12.0 & 11.5 & 11.0 & 10.5 & 10.0 & 9.5 & 9.0 & 8.5 & 8.0 & 7.5 & 7.0 & 6.5 & 6.0 & 5.5 & 5.0 & 4.5 & 4.0 & 3.5 & 3.0 & 2.5 & 2.0 & 1.5 & 1.0 & 0.5 & 0.0 & -0.5 & -1.0
\end{tabular} Chemical Shift (ppm)

Figure S13. ${ }^{1} \mathrm{H}$ NMR spectra of (a) the mixture of 9-anthracenemethanol and complex 1 with the ratio of 1:1, (b) 9-anthracenemethanol, (c) complex 1 in THF- $d_{8}$.
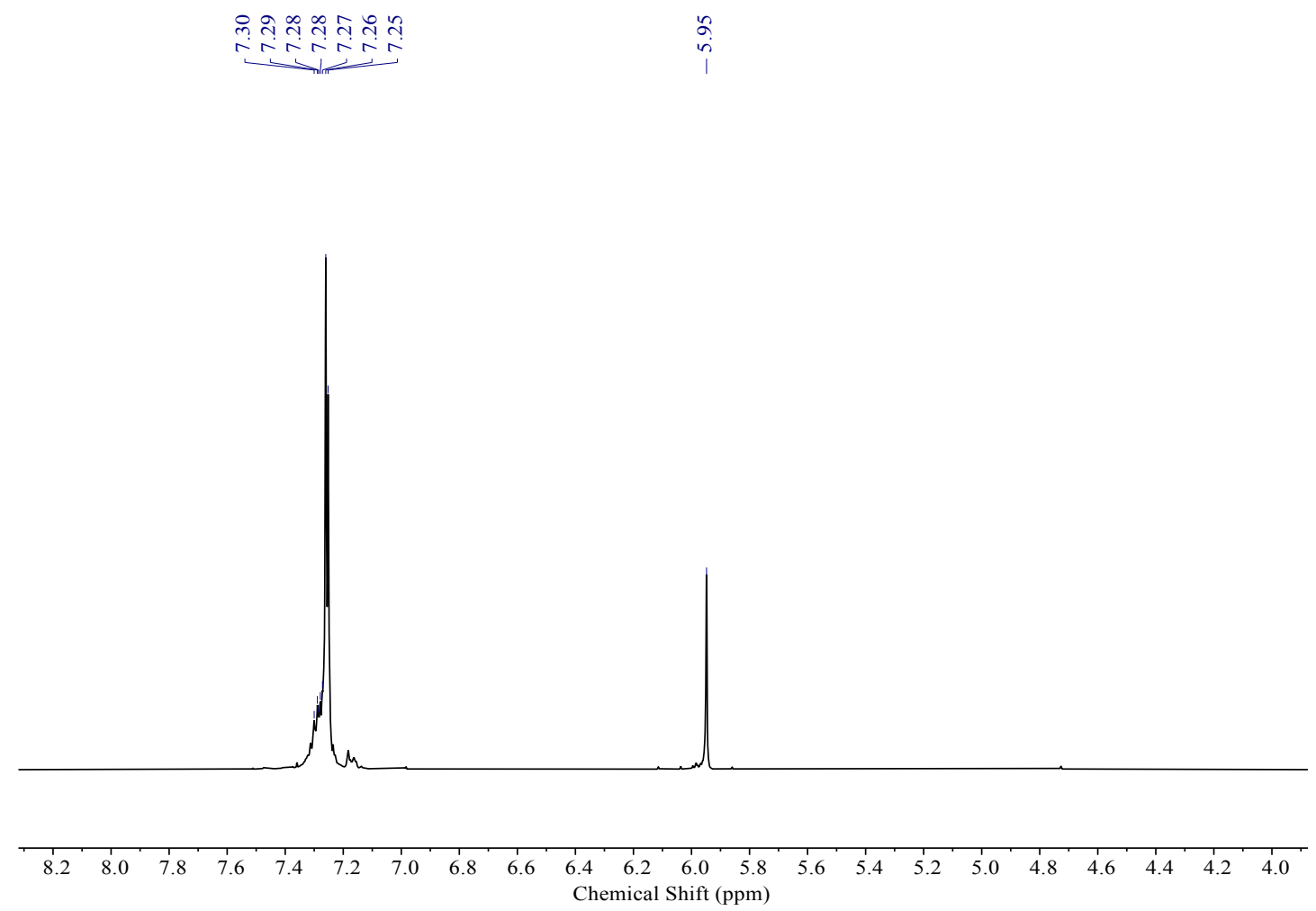

Figure S14. The ${ }^{1} \mathrm{H}$ NMR spectrum of PMA-100L in $\mathrm{CDCl}_{3}$ (Table 1, entry 1). 

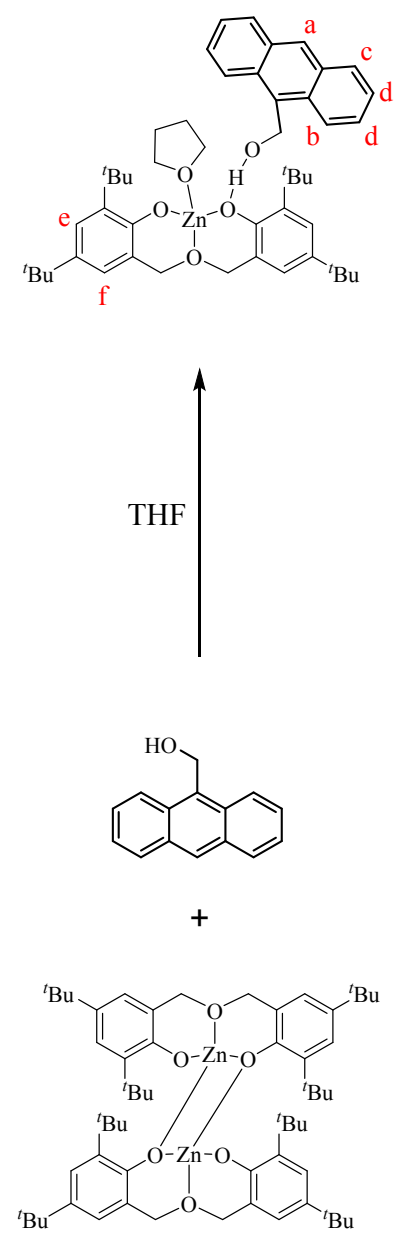

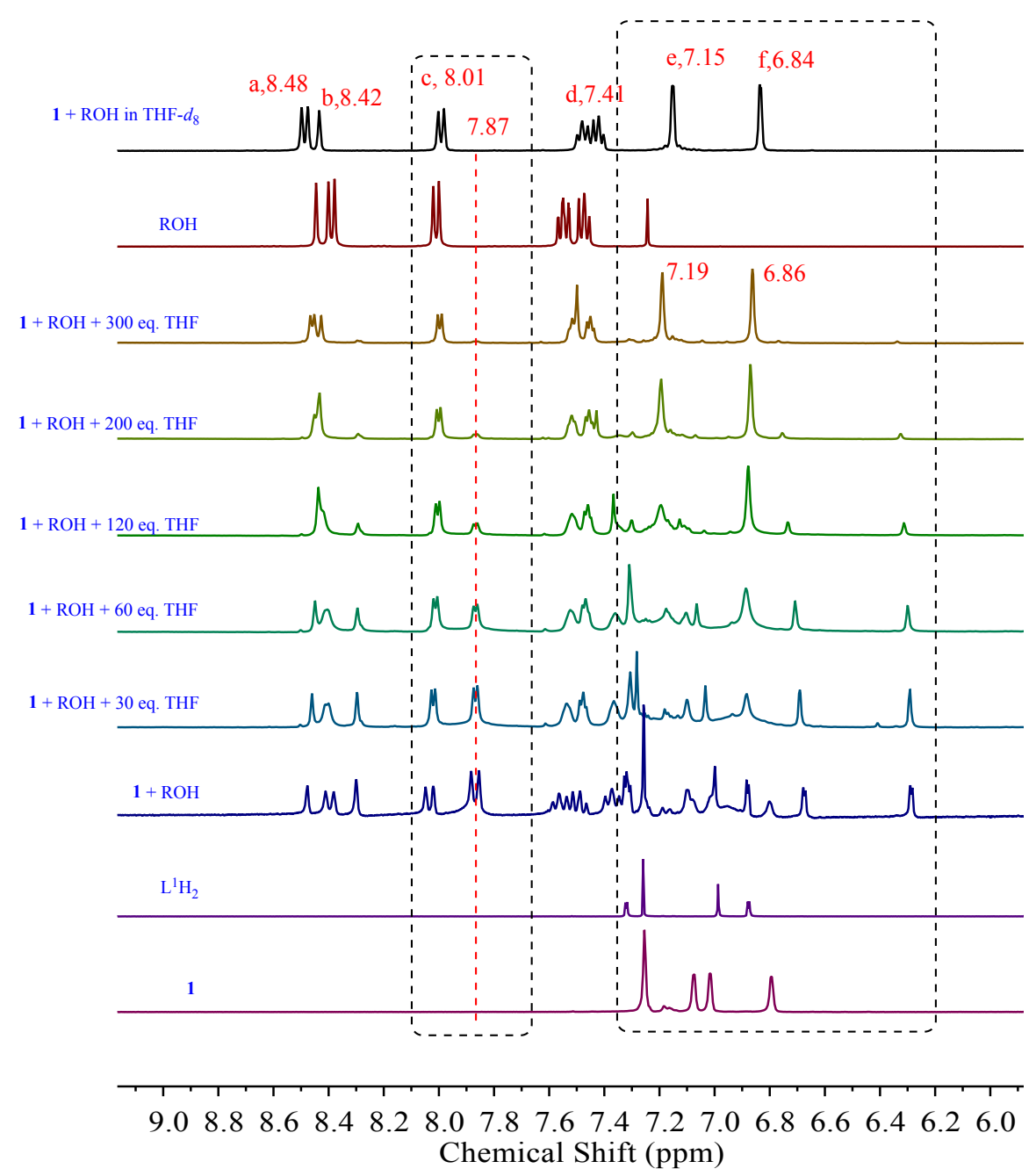

Figure S15. Reversible changes in situ of complex 1 and 1 eq. 9-anthracenemethanol in $\mathrm{CDCl}_{3}$ by adding different amounts of THF- $d_{8}$. 


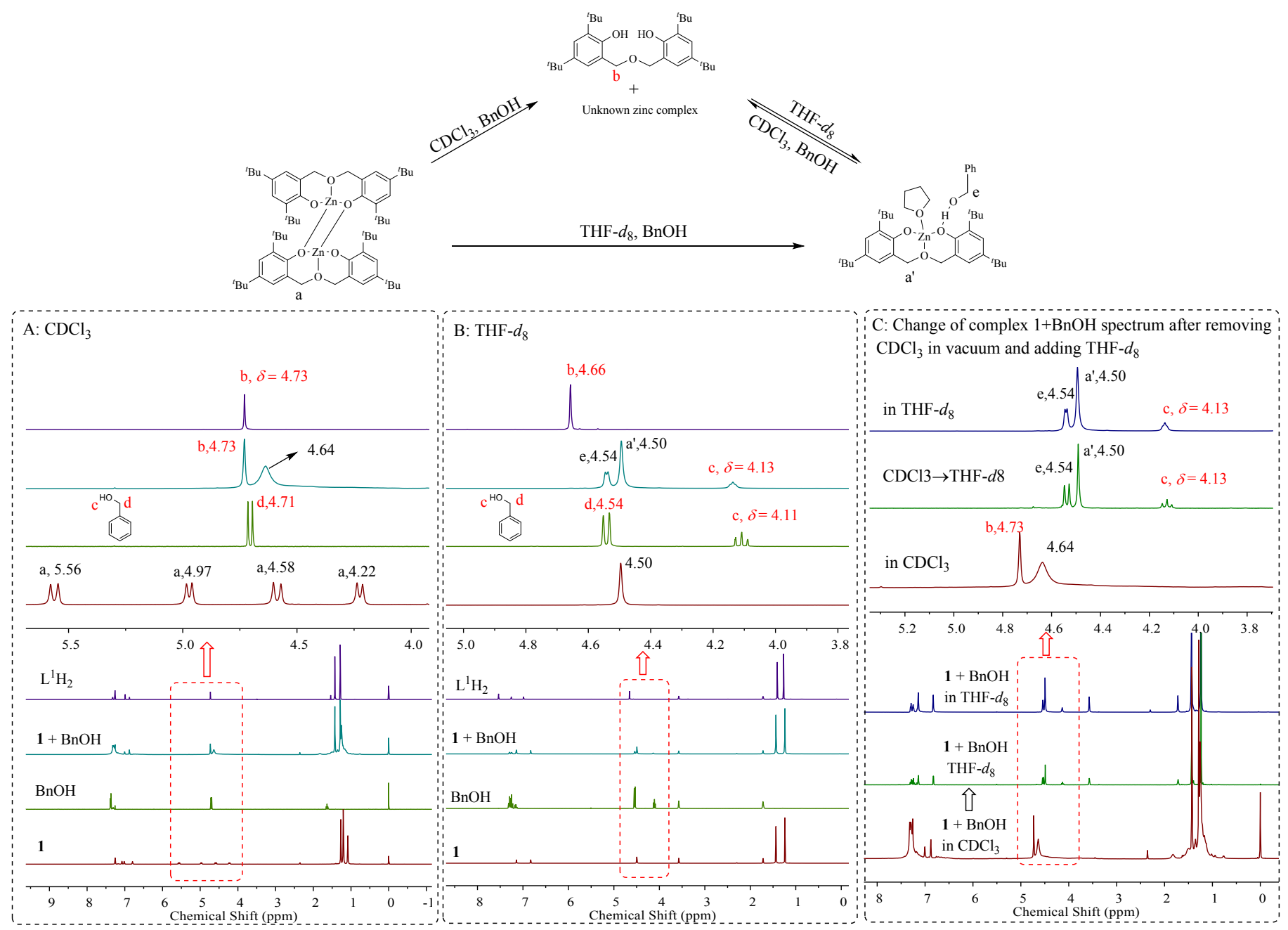

Figure S16. Reversible changes of complex 1 and benzyl alcohol in $\mathrm{CDCl}_{3}$ and THF. A: ${ }^{1} \mathrm{H}$ NMR spectra of $\mathrm{L}^{1} \mathrm{H}_{2}$, the mixture of $\mathrm{BnOH}$ and complex 1 with the 1:1 ratio of $\mathrm{BnOH}, \mathrm{BnOH}$ and complex 1 in $\mathrm{CDCl}_{3} ; \mathrm{B}$ ${ }^{1} \mathrm{H}$ NMR spectra of $\mathrm{L}^{1} \mathrm{H}_{2}$, the mixture of $\mathrm{BnOH}$ and complex 1 with the 1:1 ratio of $\mathrm{BnOH}, \mathrm{BnOH}$ and complex 1 in THF- $d_{8}$; C: The change of complex $1+\mathrm{BnOH}$ spectrum after removing $\mathrm{CDCl}_{3}$ in vacuum and adding THF- $d_{8}$. 
Table S1. Ring-opening polymerization of manOCA, PheOCA and LacOCA catalyzed by complex 1.

\begin{tabular}{|c|c|c|c|c|c|c|c|}
\hline Entry & {$[\mathrm{Zn}]_{0} /[\mathrm{BnOH}]_{0} /[\text { Monomer }]_{0}$} & $\mathrm{~T}\left({ }^{\circ} \mathrm{C}\right)$ & $\begin{array}{l}\text { Time } \\
\text { (min) }\end{array}$ & $\begin{array}{c}\text { Conv. }^{b} \\
(\%)\end{array}$ & $\begin{array}{l}M_{\mathrm{n}, \mathrm{GPC}^{c}} \\
(\mathrm{~g} / \mathrm{mol})\end{array}$ & $\begin{array}{c}M_{\mathrm{n}, \text { calcd }^{d}} \\
(\mathrm{~g} / \mathrm{mol})\end{array}$ & $\oslash$ \\
\hline $1^{\mathrm{e}}$ & $1: 1: 100(L-m a n O C A)$ & RT & 15 & 99 & 11900 & 13500 & 1.18 \\
\hline 2 & $1: 1: 400(L-m a n O C A)$ & RT & $3 \mathrm{~h}$ & 63 & 27400 & 33800 & 1.20 \\
\hline 3 & 1:1:100(rac-manOCA) & RT & 10 & 52 & 5800 & 7000 & 1.17 \\
\hline 4 & 1:1:100(rac-manOCA) & -15 & $3 \mathrm{~h}$ & 31 & 3800 & 4300 & 1.11 \\
\hline 5 & 1:1:100(L-LacOCA $)$ & RT & 10 & 99 & 8100 & 7200 & 1.13 \\
\hline 6 & 1:1:100(rac-LacOCA) & RT & 10 & 95 & 6000 & 6900 & 1.09 \\
\hline 7 & 1:1:100(L-PheOCA) & RT & 10 & 99 & 15900 & 14700 & 1.77 \\
\hline 8 & 1:1:100(rac-PheOCA) & RT & 10 & 82 & 11000 & 12100 & 1.99 \\
\hline 9 & $1: 0.5: 250(L-\mathrm{manOCA})$ & RT & $1.5 \mathrm{~h}$ & 91 & 32300 & 61000 & 1.50 \\
\hline
\end{tabular}

${ }^{a}$ Conditions: reactions were carried out under a dry nitrogen atmosphere at room temperature in $2 \mathrm{~mL}$ THF, $0.01 \mathrm{mmol}$ of complex 1. ${ }^{b}$ Obtained via ${ }^{1} \mathrm{H}$ NMR analysis. ${ }^{c}$ Experimental $M_{\mathrm{n}}$ and $Ð$ determined by GPC in THF against polystyrene standards are not corrected. ${ }^{d}$ Calculated from the equation of (molar mass of monomer - molar mass of $\left.\mathrm{CO}_{2}\right) \times[\text { mononmer }]_{0} /[\mathrm{BnOH}]_{0} \times$ Conversion $\%+$ the molar mass of $\mathrm{BnOH} .{ }^{e}$ using the pre-prepared mixture of complex $\mathbf{1}$ and $\mathrm{BnOH}$ as a catalyst (the pre-prepared mixture of complex $\mathbf{1}+\mathrm{BnOH}$ was obtained via remove the THF solvent in the solution of complex 1 and $\mathrm{BnOH}$ under vacuum (see above Figure S16) ). 


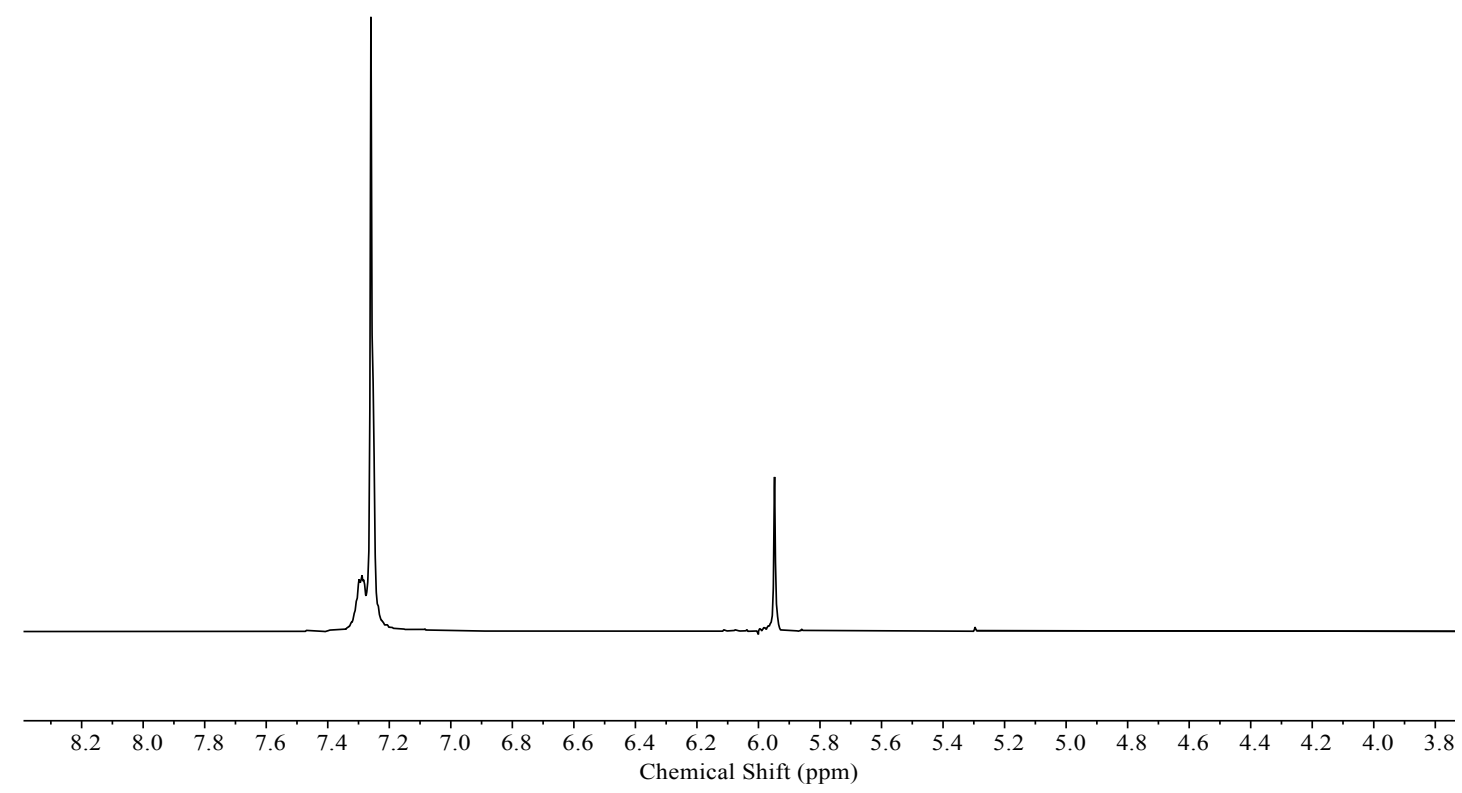

Figure S17. The ${ }^{1} \mathrm{H}$ NMR spectrum of PMA in $\mathrm{CDCl}_{3}$ (Table 1, entry 2).

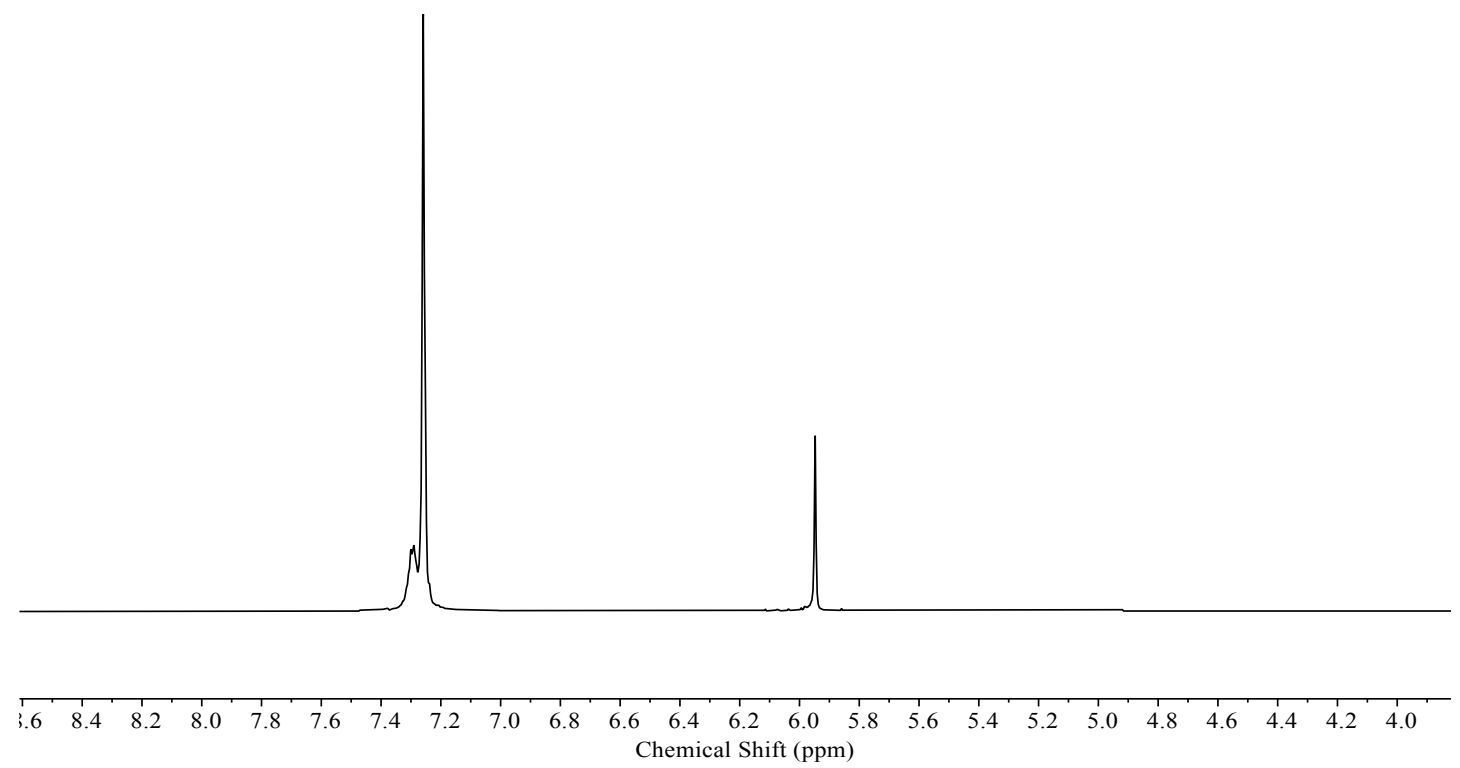

Figure S18. The ${ }^{1} \mathrm{H}$ NMR spectrum of PMA in $\mathrm{CDCl}_{3}$ (Table 1, entry 3). 


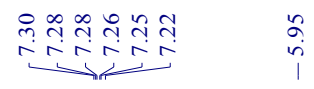
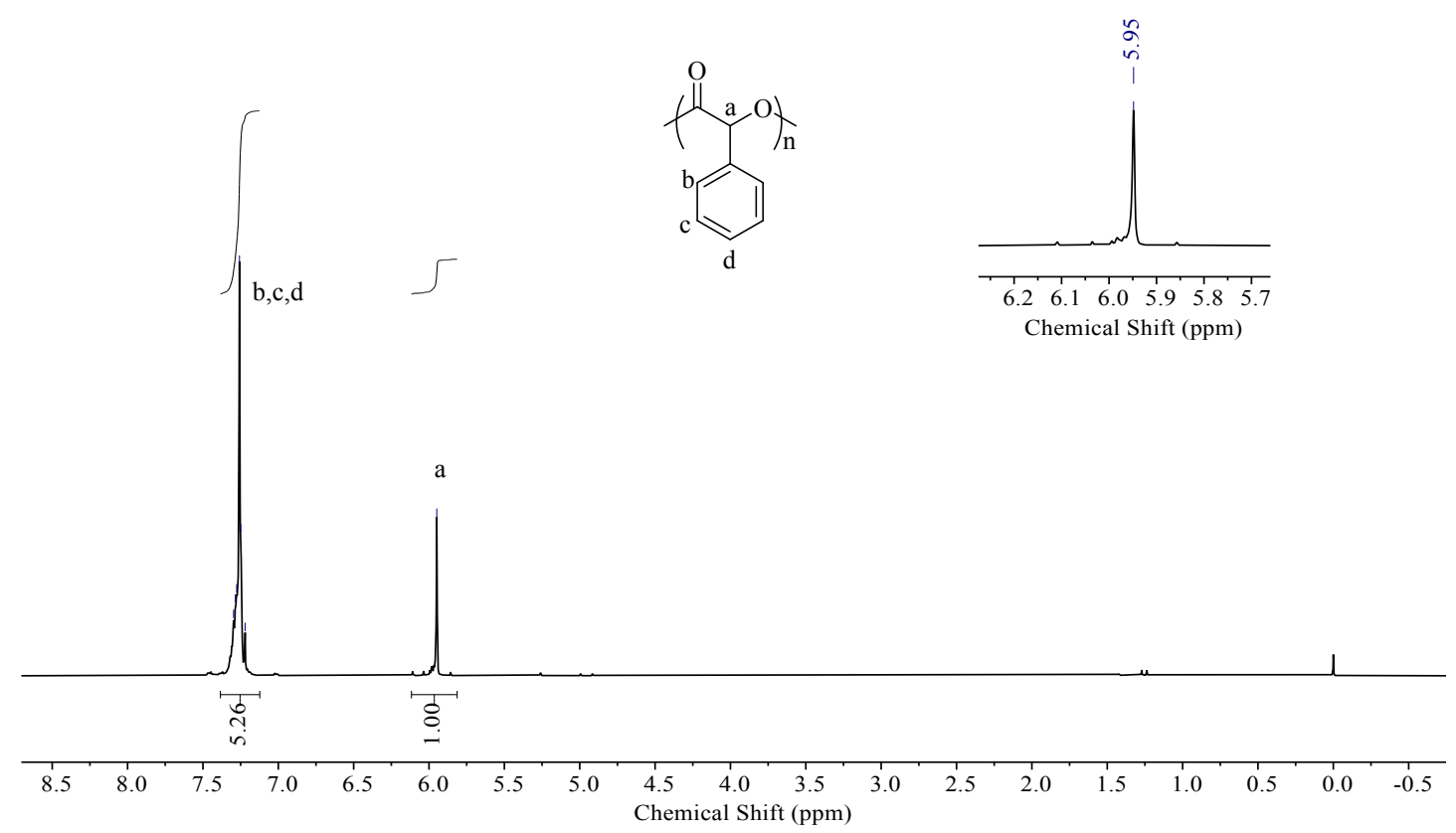

Figure S19. The ${ }^{1} \mathrm{H}$ NMR spectrum of PMA-50L in $\mathrm{CDCl}_{3}$ (Table 1, entry 6).

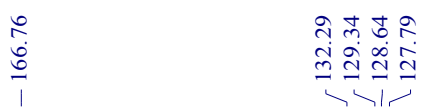

$\frac{i}{\sqrt[4]{n}}$
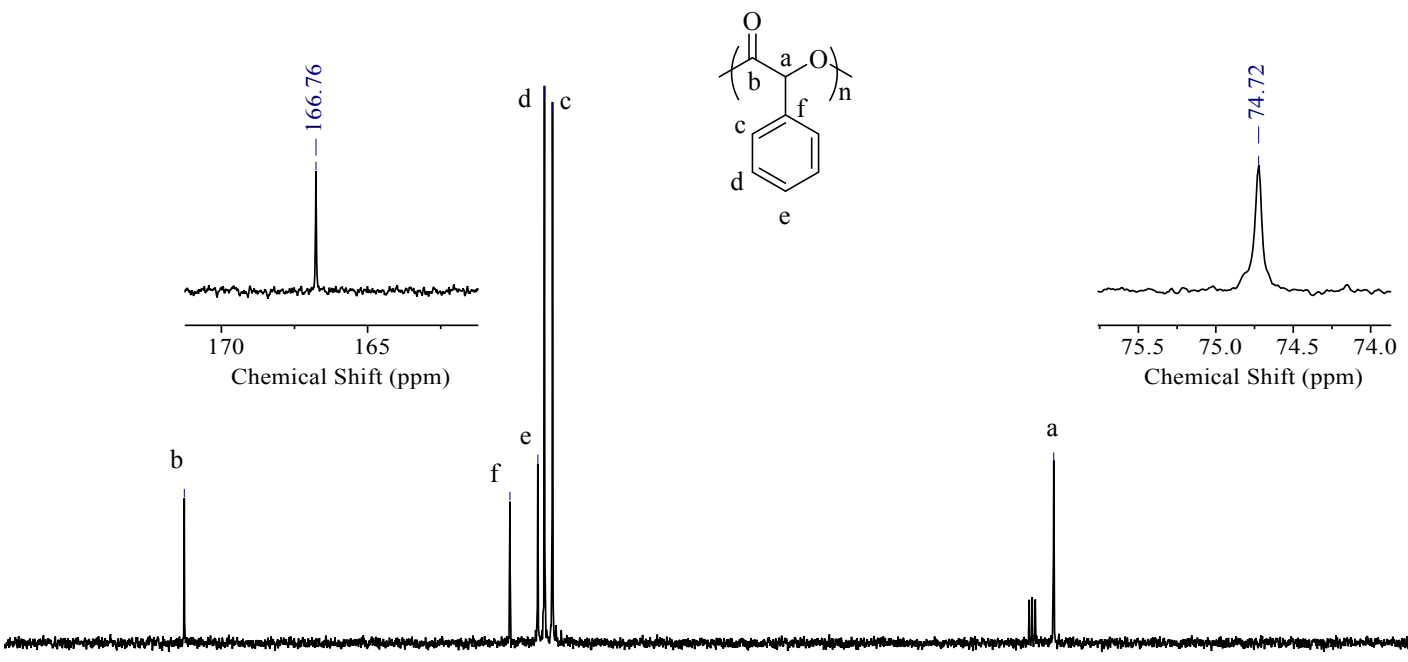

\begin{tabular}{lllllllllllllllllllllllllllllllllllllll}
\hline 85 & 180 & 175 & 170 & 165 & 160 & 155 & 150 & 145 & 140 & 135 & 130 & 125 & 120 & 115 & 110 & 105 & 100 & 95 & 90 & 85 & 80 & 75 & 70 & 65 & 60 & 55 & 50 & 45 & 40 & 3
\end{tabular} Chemical Shift (ppm)

Figure S20. The ${ }^{13} \mathrm{C}$ NMR spectrum of PMA-50L in $\mathrm{CDCl}_{3}$ (Table 1, entry 6). 


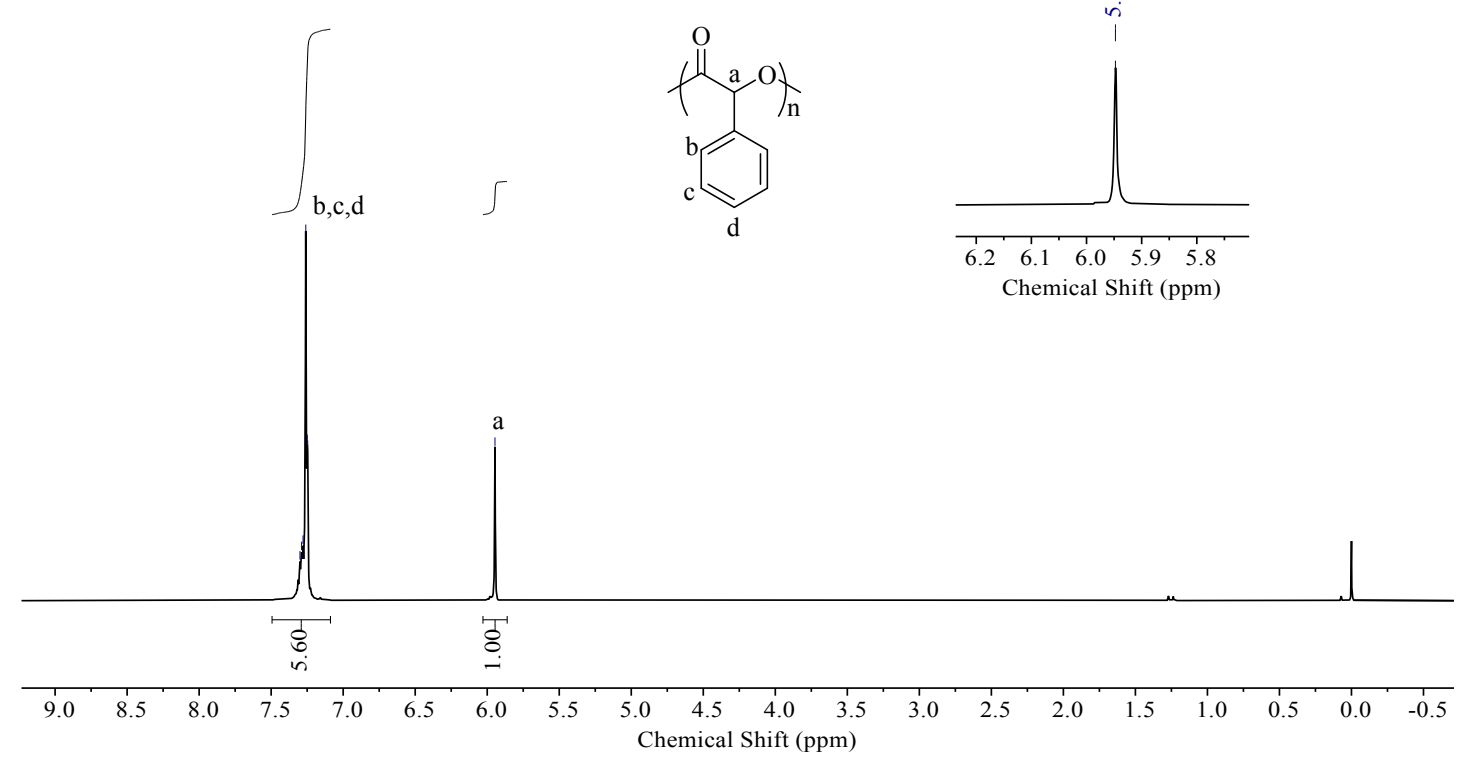

Figure S21. The ${ }^{1} \mathrm{H}$ NMR spectrum of the stereoblock copolymer of PMA-100D-b-100L in $\mathrm{CDCl}_{3}\left(\mathrm{Table}^{2}\right.$, entry 3).
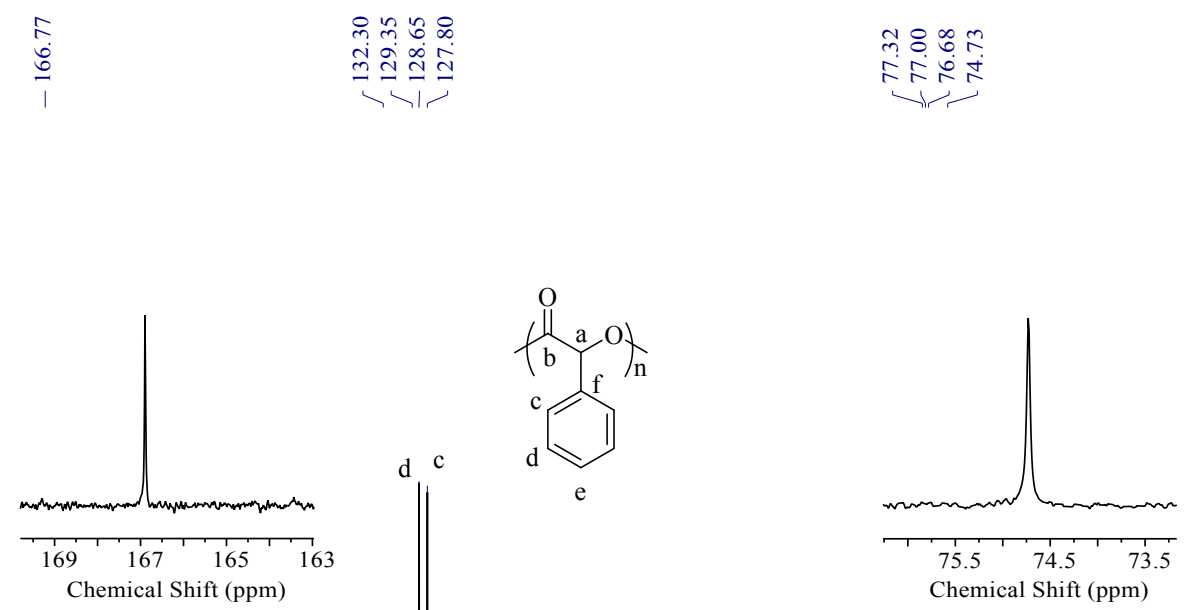

\begin{tabular}{lllllllllllllllllllllllllllllllllllllll}
\hline 85 & 180 & 175 & 170 & 165 & 160 & 155 & 150 & 145 & 140 & 135 & 130 & 125 & 120 & 115 & 110 & 105 & 100 & 95 & 90 & 85 & 80 & 75 & 70 & 65 & 60 & 55 & 50 & 45 & 41
\end{tabular}

Chemical Shift (ppm)

Figure S22. The ${ }^{13} \mathrm{C}$ NMR spectrum of stereoblock copolymer of PMA-100D-b-100L in $\mathrm{CDCl}_{3}$ (Table2, entry 3). 

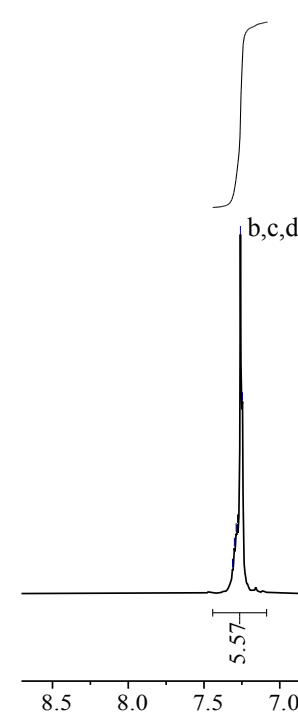

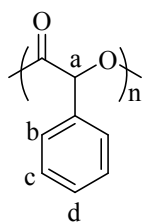

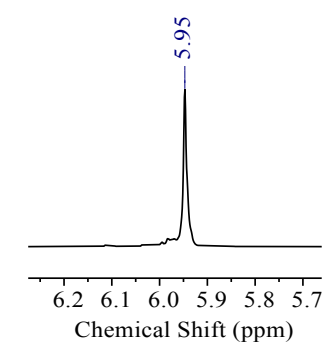

Figure S23. The ${ }^{1} \mathrm{H}$ NMR spectrum of the stereoblock copolymer of PMA-50D-b-50L in $\mathrm{CDCl}_{3}$ (Table2, entry 1).
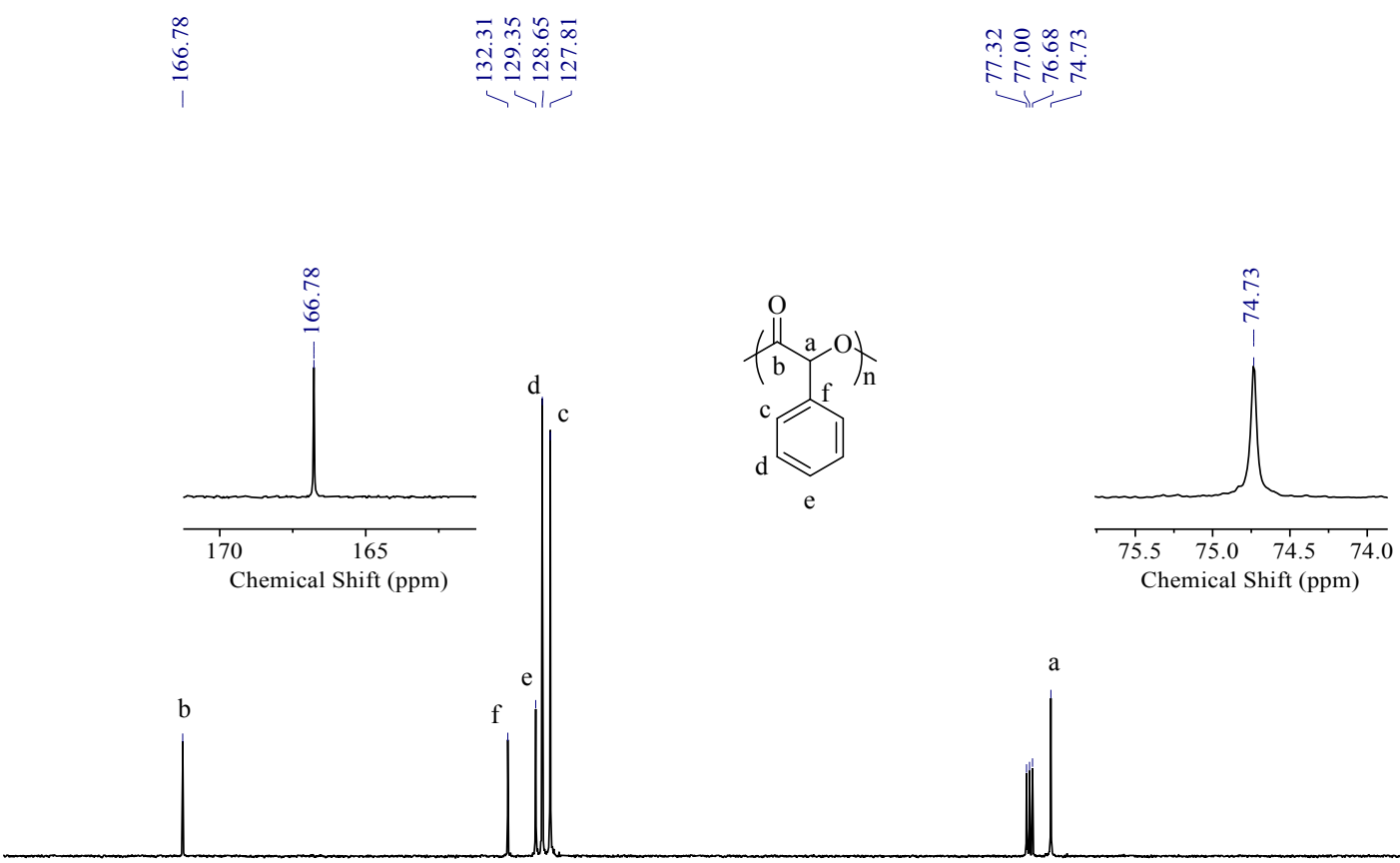

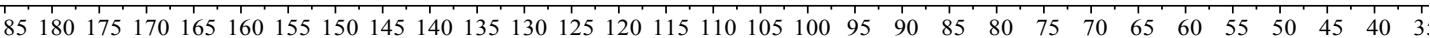

Chemical Shift (ppm)

Figure S24. The ${ }^{13} \mathrm{C}$ NMR spectrum of the stereoblock copolymer of PMA-50D-b-50L in $\mathrm{CDCl}_{3}\left(\mathrm{Table}^{2}\right.$, entry 1). 


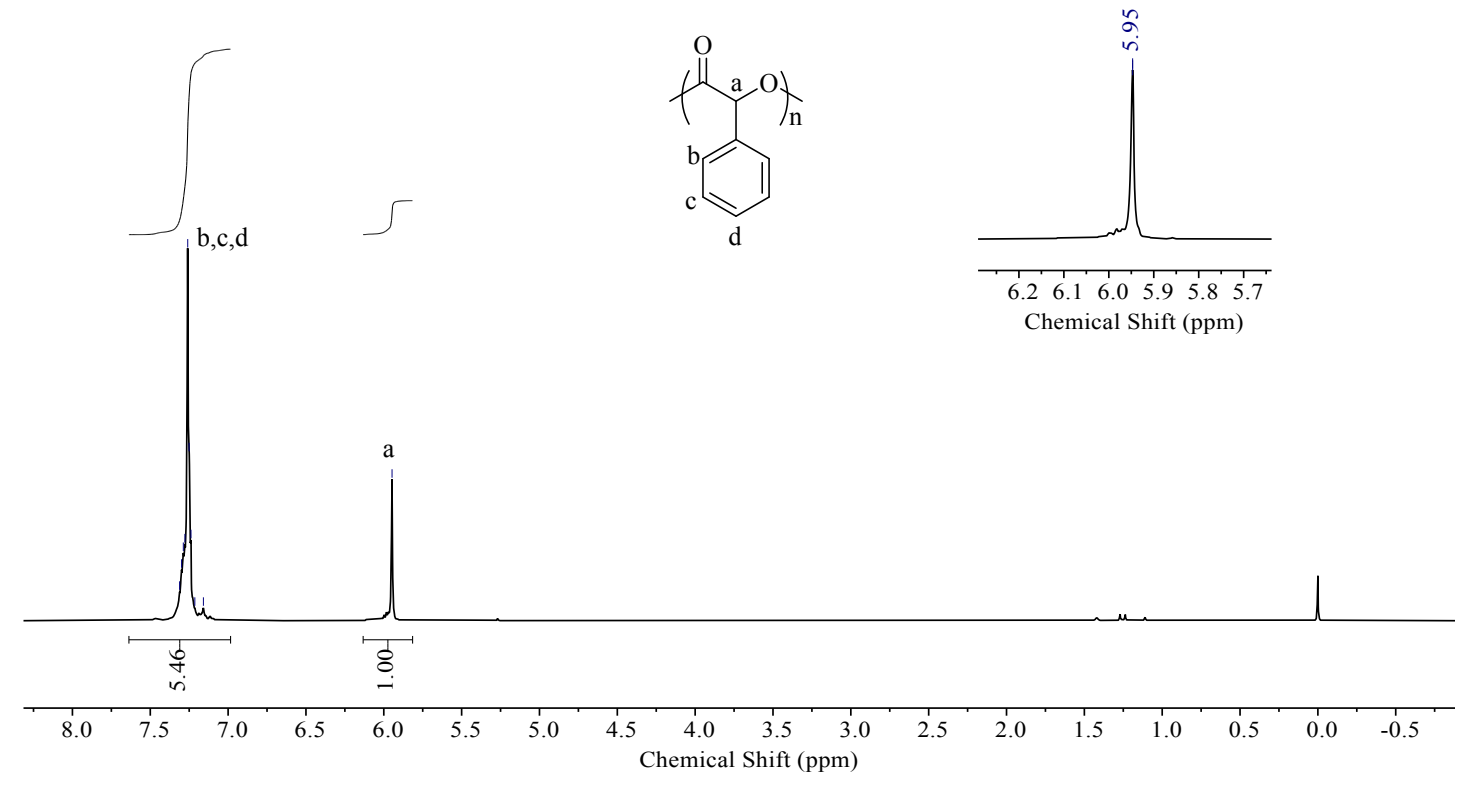

Figure S25. The ${ }^{1} \mathrm{H}$ NMR spectrum of the stereoblock copolymer of PMA-50D-b-50L-b-50D in $\mathrm{CDCl}_{3}$ (Table2, entry 4).

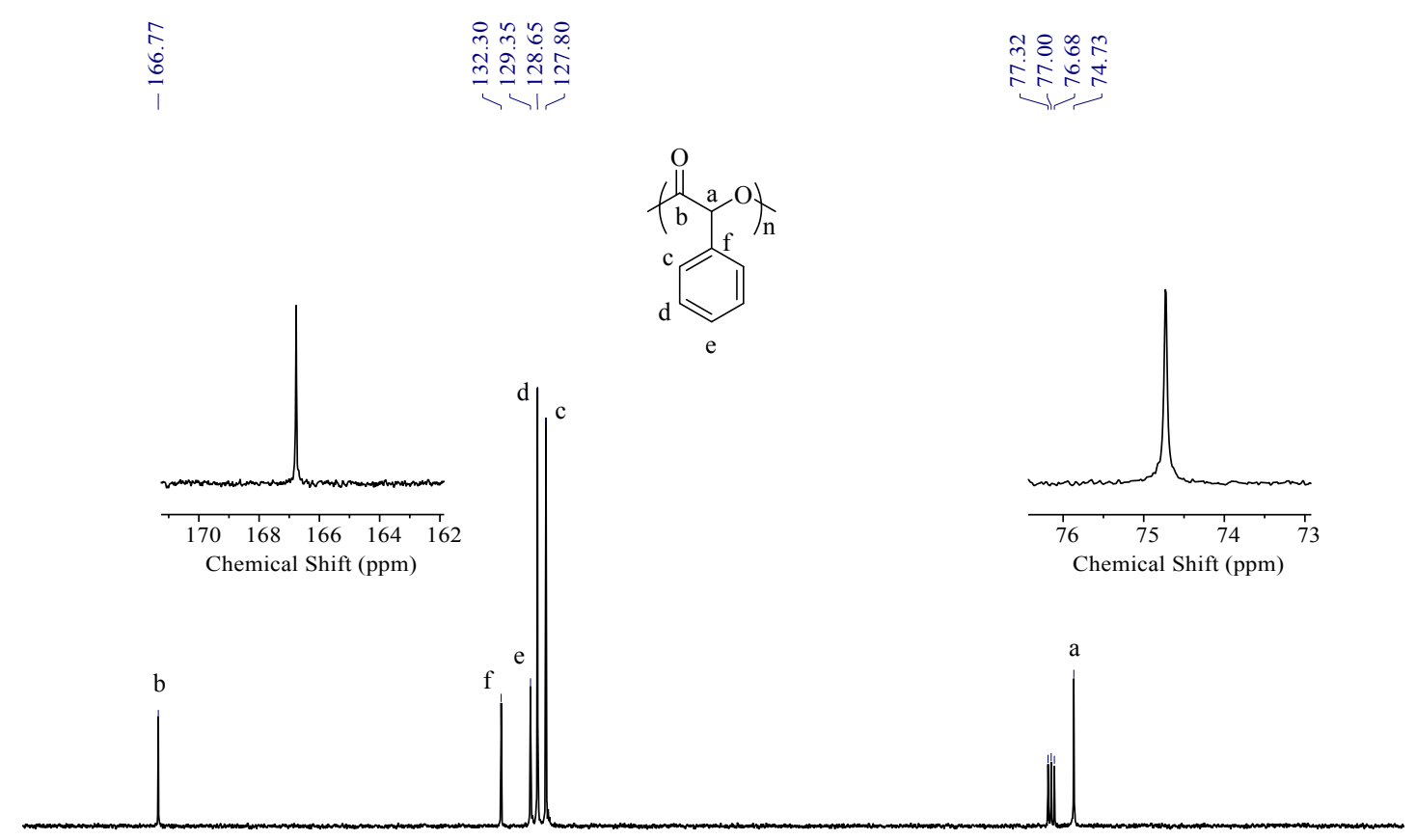

\begin{tabular}{llllllllllllllllllllllllllllllllllllllll}
\hline 80 & 175 & 170 & 165 & 160 & 155 & 150 & 145 & 140 & 135 & 130 & 125 & 120 & 115 & 110 & 105 & 100 & 95 & 90 & 85 & 80 & 75 & 70 & 65 & 60 & 55 & 50 & 45
\end{tabular} Chemical Shift (ppm)

Figure S26. The ${ }^{13} \mathrm{C}$ NMR spectrum of the stereoblock copolymer of PMA-50D-b-50L-b-50D in $\mathrm{CDCl}_{3}$ (Table2, entry 4). 


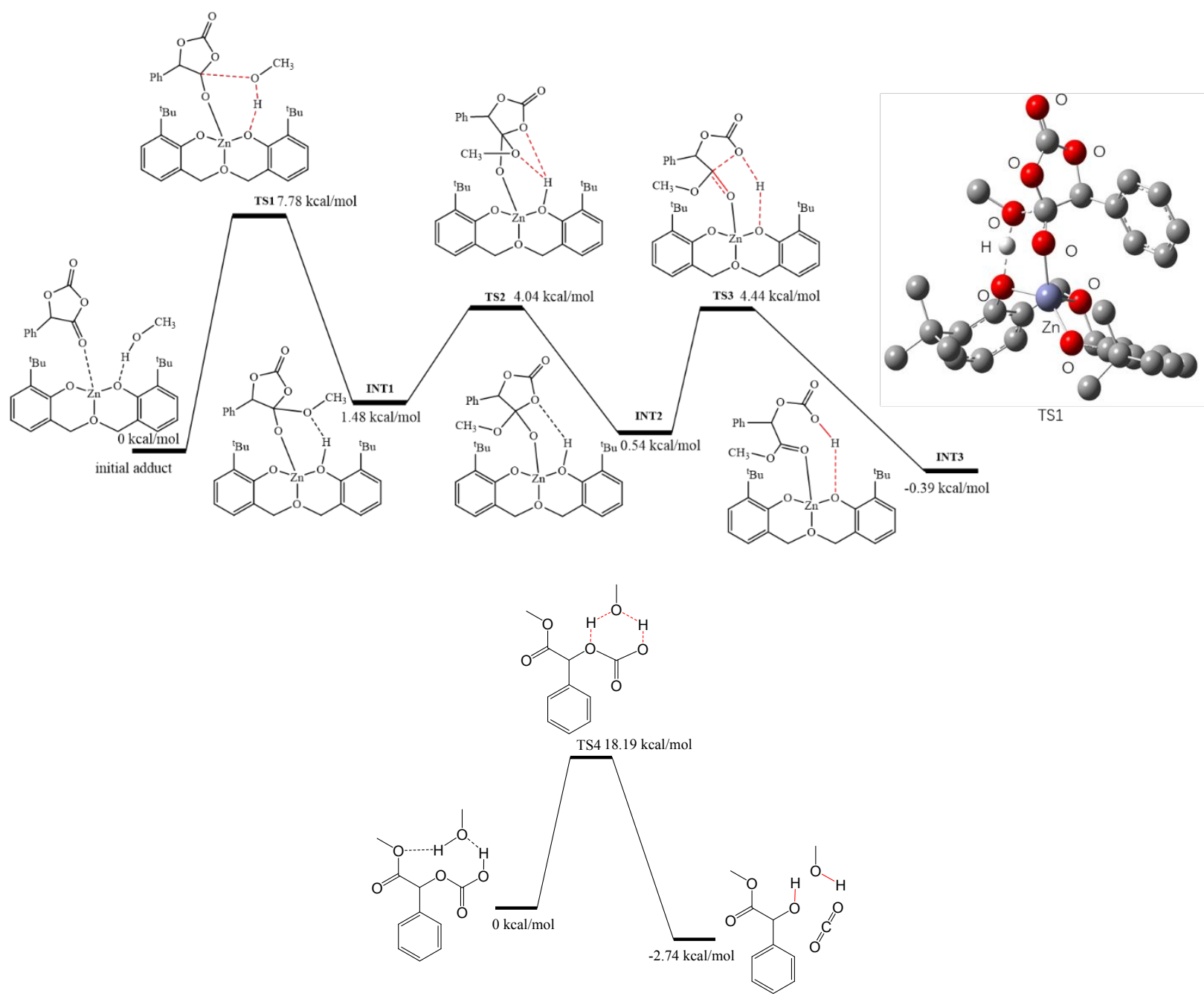

Figure S27. Free energy profiles calculated for the ring-opening polymerization of manOCA catalyzed by zinc complex through a ligand-assisted activated monomer mechanism, and the decarboxylation process of a carbonate intermediate.

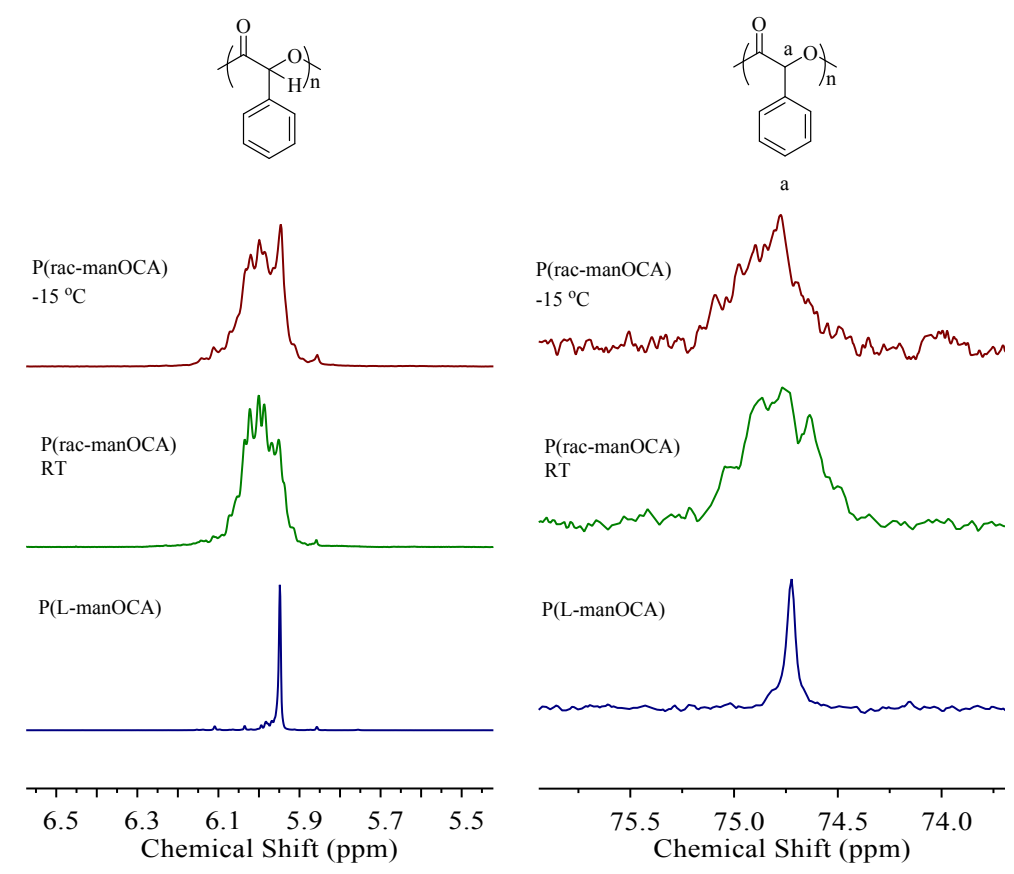

Figure S28. ROP of $L$-manOCA and rac-manOCA catalyzed by complex 1 at $-15{ }^{\circ} \mathrm{C}$ and RT. A: Methine resonances in the ${ }^{1} \mathrm{H}$ NMR spectra. B: Methine resonances in the ${ }^{13} \mathrm{C}$ NMR spectra (Table S1, entries 3-4). 


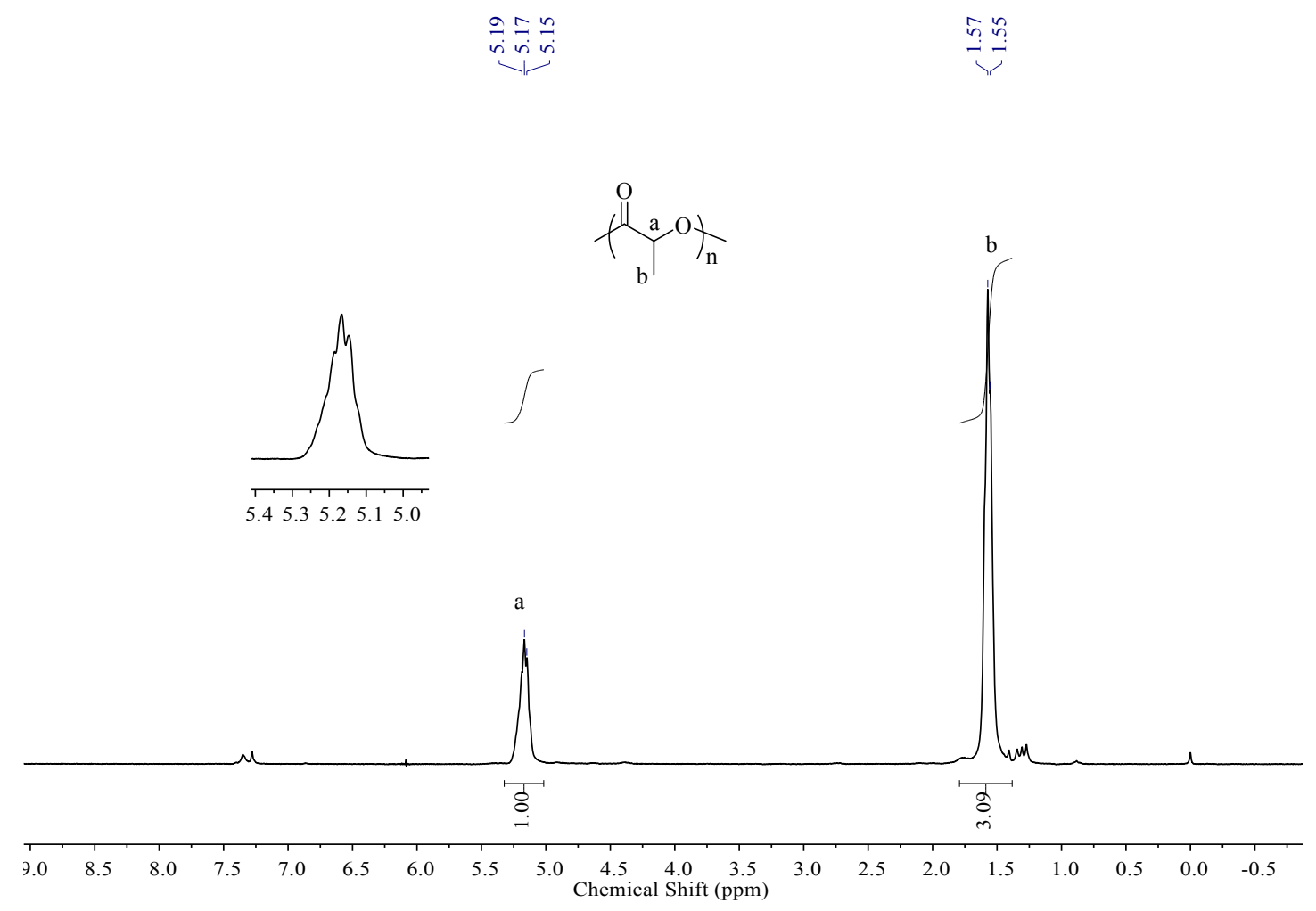

Figure S29. The ${ }^{1} \mathrm{H}$ NMR spectrum of the poly $\left(r a c\right.$-LacOCA) in $\mathrm{CDCl}_{3}$ (Table S1, entry 6).

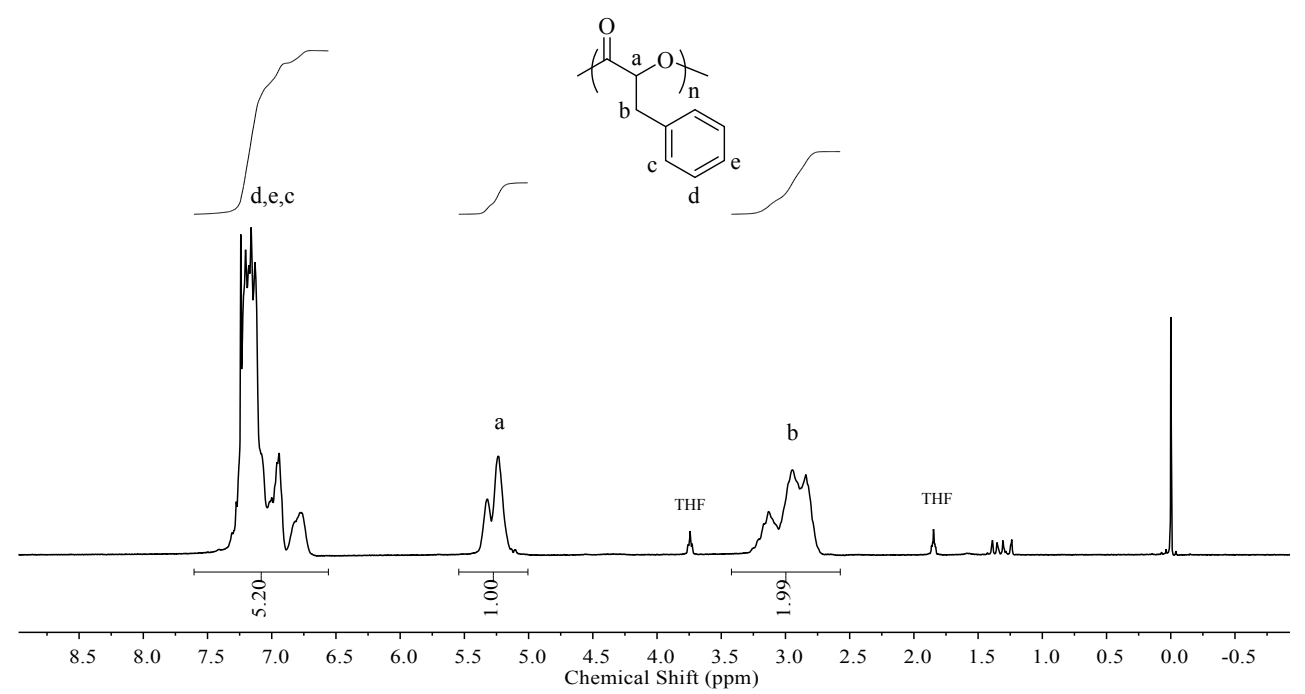

Figure S30. The ${ }^{1} \mathrm{H}$ NMR spectrum of the poly $\left(r a c\right.$-PheOCA) in $\mathrm{CDCl}_{3}$ (Table S1, entry 8). 


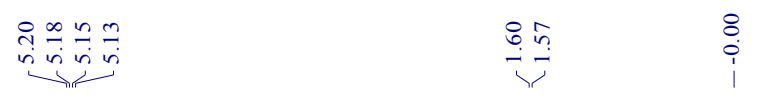<smiles>CC(=O)C(C)OC(C)(C)C</smiles>
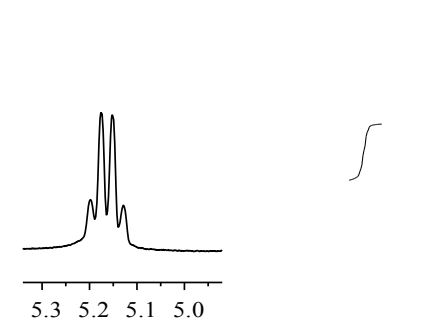

$$
\text { b }
$$
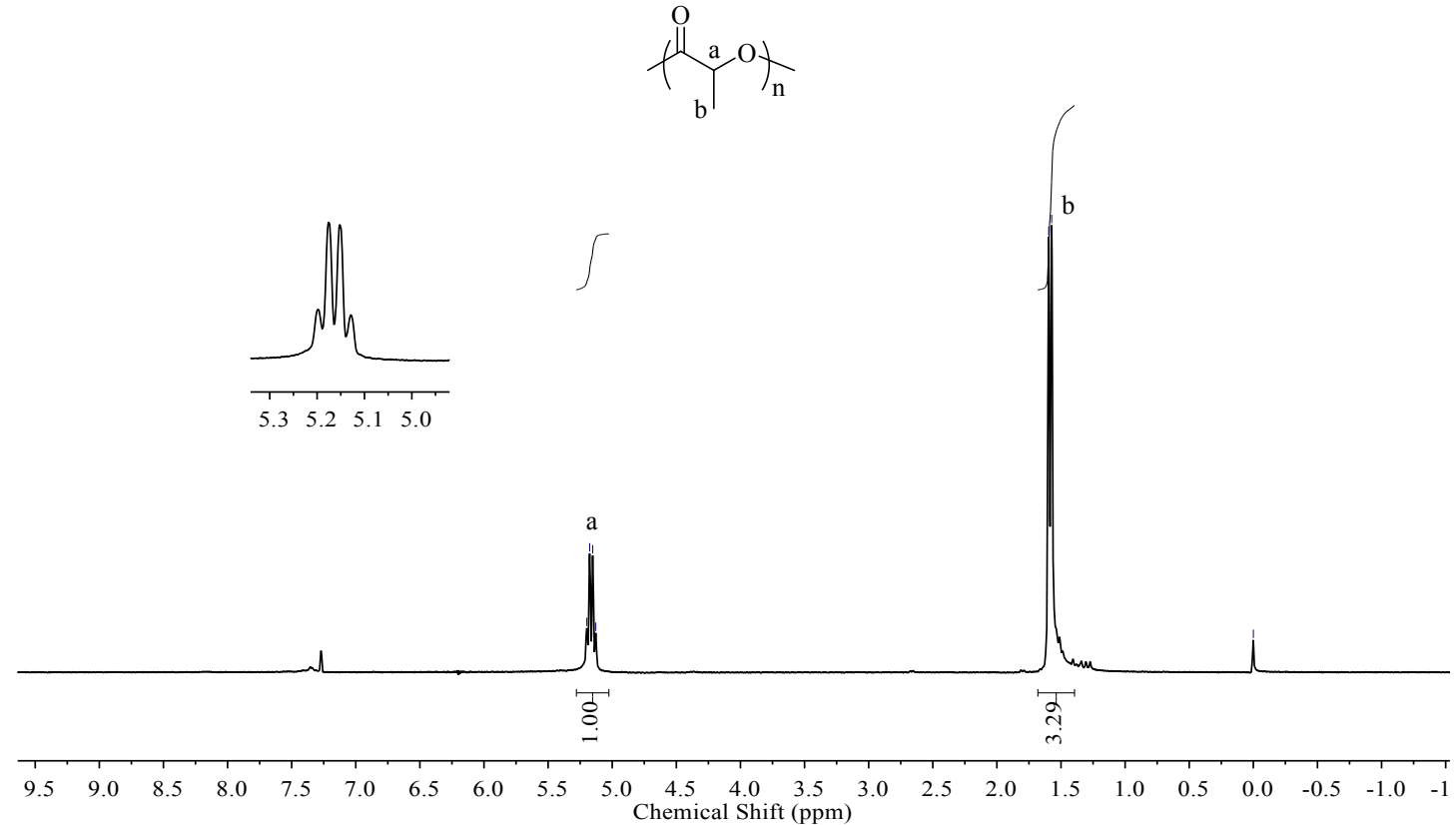

Figure S31. The ${ }^{1} \mathrm{H}$ NMR spectrum of the poly(L-LacOCA) in $\mathrm{CDCl}_{3}$ (Table S1, entry 5).

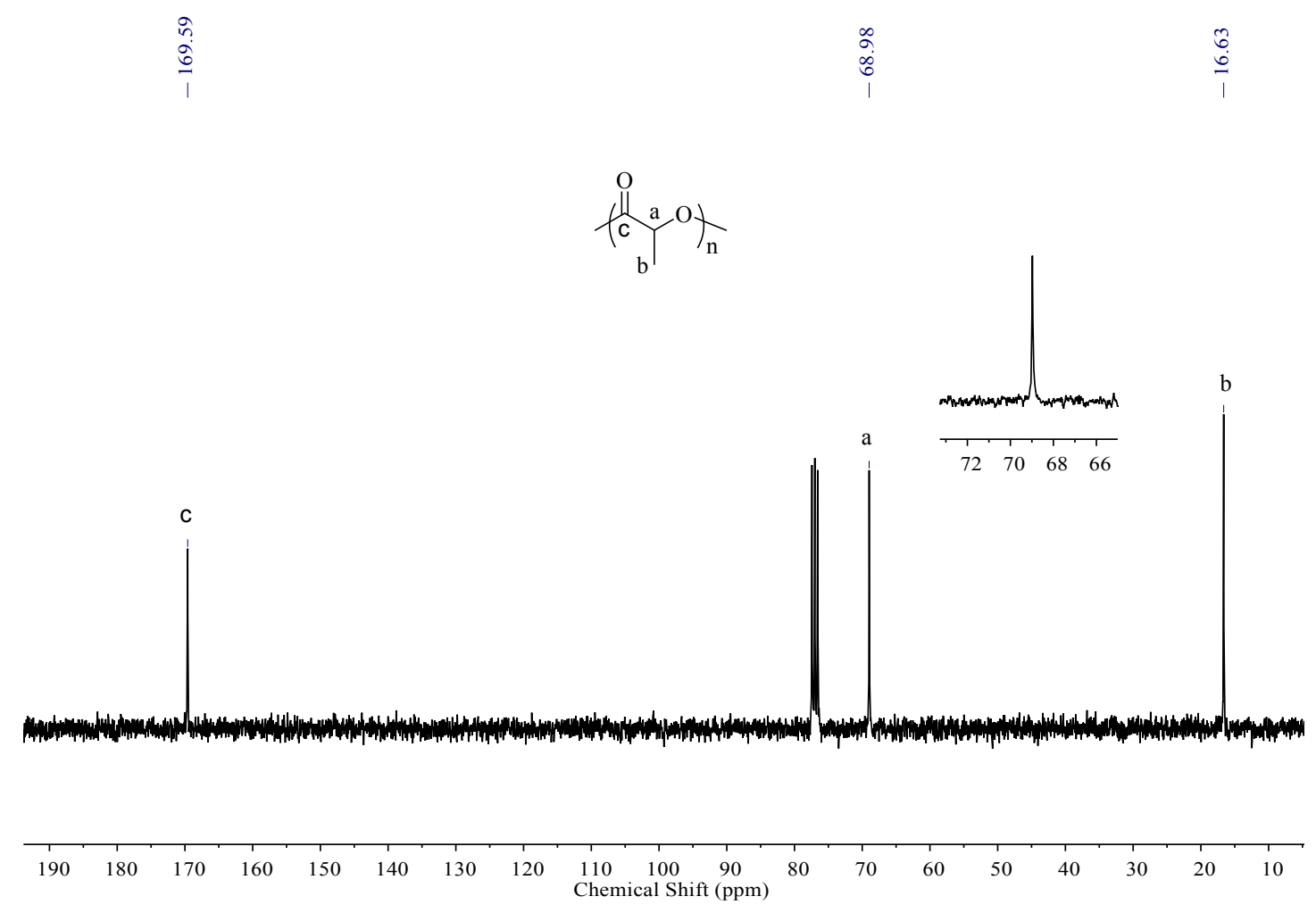

Figure S32. The ${ }^{13} \mathrm{C}$ NMR spectrum of the poly(L-LacOCA) in $\mathrm{CDCl}_{3}$ (Table S1, entry 5). 


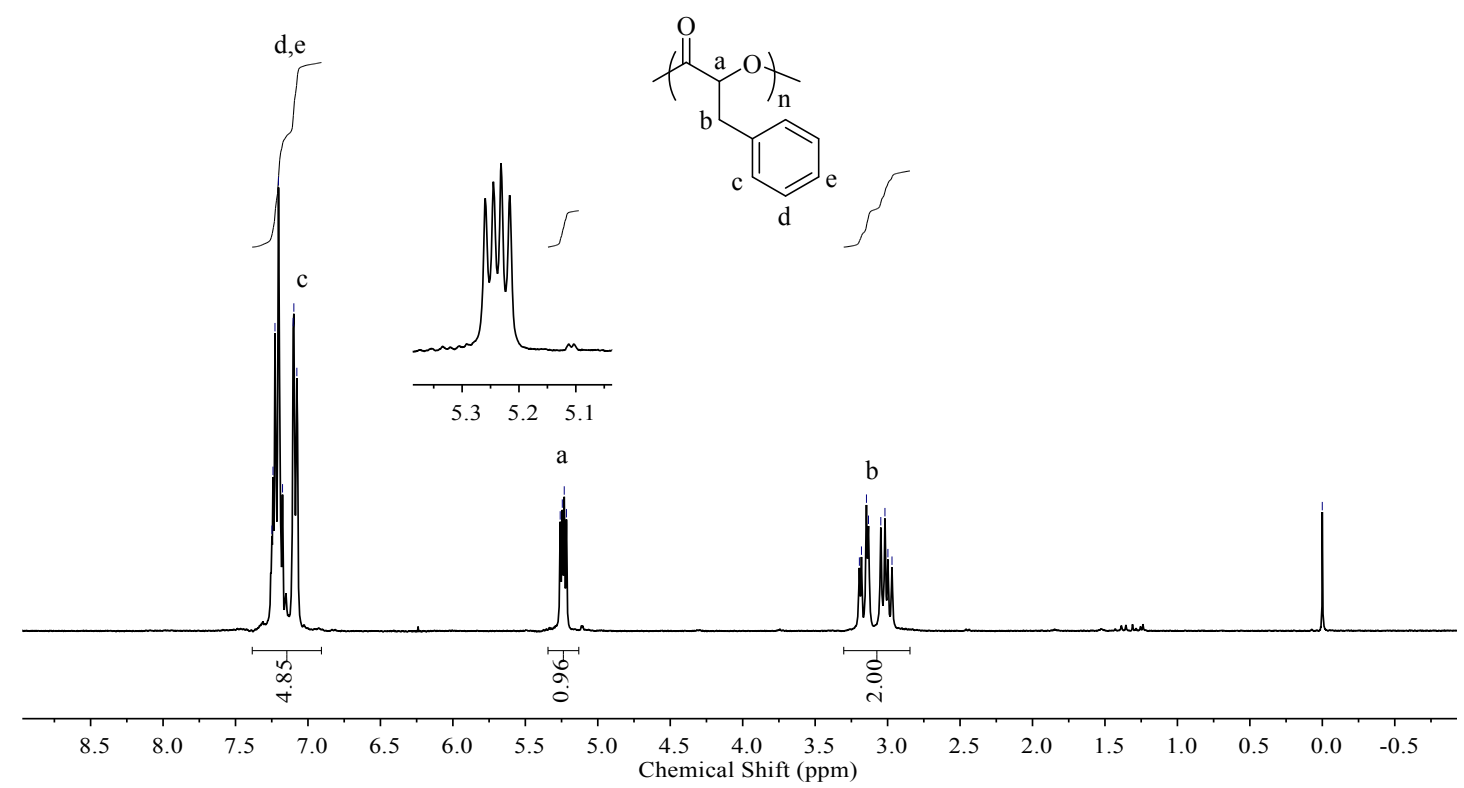

Figure S33. The ${ }^{1} \mathrm{H}$ NMR spectrum of the poly(L-PheOCA) in $\mathrm{CDCl}_{3}$ (Table S1, entry 7).

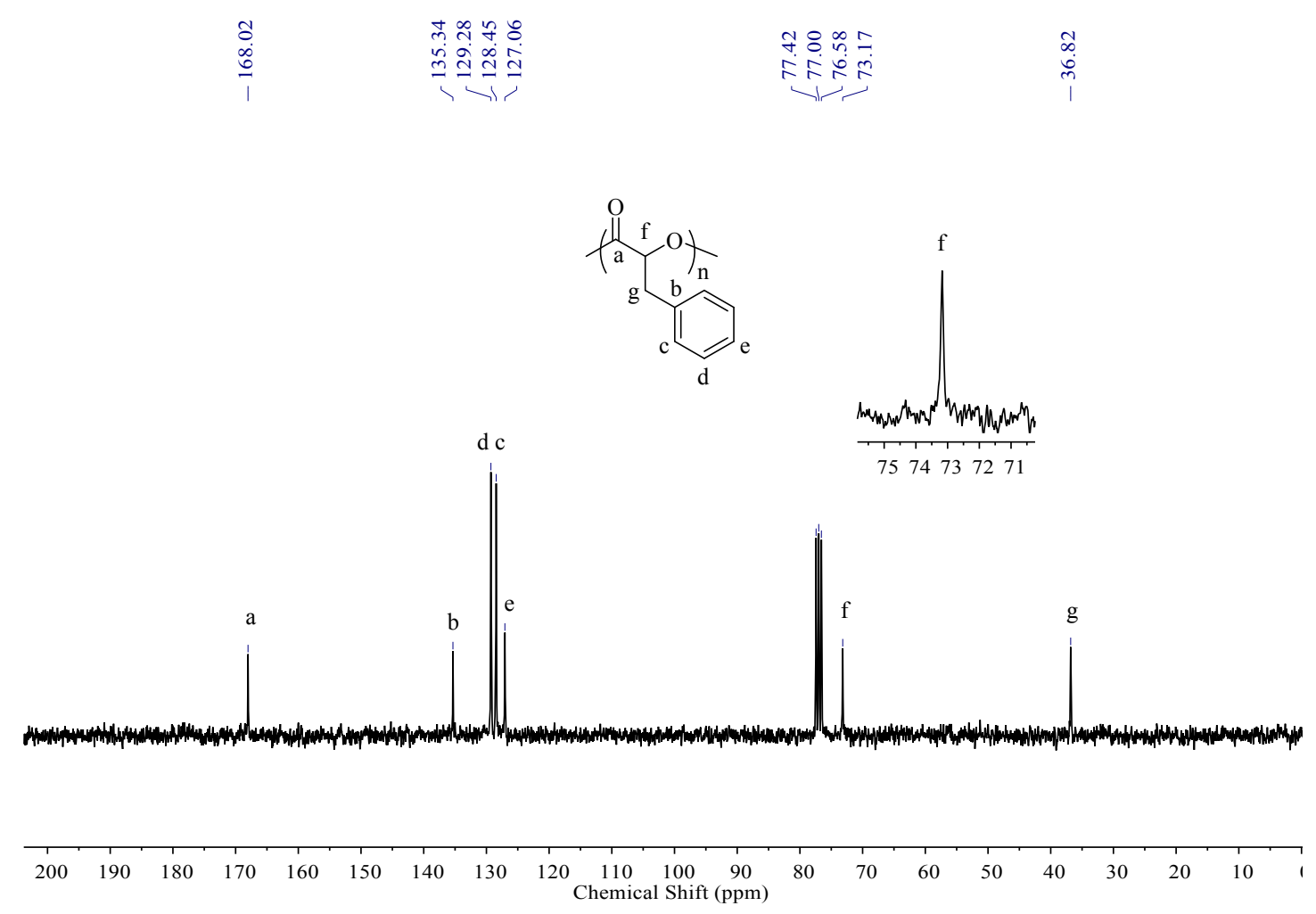

Figure S34. The ${ }^{13} \mathrm{C}$ NMR spectrum of the poly(L-PheOCA) in $\mathrm{CDCl}_{3}$ (Table S1, entry 7). 


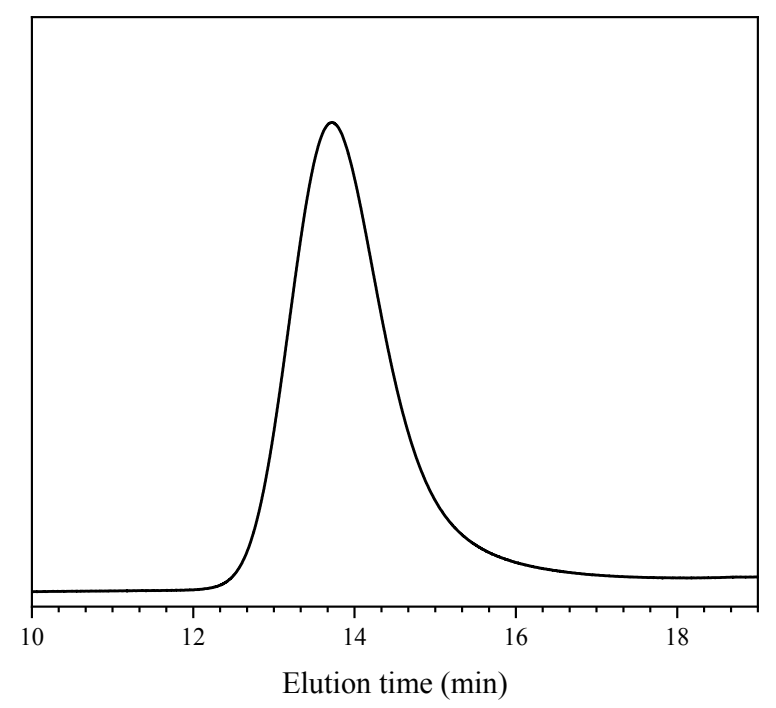

Figure S37. The GPC trance PMA-100L-100L polymer samples obtained from Table S1, entry 2. $\left(M_{\mathrm{n}}=\right.$ 24900, $Ð=1.18$ )

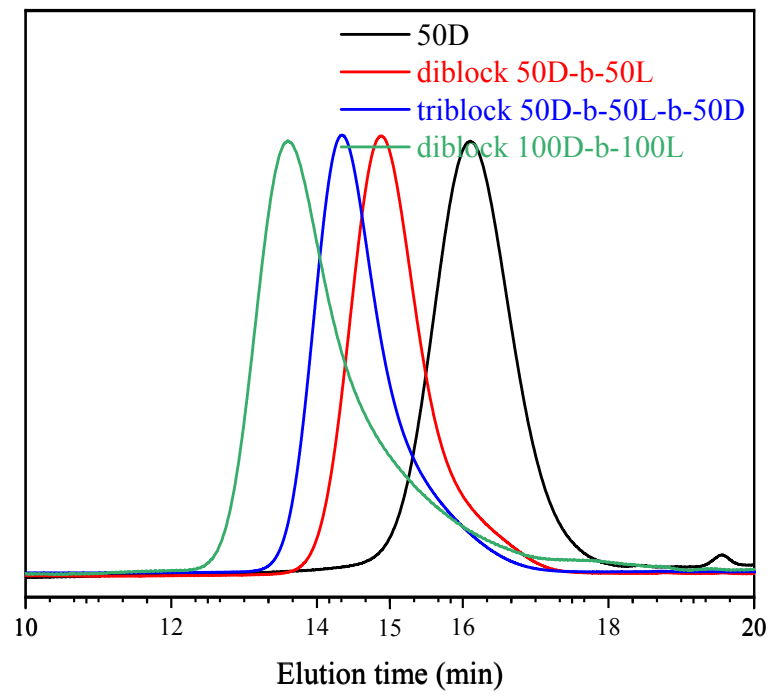

Figure S38. GPC trace of PMA-50L (black line), diblock PMA-50D-b-50L (red line), triblock PMA-50D-b-50L-50D (blue line), diblock PMA-100D-b-100L. 


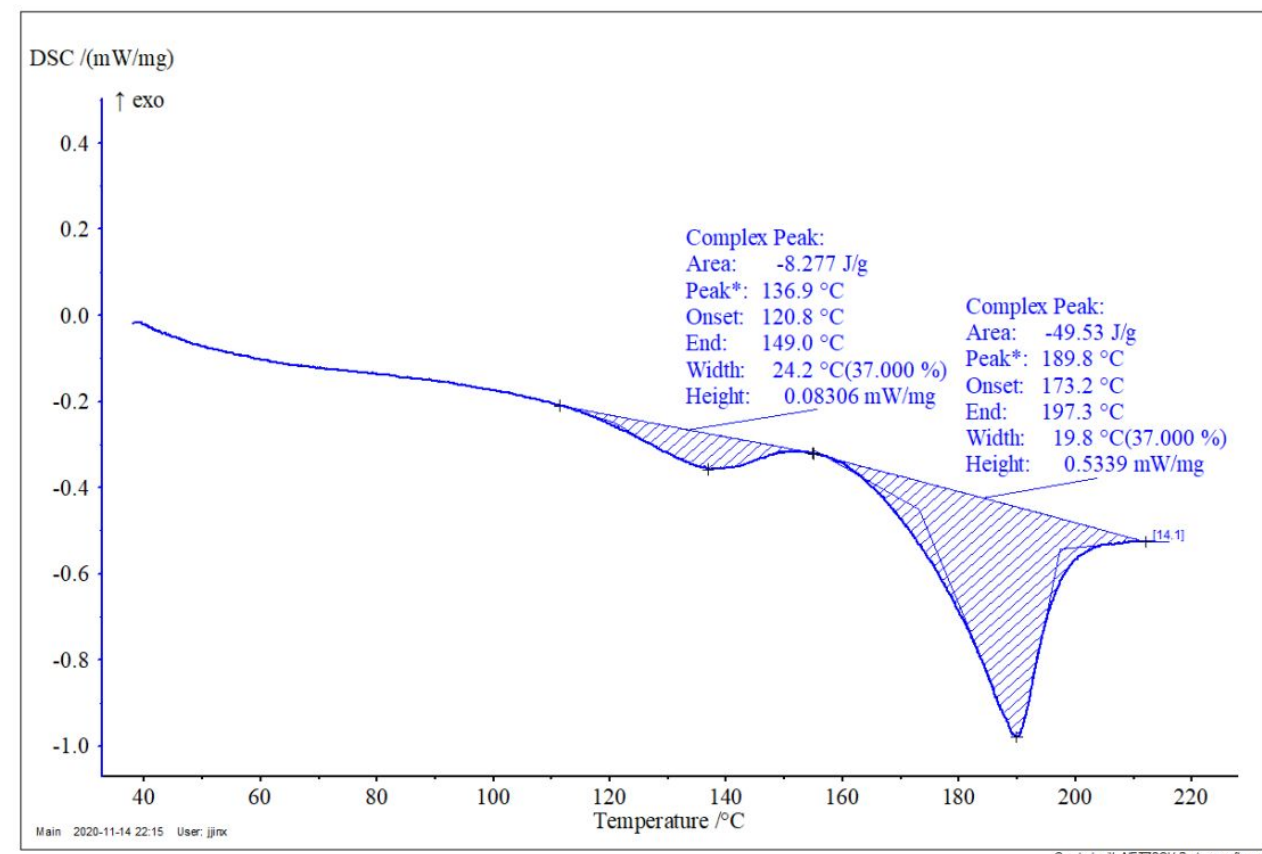

Figure S39. DSC first-heating scan curves of PMA-50L (Table1, entry 6). $T_{\mathrm{m} 1}=137{ }^{\circ} \mathrm{C}, T_{\mathrm{m} 2}=190{ }^{\circ} \mathrm{C}$.

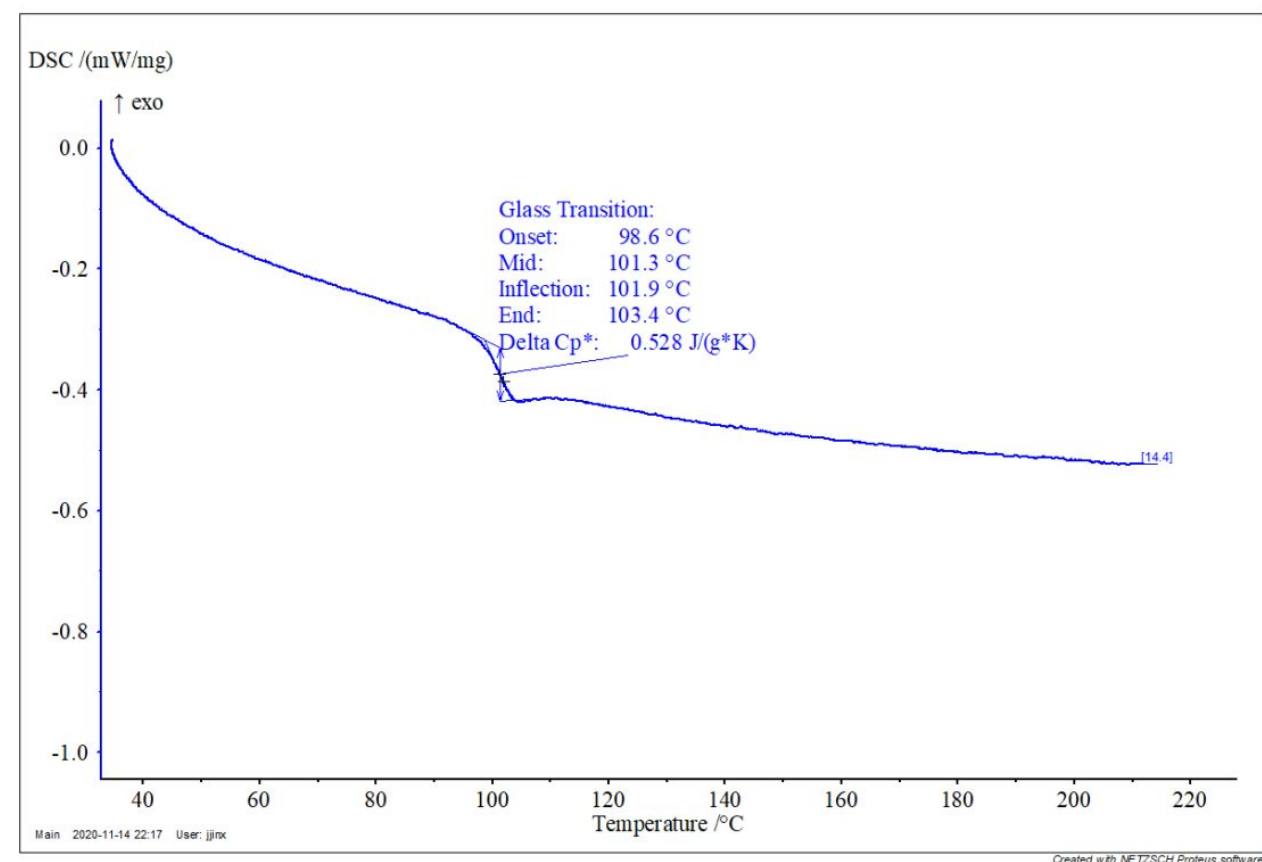

Figure S40. DSC second-heating scan curves of PMA-50L (Table1, entry 6). $T_{\mathrm{g}}=101{ }^{\circ} \mathrm{C}$. 


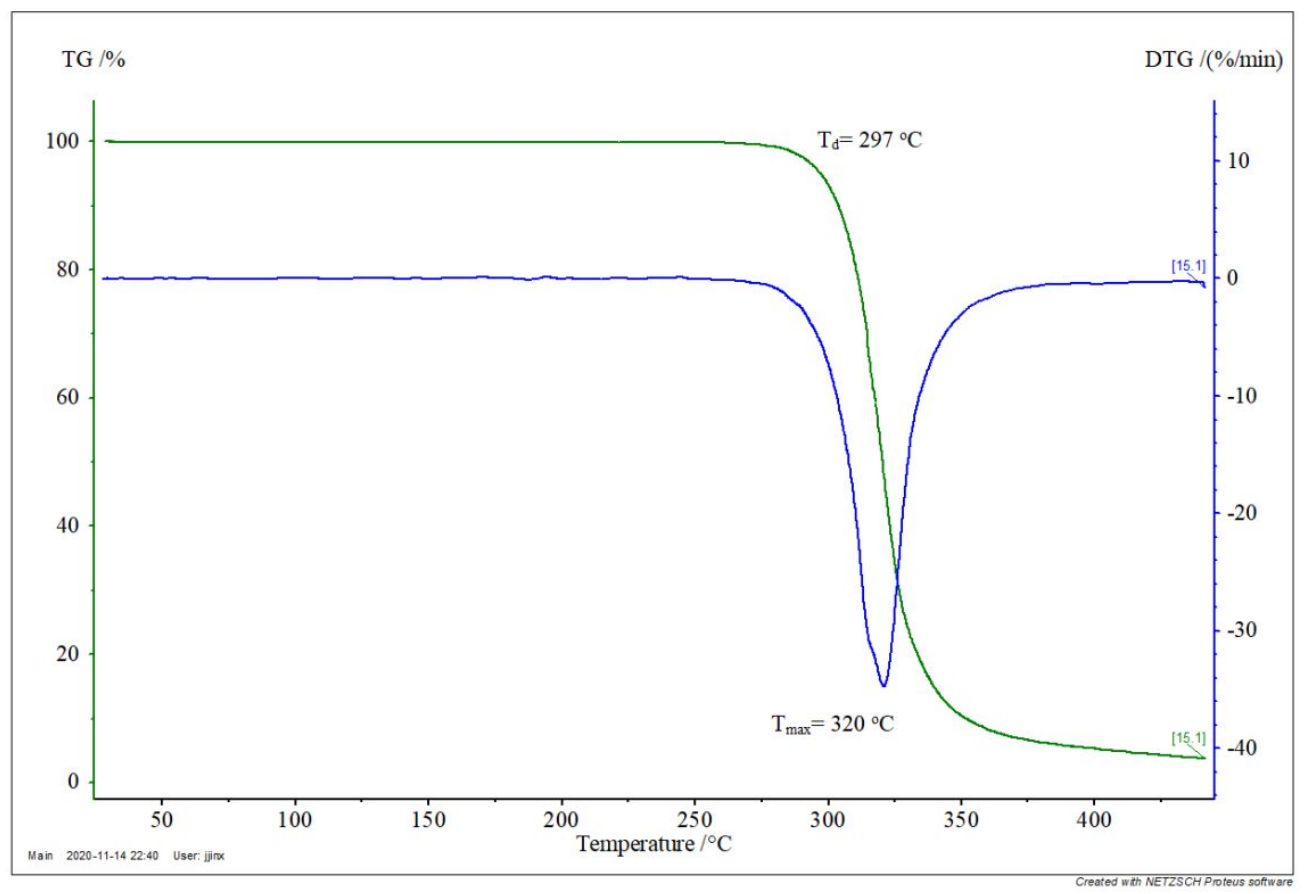

Figure S41. TGA curve of PMA-50L (Table1, entry 6). $T_{\mathrm{d}}(5 \%)=297^{\circ} \mathrm{C}, T_{\max }=320^{\circ} \mathrm{C}$.

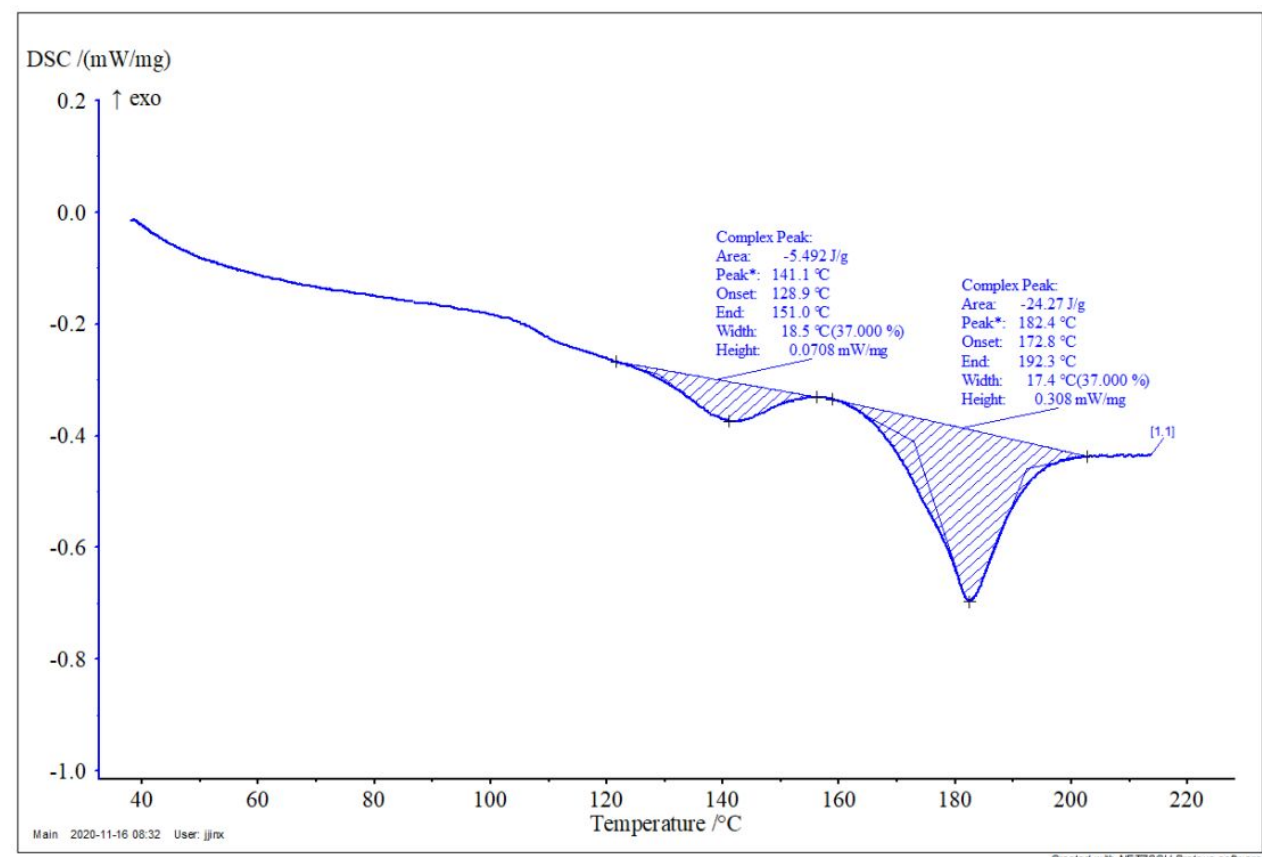

Figure S42. DSC first-heating scan curves of PMA-100L (Table1, entry 1). $T_{\mathrm{m} 1}=141{ }^{\circ} \mathrm{C}, T_{\mathrm{m} 2}=182^{\circ} \mathrm{C}$. 


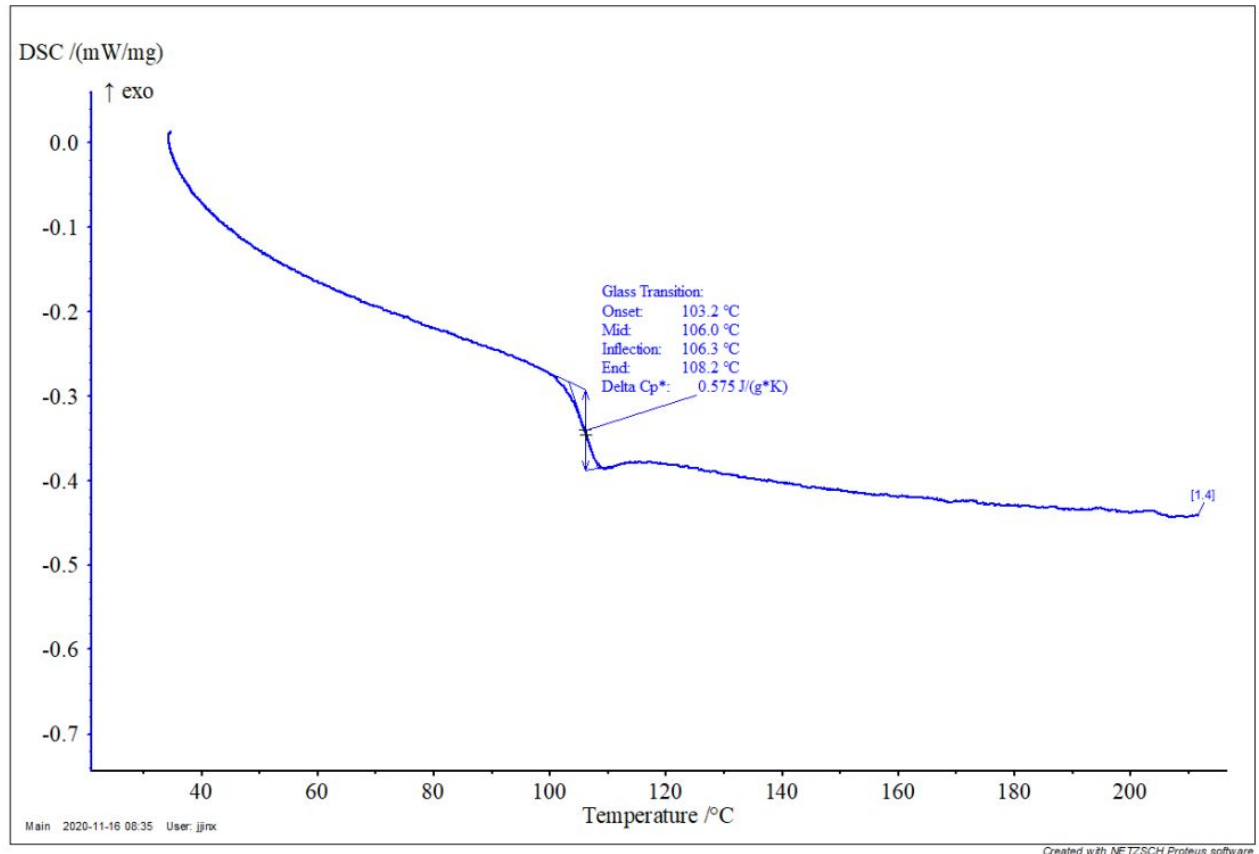

Figure S43. DSC second-heating scan curves of PMA-100L (Table1, entry 1). $T_{\mathrm{g}}=106^{\circ} \mathrm{C}$.

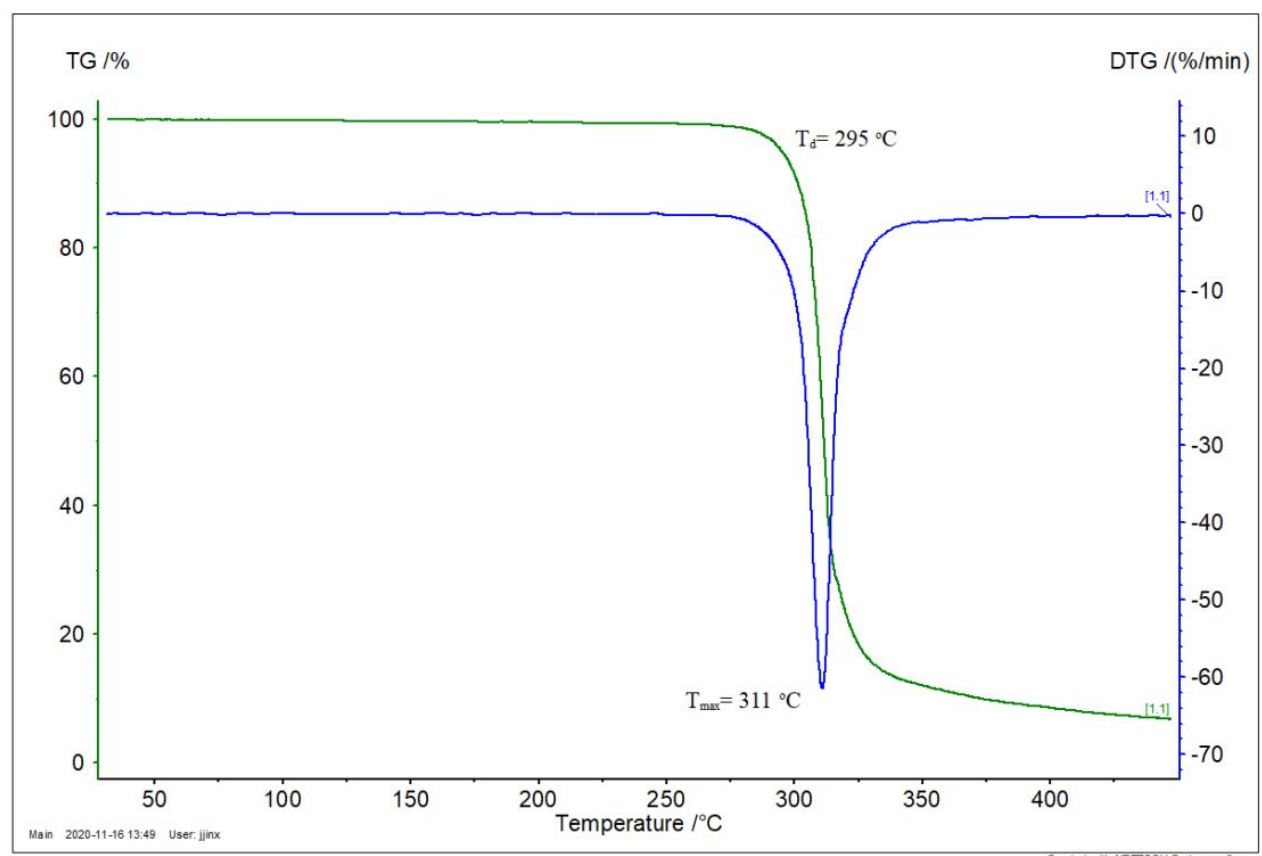

Figure S44. TGA curve of curves of PMA-100L (Table1, entry 1). $T_{\mathrm{d}}(5 \%)=295^{\circ} \mathrm{C}, T_{\max }=311^{\circ} \mathrm{C}$. 


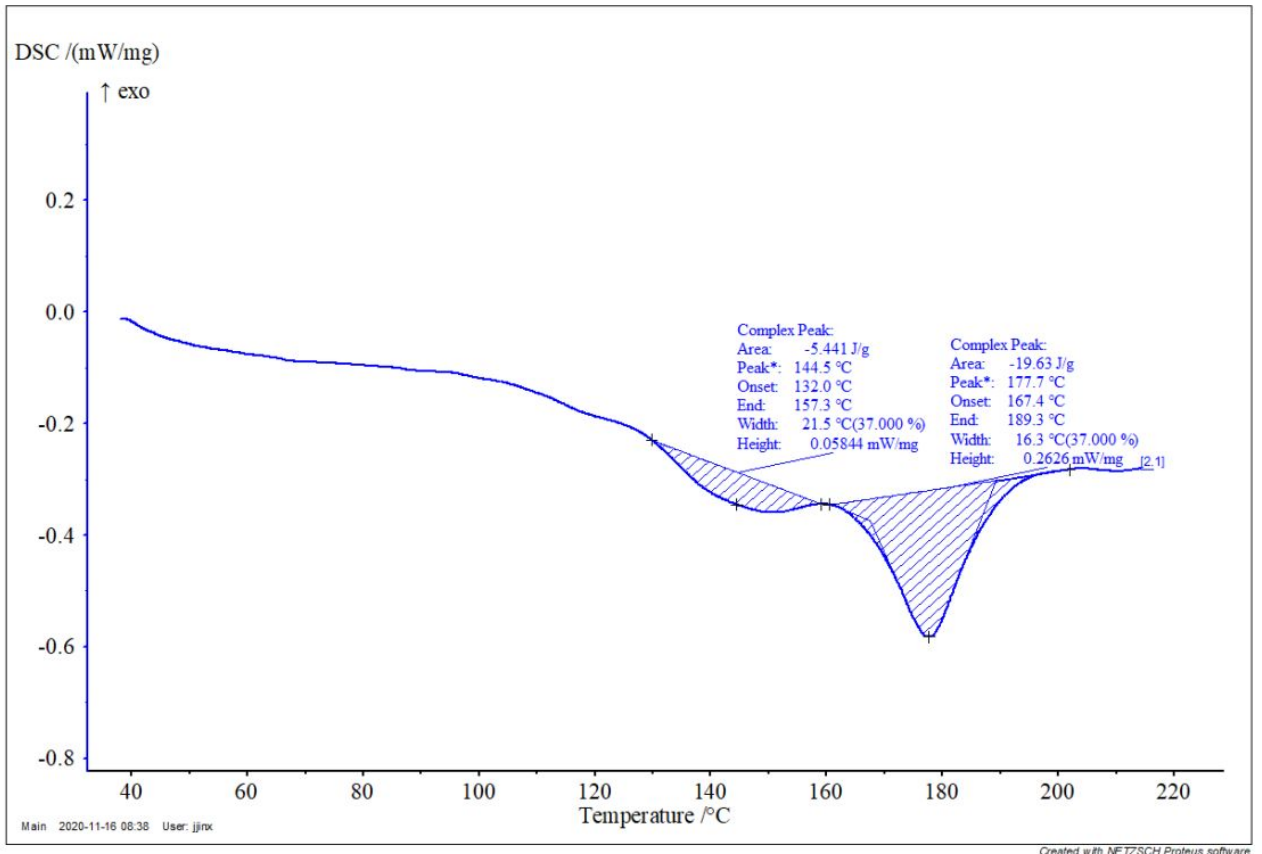

Figure S45. DSC first-heating scan curves of PMA-200L (Table1, entry 8). $T_{\mathrm{m} 1}=145{ }^{\circ} \mathrm{C}, T_{\mathrm{m} 2}=178{ }^{\circ} \mathrm{C}$.

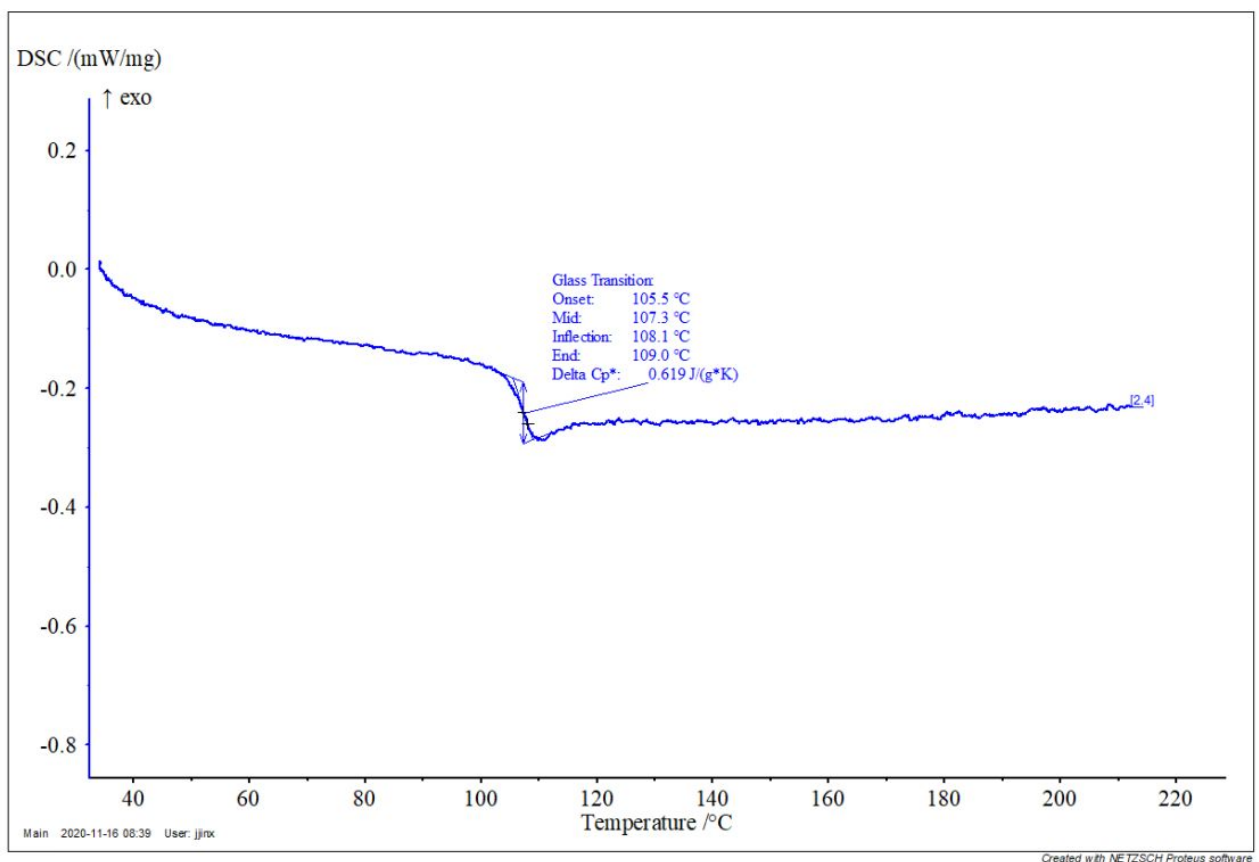

Figure S46. DSC second-heating scan curves of PMA-200L (Table1, entry 8). $T_{\mathrm{g}}=107^{\circ} \mathrm{C}$. 


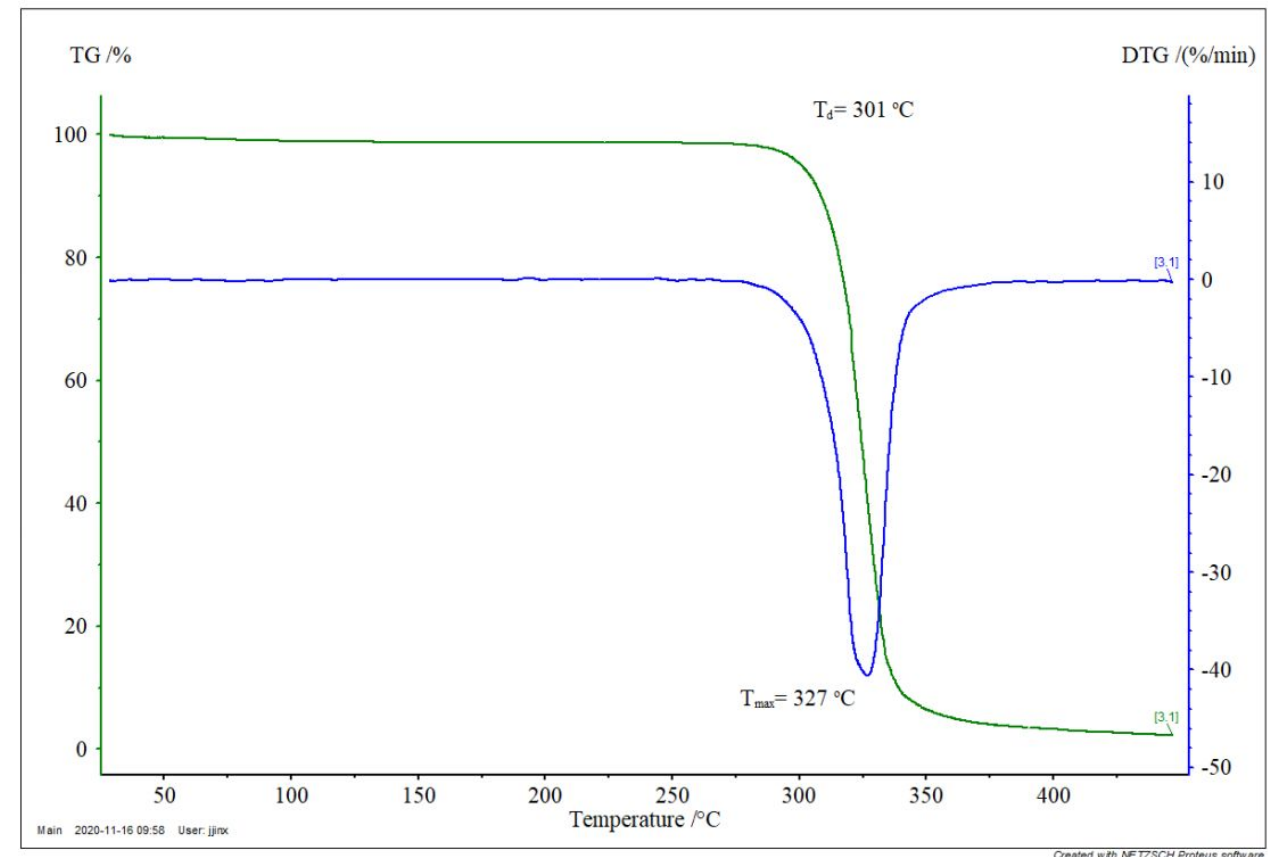

Figure S47. TGA curve of PMA-200L (Table1, entry 8). $T_{\mathrm{d}}(5 \%)=301{ }^{\circ} \mathrm{C}, T_{\max }=327^{\circ} \mathrm{C}$.

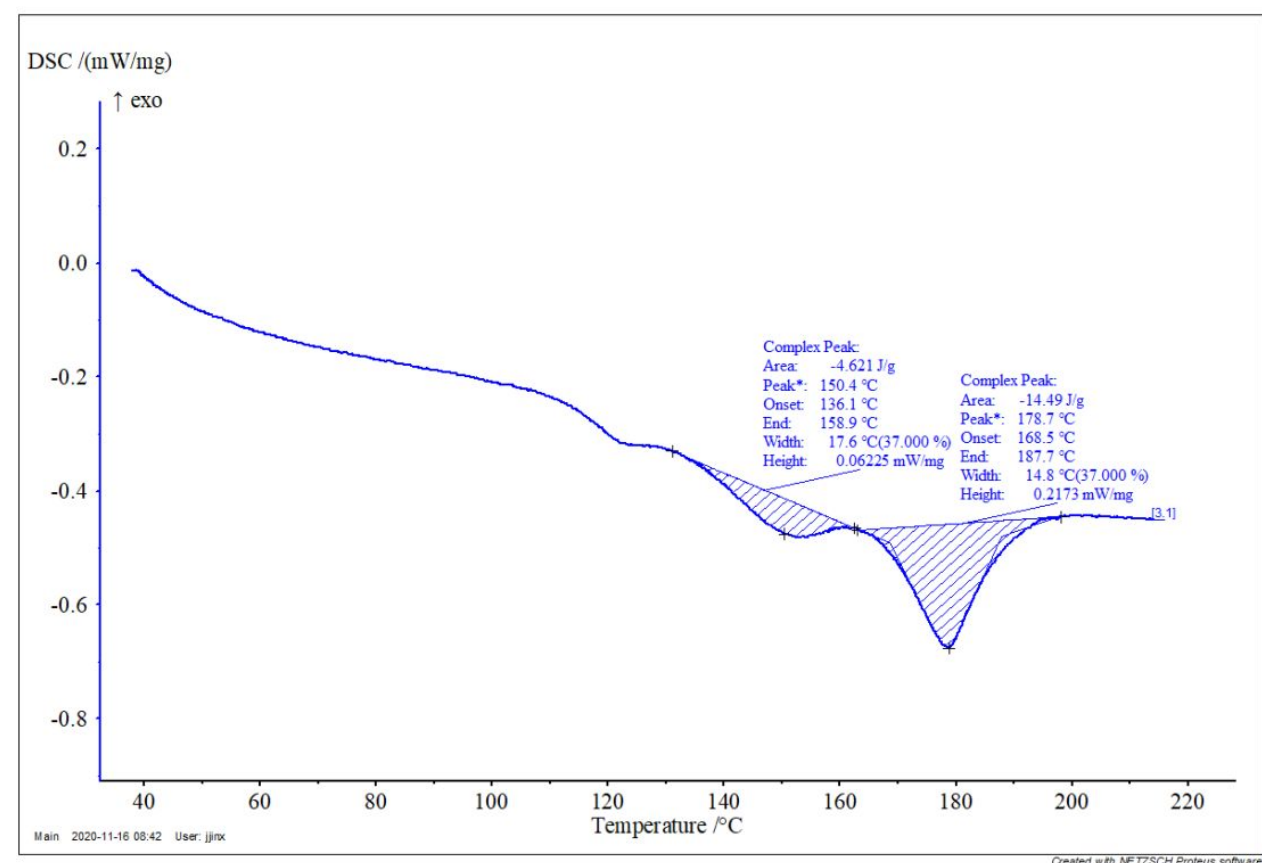

Figure S48. DSC first-heating scan curves of PMA-300L (Table1, entry 9). $T_{\mathrm{m} 1}=150{ }^{\circ} \mathrm{C}, T_{\mathrm{m} 2}=179^{\circ} \mathrm{C}$. 


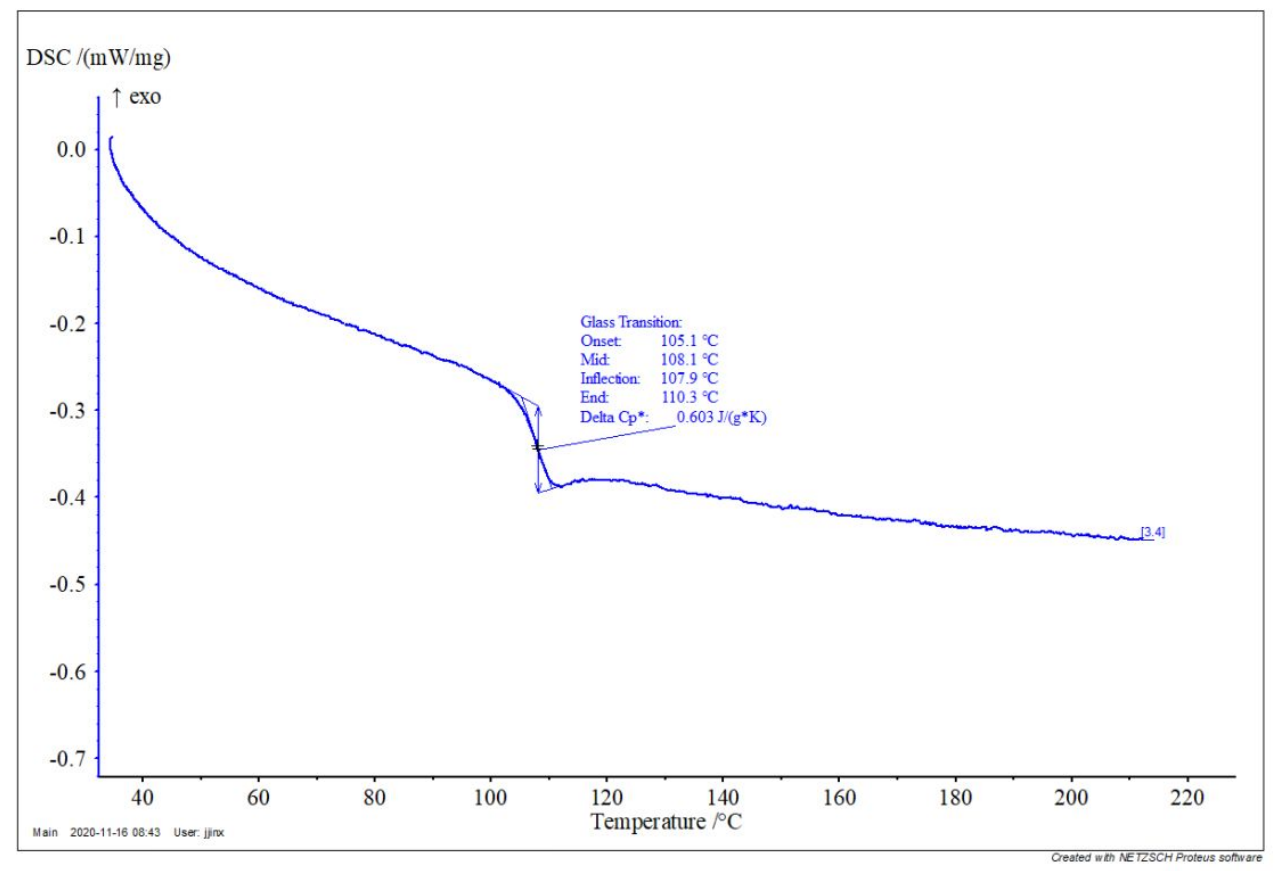

Figure S49. DSC second-heating scan curves of PMA-300L (Table1, entry 9). $T_{\mathrm{g}}=108^{\circ} \mathrm{C}$.

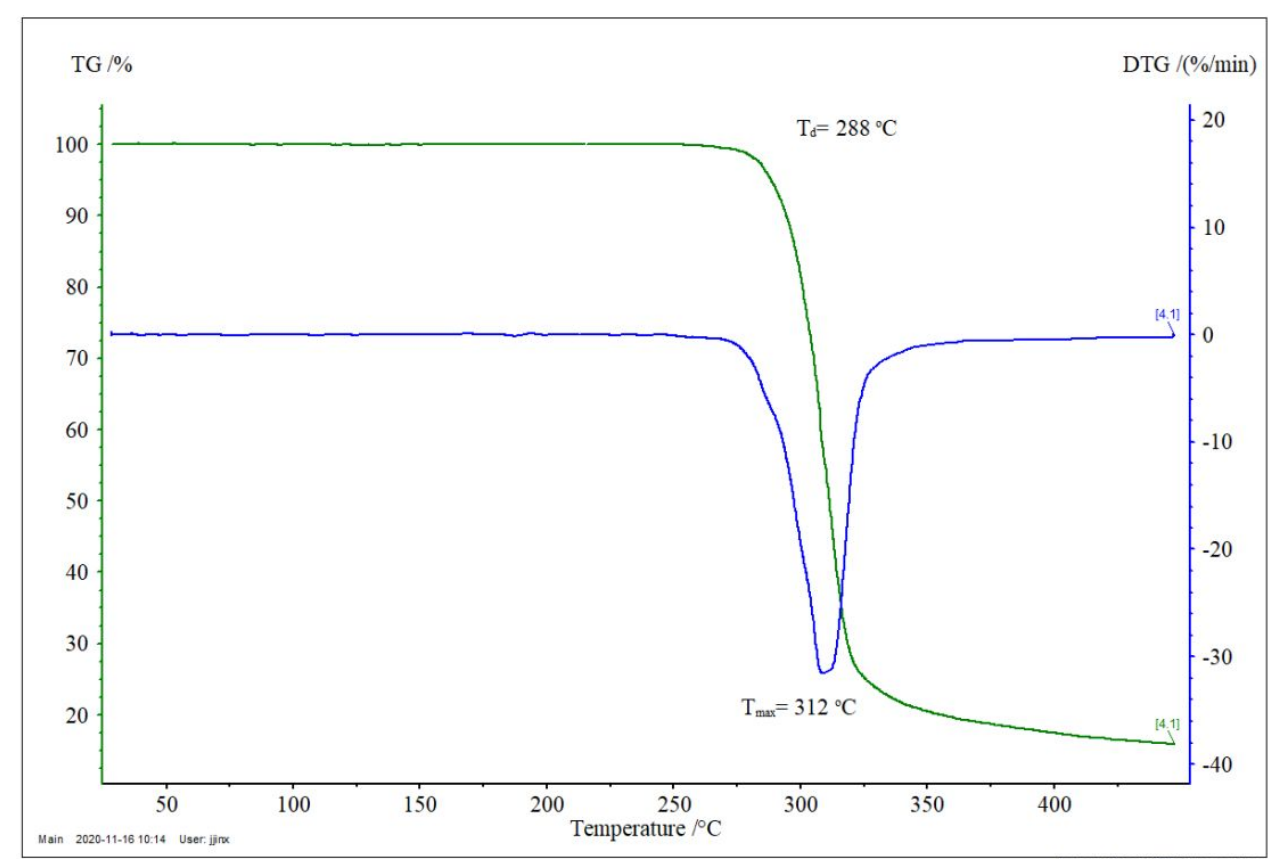

Figure S50. TGA curve of PMA-300L (Table1, entry 9). $T_{\mathrm{d}}(5 \%)=288^{\circ} \mathrm{C}, T_{\max }=312{ }^{\circ} \mathrm{C}$. 


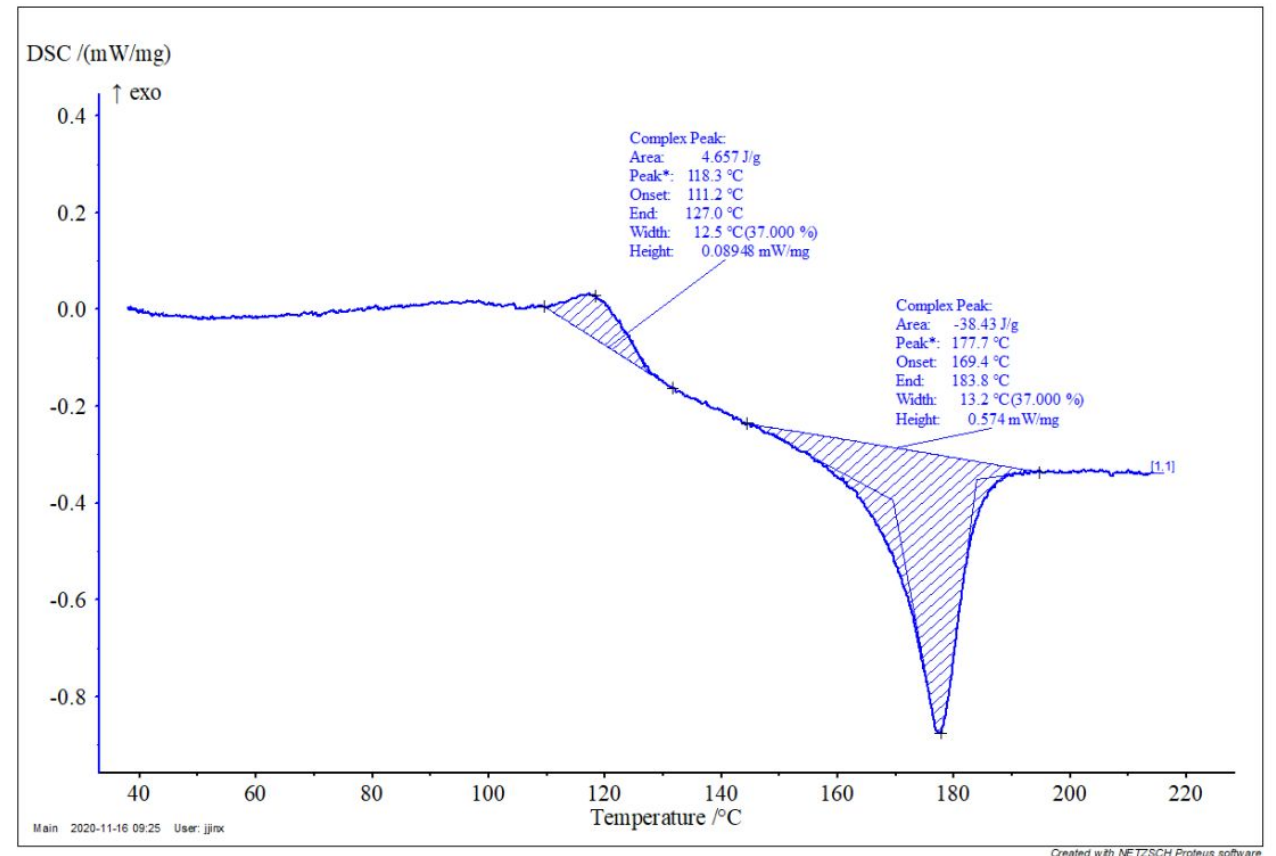

Figure S51. DSC first-heating scan curves of diblock PMA-50D-b-50L. (Table2, entry 1). $T_{\mathrm{c}}=118^{\circ} \mathrm{C}, T_{\mathrm{m}}=$ $178^{\circ} \mathrm{C}$.

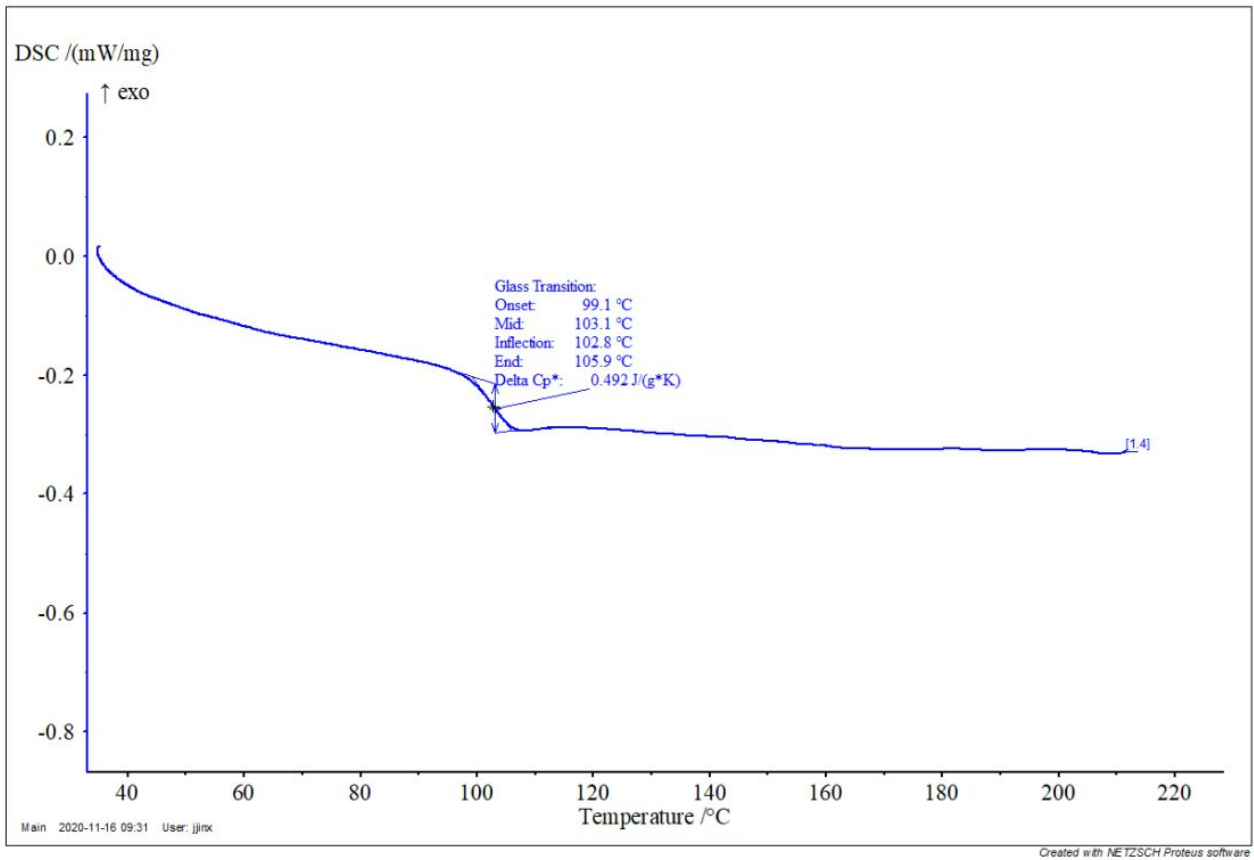

Figure S52. DSC second heating scan curves of diblock PMA-50D-b-50L. (Table2, entry 1). $T_{\mathrm{g}}=103{ }^{\circ} \mathrm{C}$. 


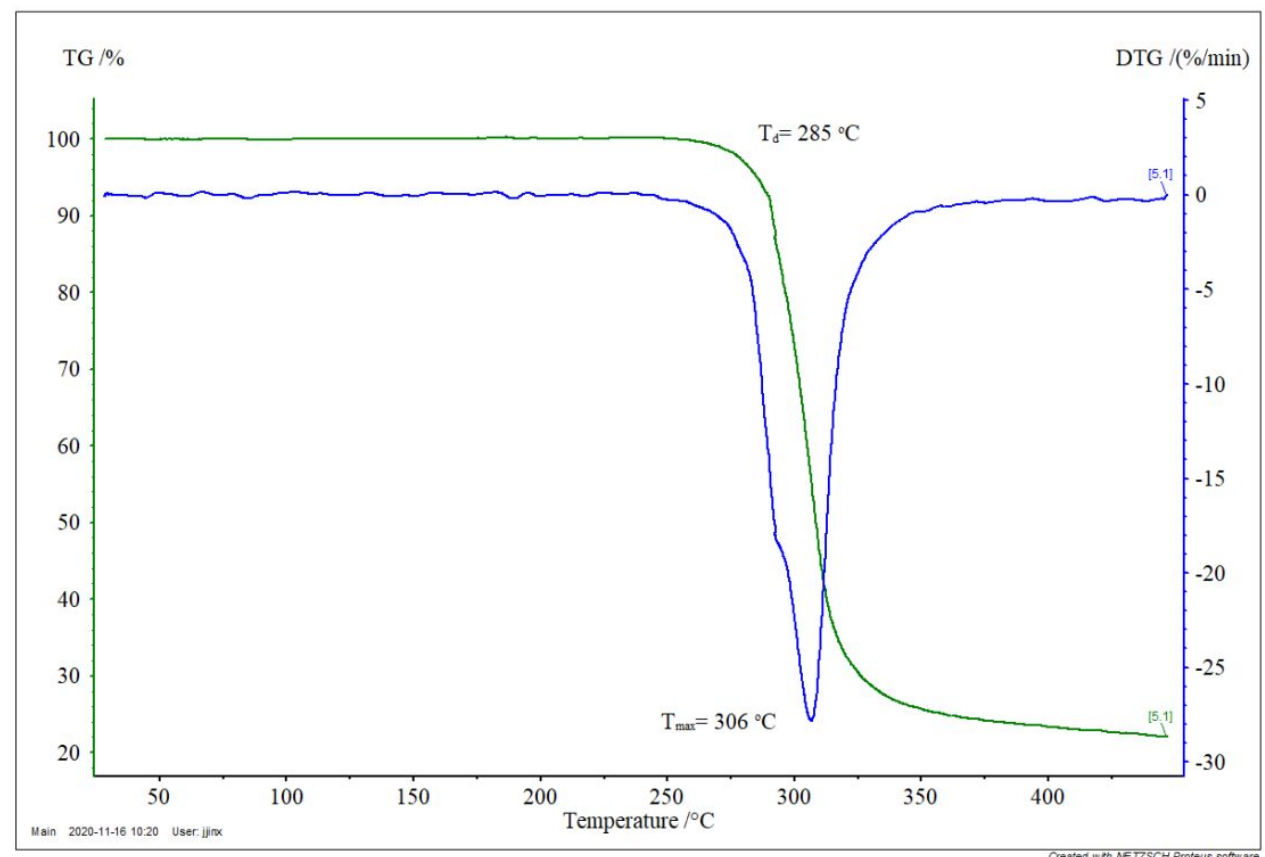

Figure S53. TGA curve of diblock PMA-50D-b-50L. (Table2, entry 1). $T_{\mathrm{d}}(5 \%)=285{ }^{\circ} \mathrm{C}, T_{\max }=306^{\circ} \mathrm{C}$.

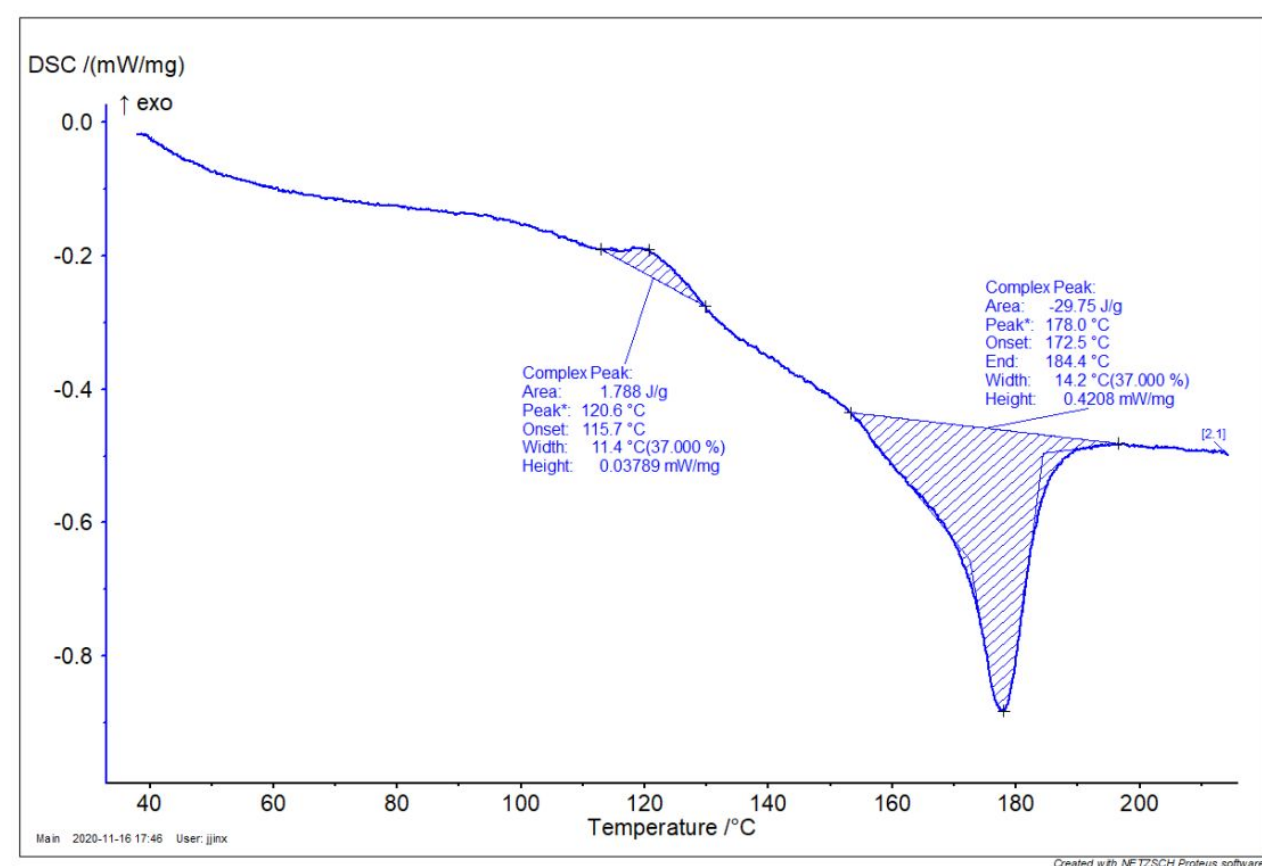

Figure S54. DSC first-heating scan curves of diblock PMA-50L-b-50D. (Table2, entry 2). $T_{\mathrm{c}}=121^{\circ} \mathrm{C}, T_{\mathrm{m}}=$ $178^{\circ} \mathrm{C}$. 


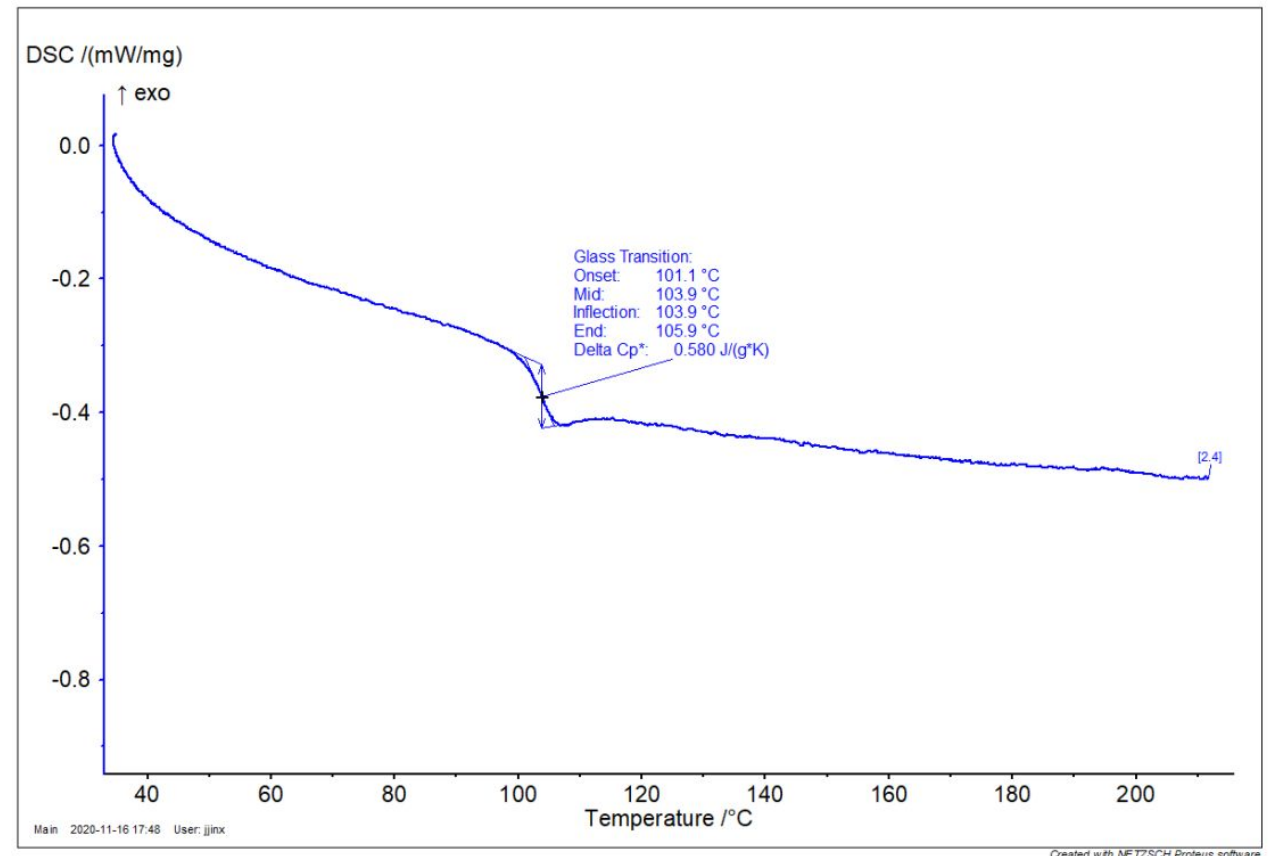

Figure S55. DSC second heating scan curves of diblock PMA-50L-b-50D. (Table2, entry 2 ). $T_{\mathrm{g}}=104^{\circ} \mathrm{C}$.

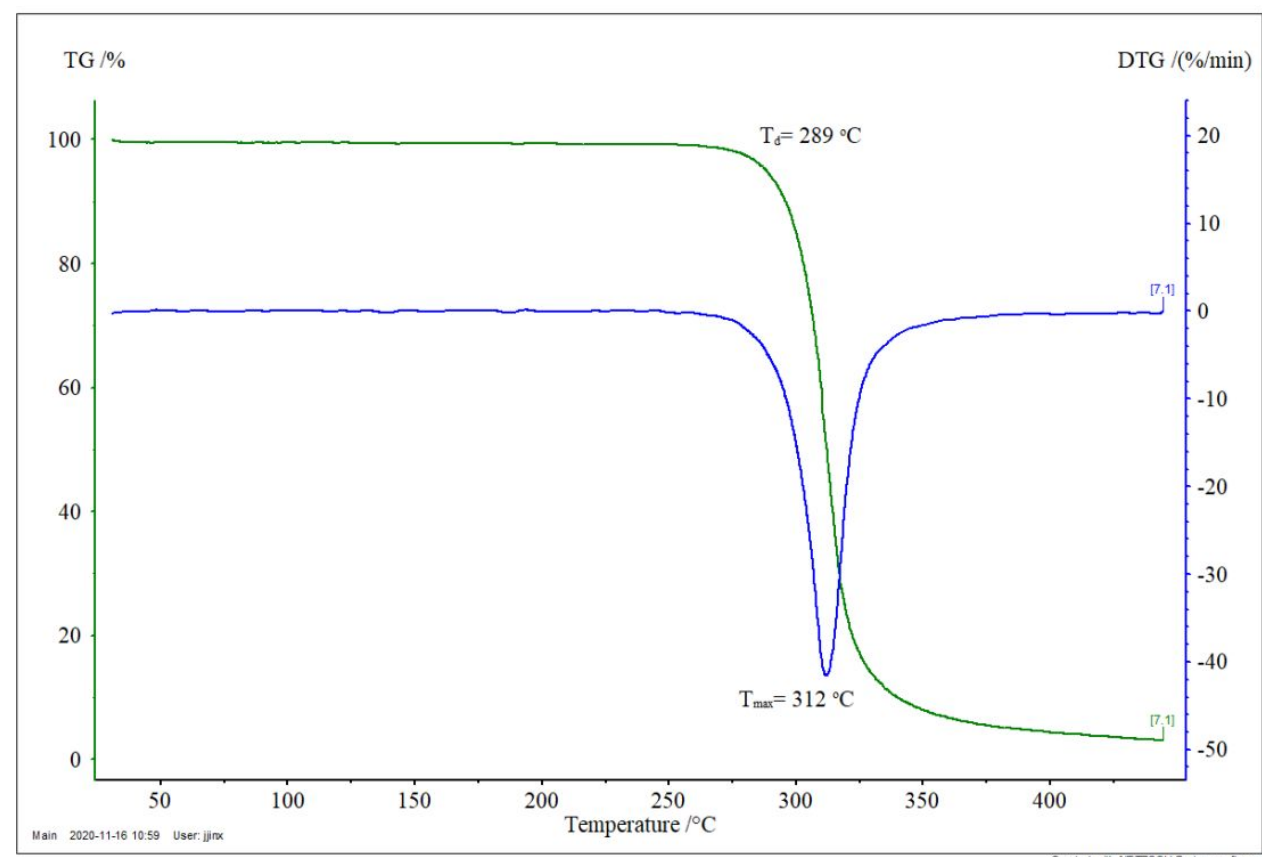

Figure S56. TGA curve of diblock PMA-50L-b-50D. (Table2, entry 2).. $T_{\mathrm{d}}(5 \%)=289{ }^{\circ} \mathrm{C}, T_{\max }=312{ }^{\circ} \mathrm{C}$. 


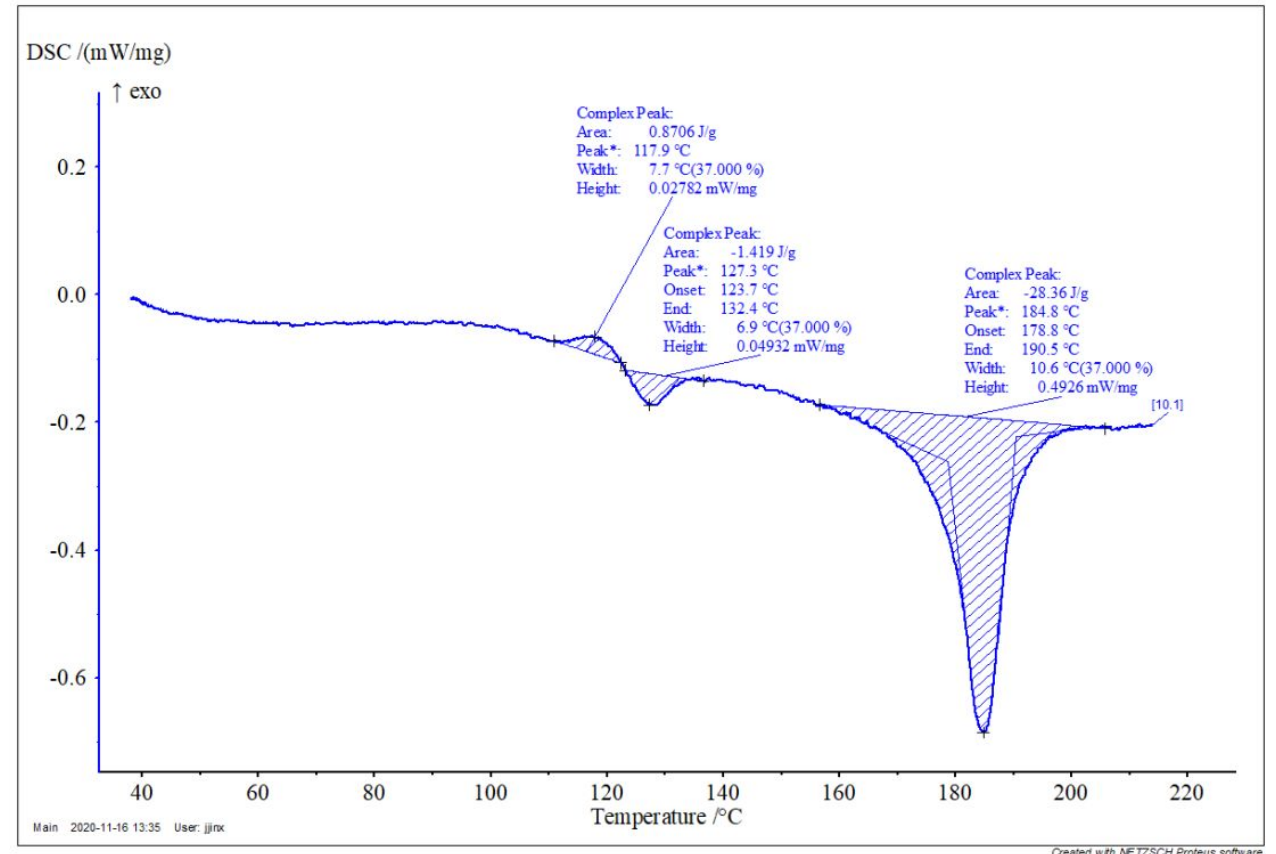

Figure S57. DSC first-heating scan curves of the mixture of poly(L-manOCA) $\left(M_{\mathrm{n}}=11400 \mathrm{~g} / \mathrm{mol}, Ð=1.14\right)$ and poly(D-manOCA) $\left(M_{\mathrm{n}}=11000 \mathrm{~g} / \mathrm{mol}, Ð=1.13\right), T_{\mathrm{c}}=118{ }^{\circ} \mathrm{C}, T_{\mathrm{m} 1}=127{ }^{\circ} \mathrm{C} T_{\mathrm{m} 2}=185^{\circ} \mathrm{C}$.

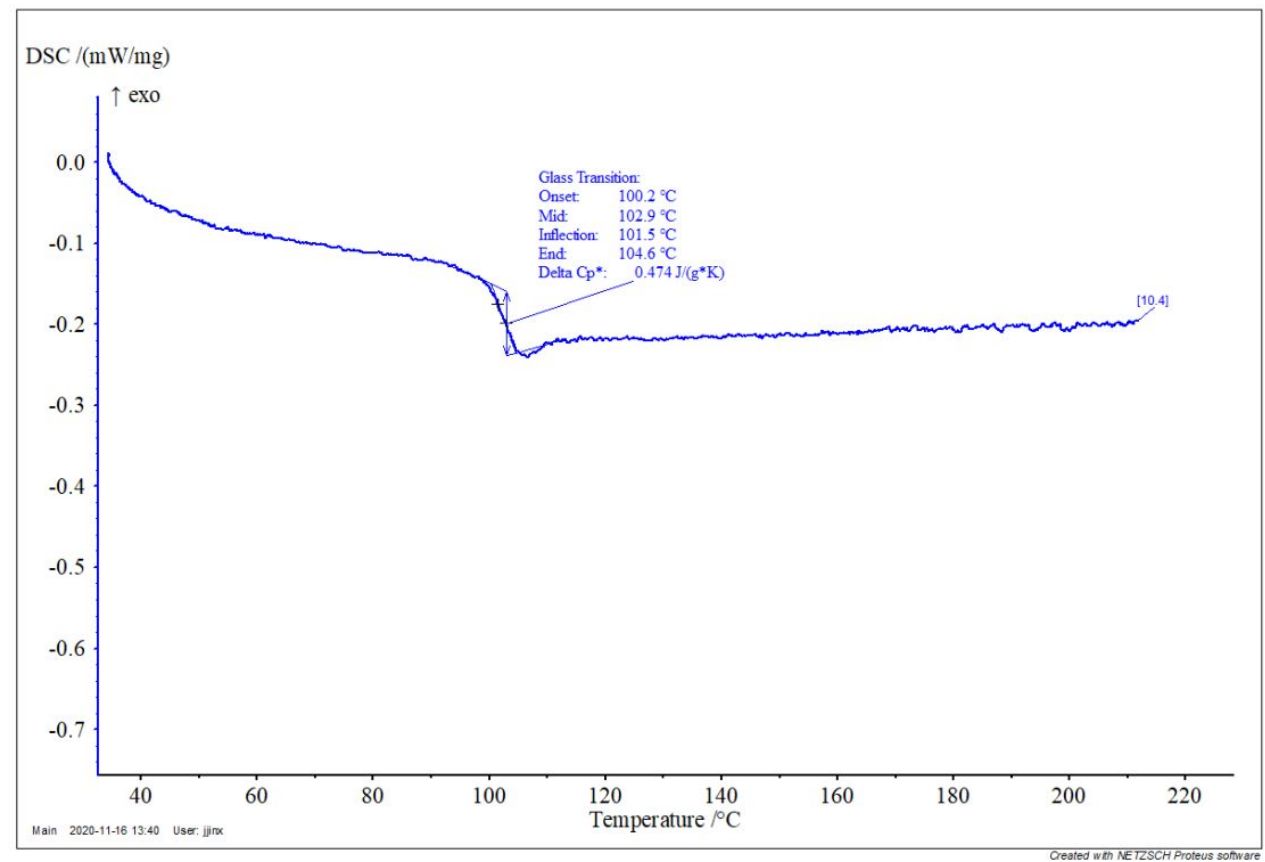

Figure S58. DSC second heating scan curves of the mixture of poly(L-manOCA $)\left(M_{\mathrm{n}}=11400 \mathrm{~g} / \mathrm{mol}, Ð=\right.$ $1.14)$ and poly(D-manOCA) $\left(M_{\mathrm{n}}=11000 \mathrm{~g} / \mathrm{mol}, Ð=1.13\right), T_{\mathrm{g}}=103^{\circ} \mathrm{C}$. 


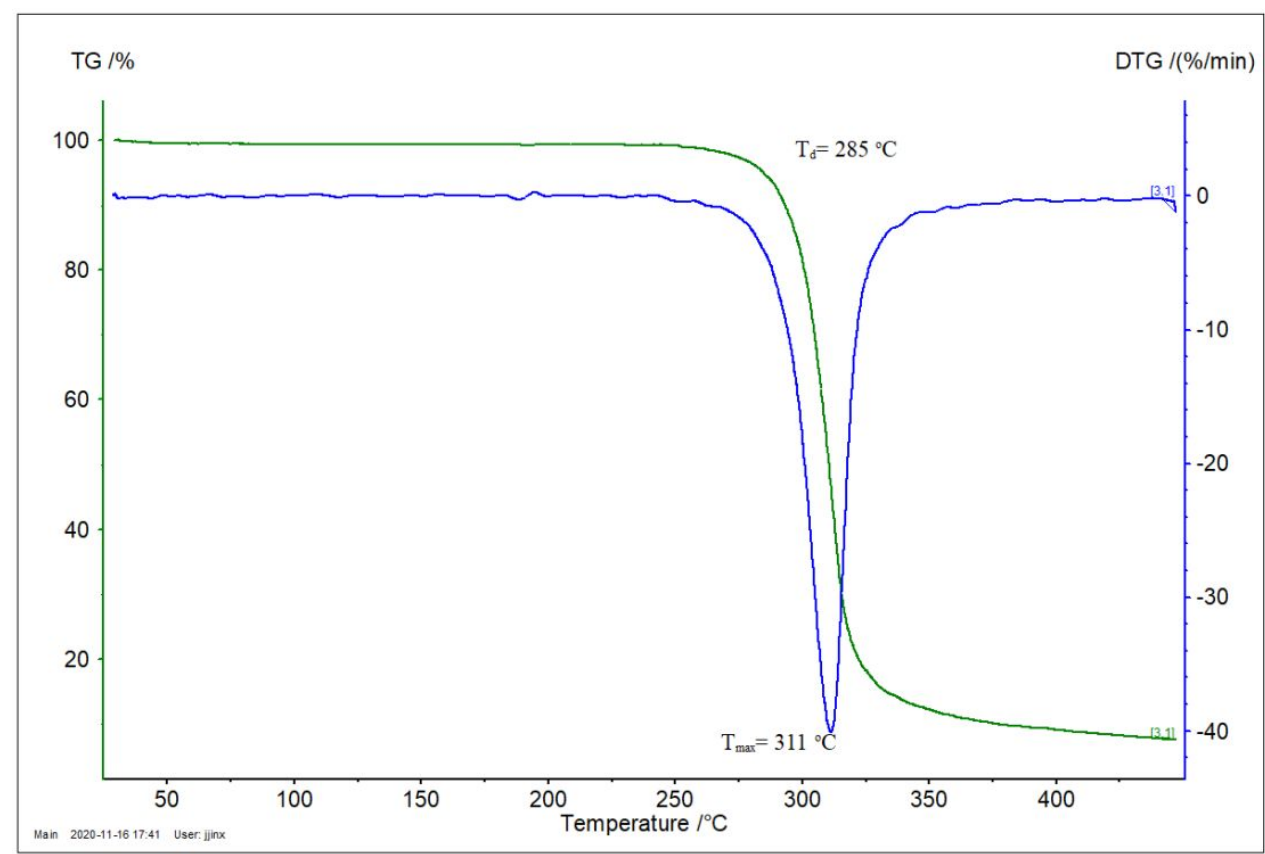

Figure S59. TGA curve of the mixture of poly(L-manOCA) $\left(M_{\mathrm{n}}=11400 \mathrm{~g} / \mathrm{mol}, Ð=1.14\right)$ and $\operatorname{poly}(\mathrm{D}-\mathrm{manOCA})\left(M_{\mathrm{n}}=11000 \mathrm{~g} / \mathrm{mol}, Ð=1.13\right) . T_{\mathrm{d}}(5 \%)=285^{\circ} \mathrm{C}, T_{\max }=311^{\circ} \mathrm{C}$.

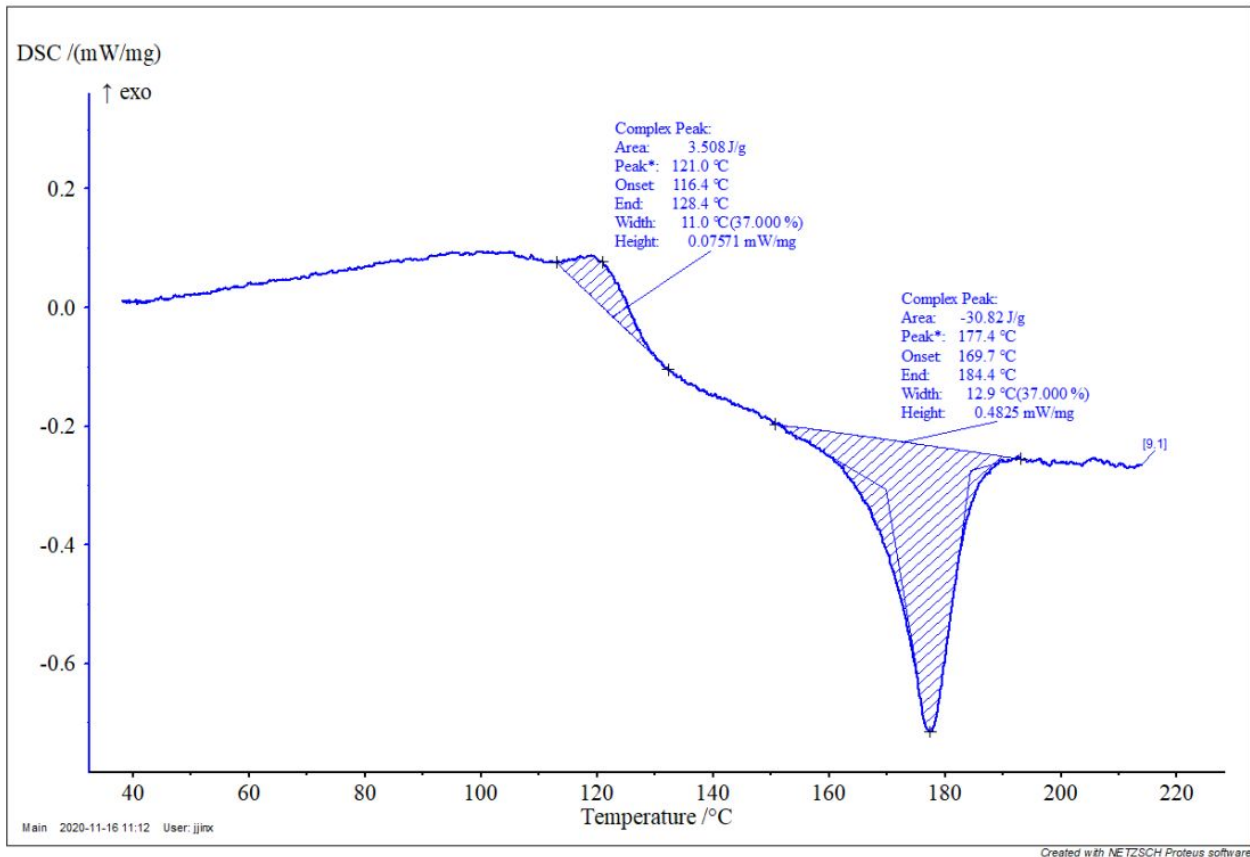

Figure S60. DSC first-heating scan curves of diblock PMA-100D-b-100L. (Table2, entry 3 ). $T_{\mathrm{c}}=121^{\circ} \mathrm{C}, T_{\mathrm{m}}$ $=177^{\circ} \mathrm{C}$. 


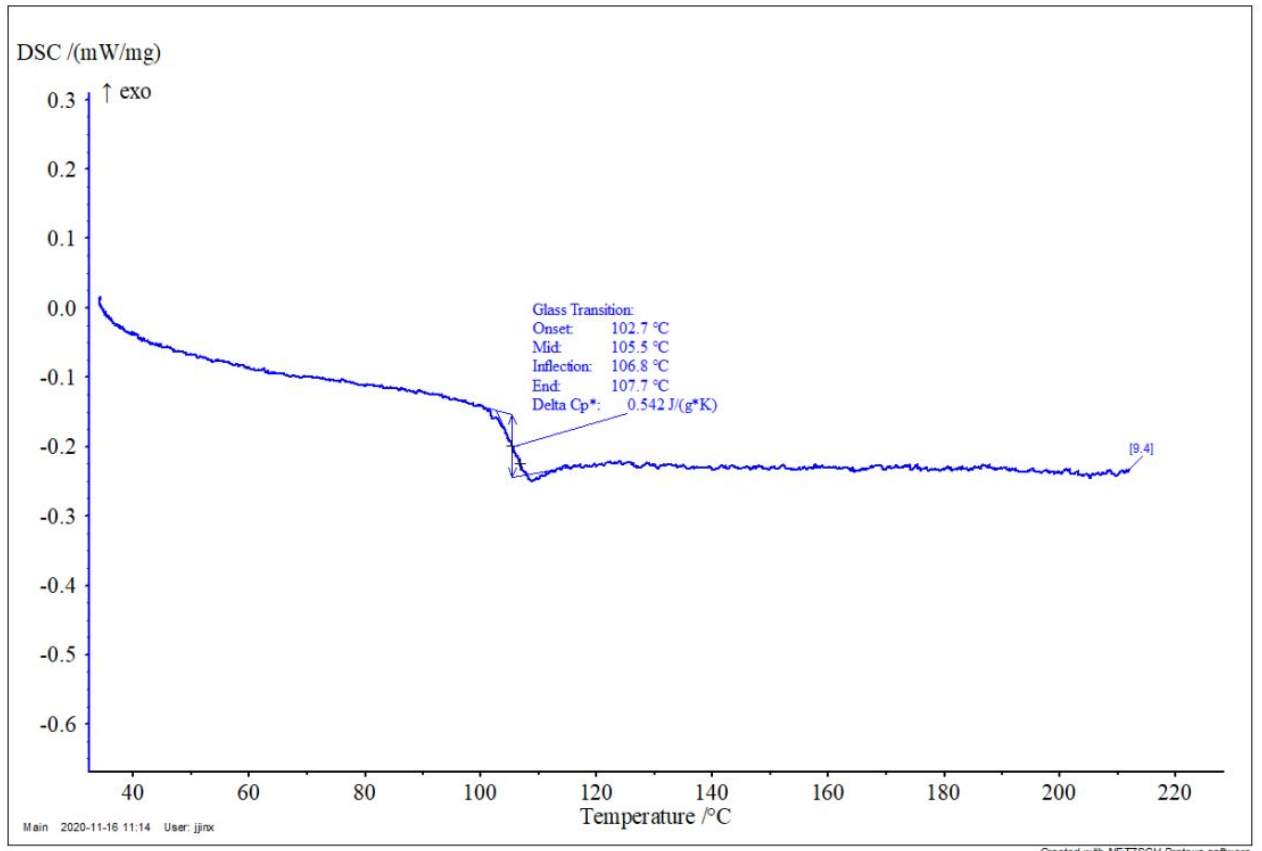

Figure S61. DSC second heating scan curves of diblock PMA-100D-b-100L. (Table2, entry 3). $T_{\mathrm{g}}=106{ }^{\circ} \mathrm{C}$.

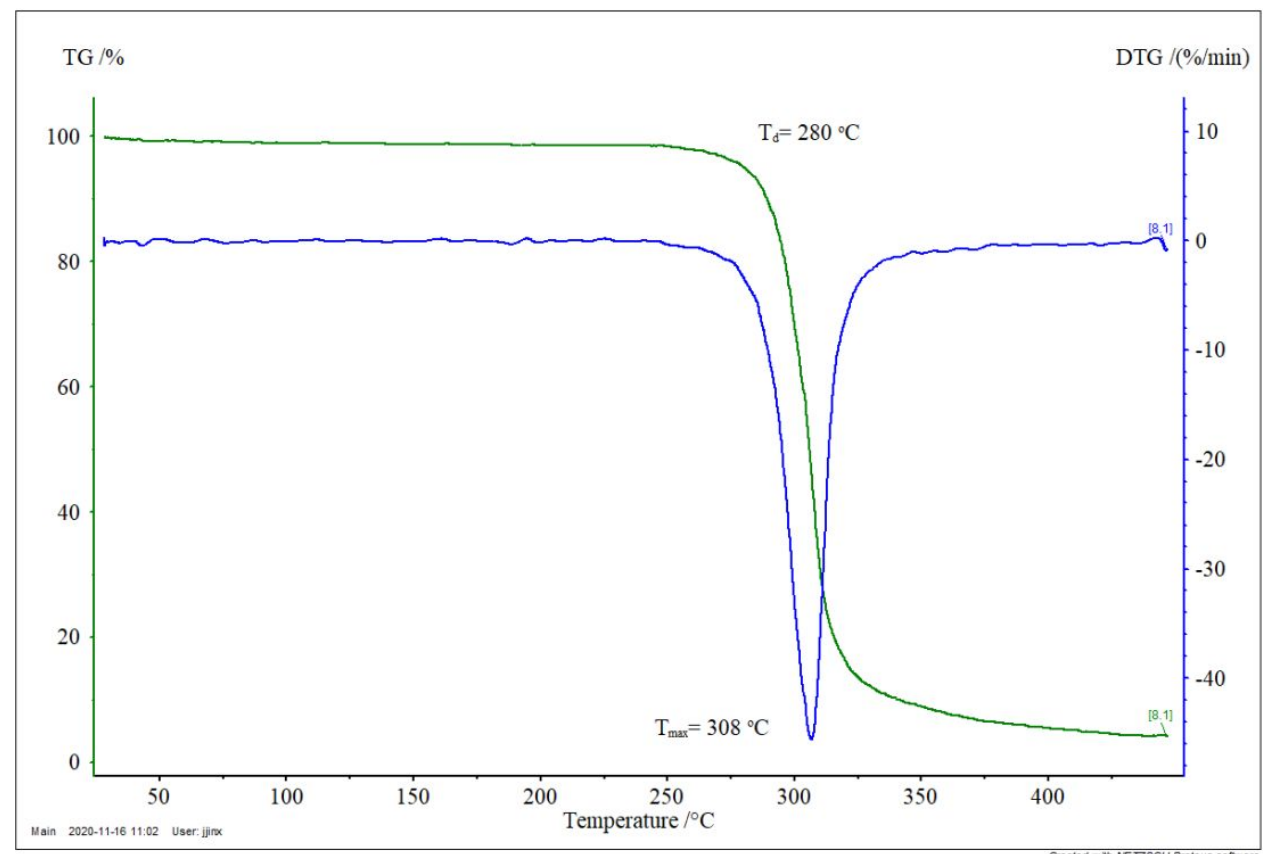

Figure S62. TGA curve of diblock PMA-100D-b-100L. (Table2, entry 3). $T_{\mathrm{d}}(5 \%)=280{ }^{\circ} \mathrm{C}, T_{\max }=308^{\circ} \mathrm{C}$. 


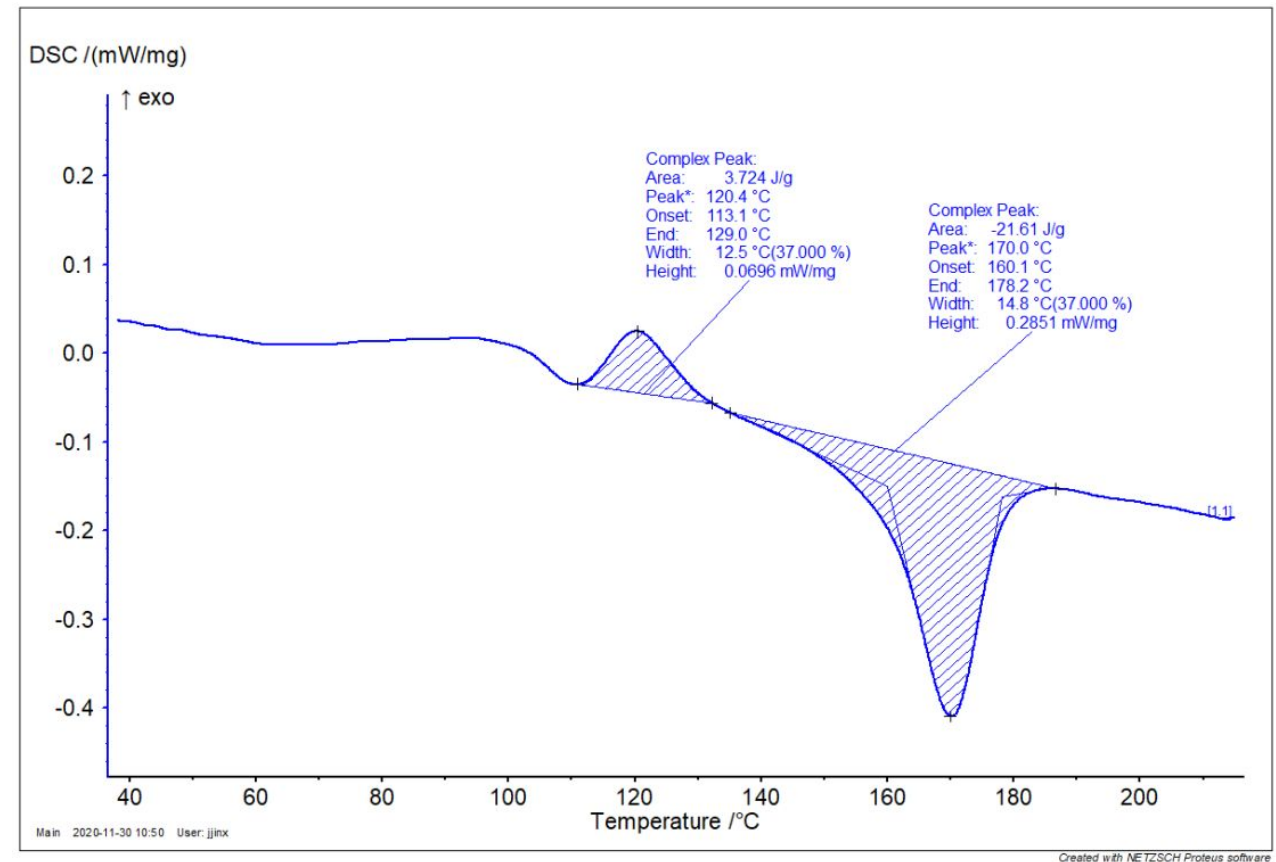

Figure S63. DSC first heating scan curves of triblock PMA-50D-b-50L-50D. (Table2, entry 4). $T_{\mathrm{c}}=120^{\circ} \mathrm{C}$, $T_{\mathrm{m}}=170^{\circ} \mathrm{C}$.

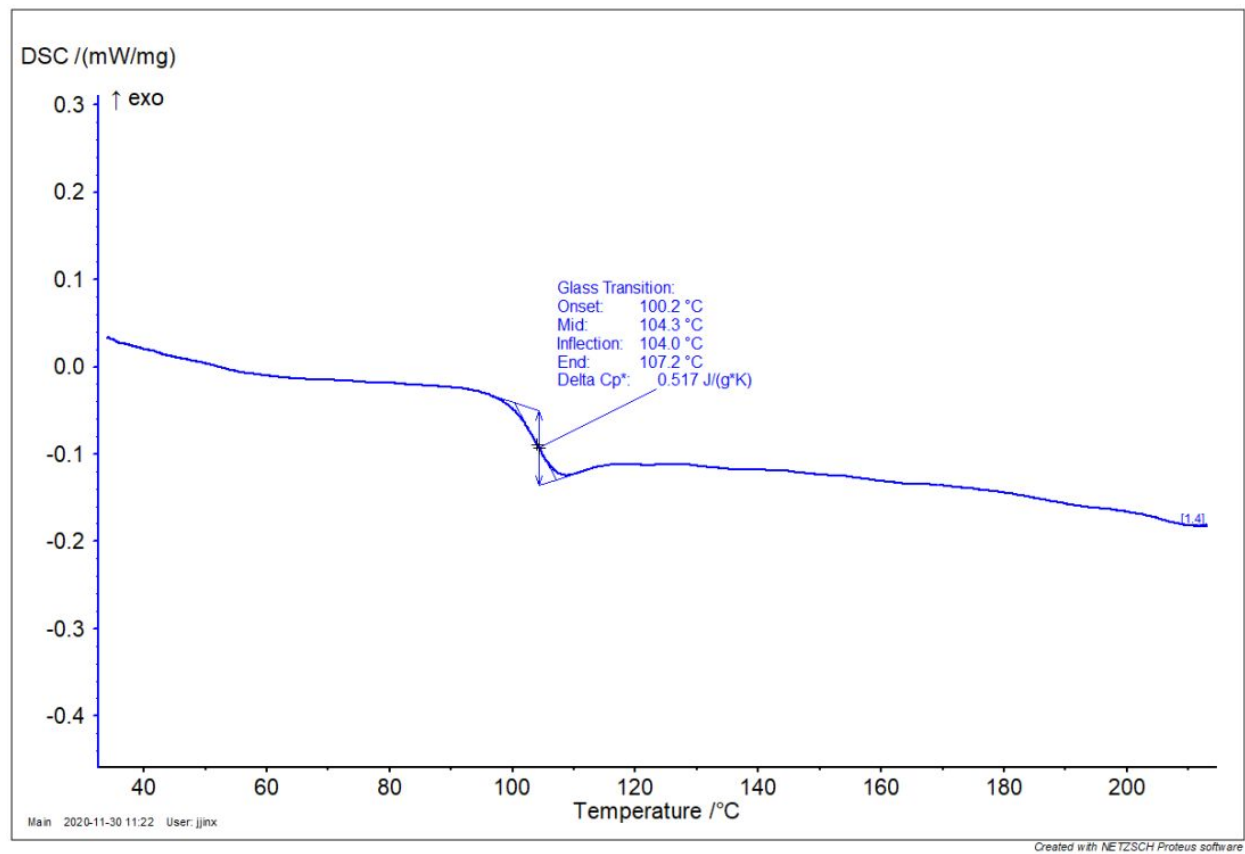

Figure S64. DSC second heating scan curves of triblock PMA-50D-b-50L-50D. (Table2, entry 4). $T_{\mathrm{g}}=104$ ${ }^{\circ} \mathrm{C}$. 


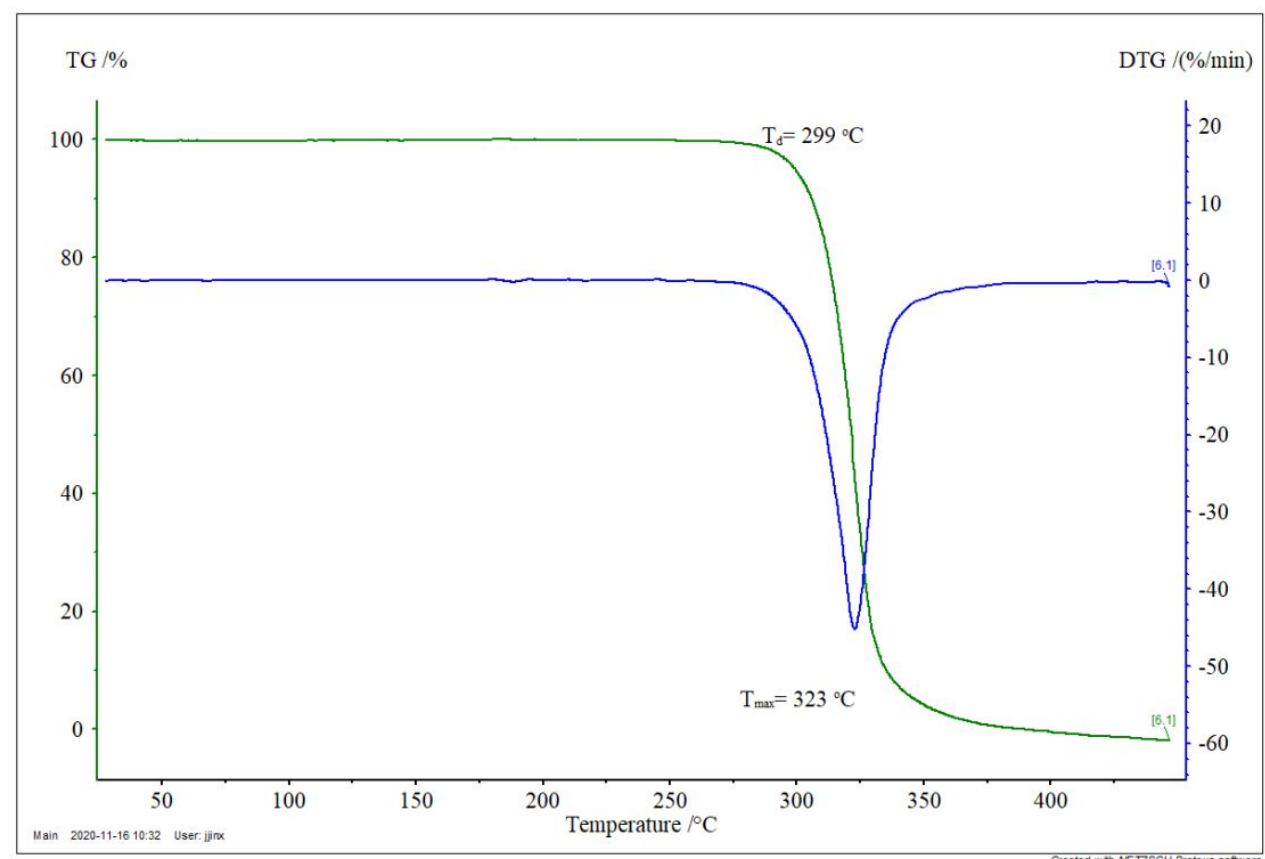

Figure S65. TGA curve of triblock PMA-50D-b-50L-50D. (Table2, entry 4). $T_{\mathrm{d}}(5 \%)=299{ }^{\circ} \mathrm{C}, T_{\max }=323$ ${ }^{\circ} \mathrm{C}$.

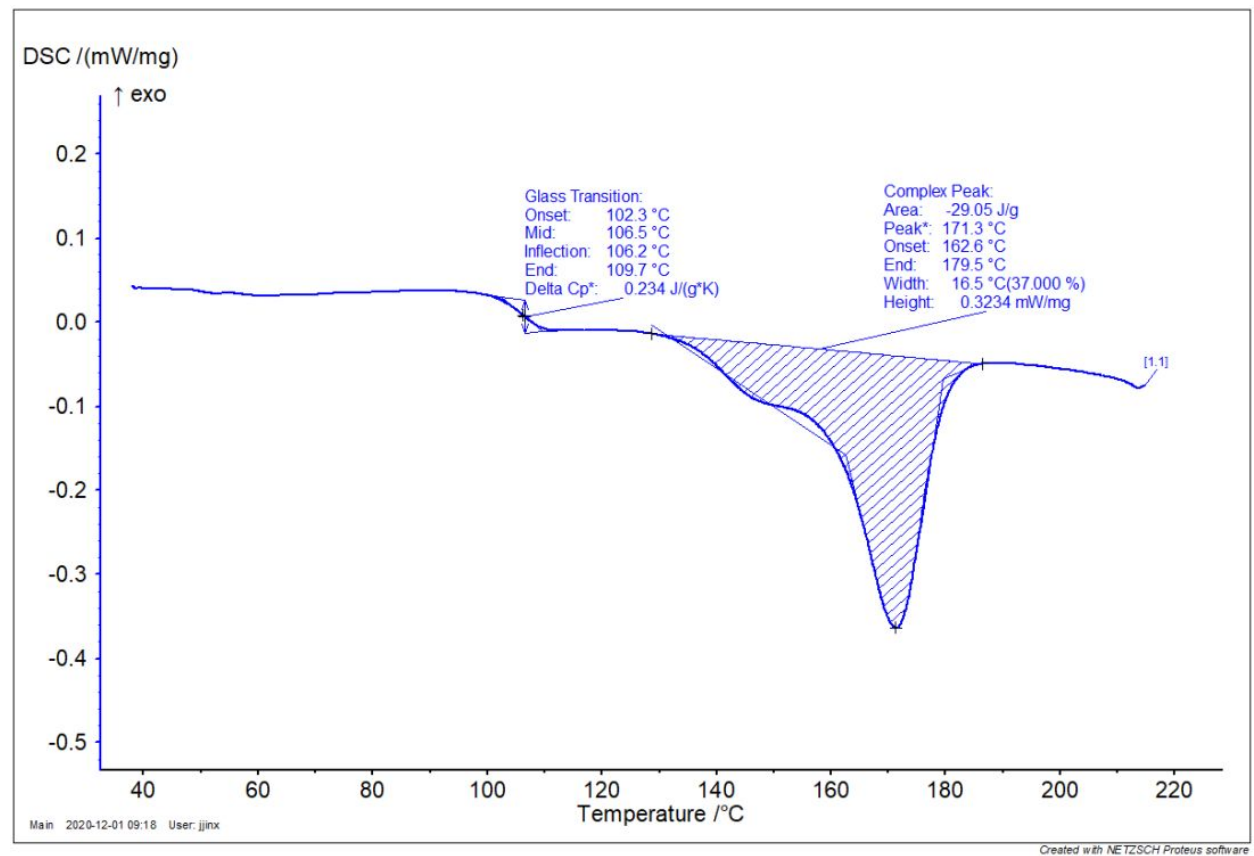

Figure S66. DSC first heating scan curves of triblock PMA-50D-b-50L-50D after isothermal crystallized for $5 \mathrm{~h}$ at $120^{\circ} \mathrm{C}$. (Table2, entry 4). $T_{\mathrm{g}}=106.5^{\circ} \mathrm{C}, T_{\mathrm{m}}=171.3^{\circ} \mathrm{C}$.

Table S3. The thermal analysis of various PMA-type.

\begin{tabular}{|c|c|c|c|c|c|}
\hline PMA-type & $T_{\mathrm{m}}\left({ }^{\circ} \mathrm{C}\right)$ & $T_{\mathrm{g}}\left({ }^{\circ} \mathrm{C}\right)$ & $T_{\mathrm{c}}\left({ }^{\circ} \mathrm{C}\right)$ & $\Delta H_{\mathrm{m}}(\mathrm{J} / \mathrm{g})$ & $T_{\mathrm{d}}\left({ }^{\circ} \mathrm{C}\right)$ \\
\hline $50 \mathrm{~L}$ & 190 & 101 & & 50 & 297 \\
\hline $100 \mathrm{~L}$ & 182 & 106 & & 24 & 295 \\
\hline
\end{tabular}




\begin{tabular}{|c|c|c|c|c|c|}
\hline $200 \mathrm{~L}$ & 178 & 107 & & 20 & 301 \\
\hline $300 \mathrm{~L}$ & 179 & 108 & & 14 & 288 \\
\hline $50 \mathrm{D}-\mathrm{b}-50 \mathrm{~L}$ & 178 & 103 & 118 & 38 & 285 \\
\hline 50L-b-50D & 178 & 104 & 121 & 30 & 289 \\
\hline \begin{tabular}{c}
$100 \mathrm{D} / 100 \mathrm{~L}$ \\
\hline $\begin{array}{c}\text { 100D-b-10 } \\
\text { 0L }\end{array}$
\end{tabular} & 185 & 103 & 118 & 28 & 285 \\
\hline $\begin{array}{c}50 \mathrm{D}-\mathrm{b}-50 \mathrm{~L} \\
-\mathrm{b}-50 \mathrm{D}\end{array}$ & 170 & 104 & 120 & 22 & 299 \\
\hline
\end{tabular}




\section{REFERENCES}

(1) Tang, L.; Deng, L. Dynamic Kinetic Resolution via Dual-Function Catalysis of Modified Cinchona Alkaloids: Asymmetric Synthesis of a-Hydroxy Carboxylic Acids. J. Am. Chem. Soc. 2002, 124, $2870-2871$.

(2) Cepanec, I.; Mikuldaš, H.; Vinković, V. An Improved Method for Synthesis of Jacobsen's Catalyst. Synth. Commun. 2001, 31, 2913-2919.

(3) Tuskaev, V. A.; Gagieva, S. C.; Kurmaev, D. A.; Fedyanin, I. V.; Zubkevich, S. V.; Bulychev, B. M. New Titanium(IV) Coordination Compounds with 2-Hydroxybenzyl Alcohol Derivatives Used in the Preparation of Ultra-High Molecular Weight Polyethylene. Russ.Chem.Bull., Int.Ed. 2018, 67, 377-381.

(4) Reimer, V.; Spaniol, T. P.; Okuda, J.; Ebeling, H.; Tuchbreiter, A.; Mülhaupt, R. Titanium and Zirconium Complexes that Contain a Tridentate Bis(phenolato) Ligand of the [OOO]-Type. Inorg. Chim. Acta 2003, 345, 221-227.

(5) Huang, Y.; Wang, W.; Lin, C. C.; Blake, M. P.; Clark, L.; Schwarz, A. D.; Mountford, P. Potassium, Zinc, and Magnesium Complexes of a Bulky OOO-Tridentate Bis(phenolate) Ligand: Synthesis, Structures, and Studies of Cyclic Ester Polymerisation. Dalton Trans. 2013, 42, 9313-9324. 